\title{
$D R_{1}|5|$
}

\section{Survey of Solar Thermal Test Facilities}

Keith Masterson

MASTER
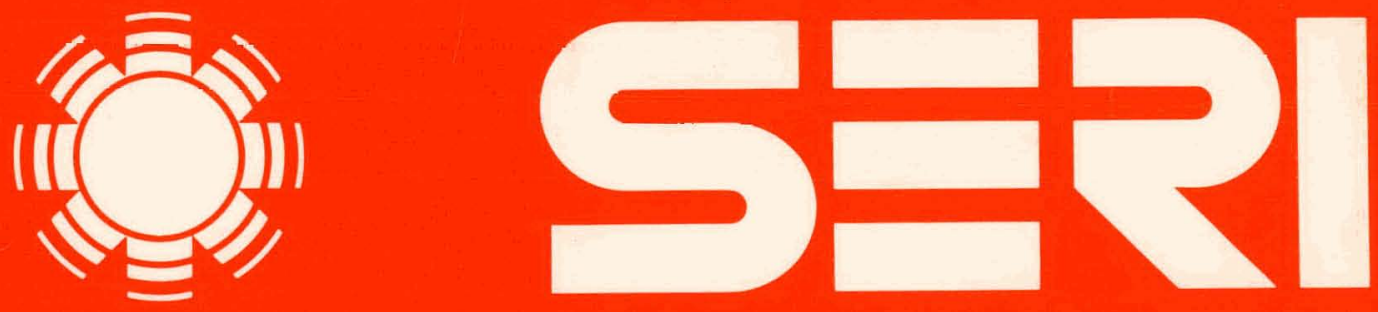

Solar Energy Research Institute A Division of Midwest Research Institute

1536 Cole Boulevard

Golden, Colorado 80401

Operated for the U.S. Department of Energy under Contract No. EG-77-C-01-4042

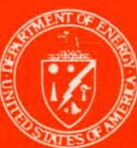




\section{DISCLAIMER}

This report was prepared as an account of work sponsored by an agency of the United States Government. Neither the United States Government nor any agency Thereof, nor any of their employees, makes any warranty, express or implied, or assumes any legal liability or responsibility for the accuracy, completeness, or usefulness of any information, apparatus, product, or process disclosed, or represents that its use would not infringe privately owned rights. Reference herein to any specific commercial product, process, or service by trade name, trademark, manufacturer, or otherwise does not necessarily constitute or imply its endorsement, recommendation, or favoring by the United States Government or any agency thereof. The views and opinions of authors expressed herein do not necessarily state or reflect those of the United States Government or any agency thereof. 


\section{DISCLAIMER}

Portions of this document may be illegible in electronic image products. Images are produced from the best available original document. 
Printed in the United States of America

Available from:

National Technical Information Service

U.S. Department of Commerce

5285 Pnrt Rnyal Rnar

Springfield, VA 22161

Price:

Microfiche $\$ 3.00$

Printed Copy $\$ 7.25$

\section{NOTICE}

This report was prepared as an account of work sponsored by the United States Government. Neither the United States nor the United States Department of Energy, nor any of their employees, nor any of their contractors, subcontractors, or their employees, makes any warranty, express or implied, or assumes any legal liabiitty or responsibility for the accuracy, completeness or usefulness of any information, apparatus, product or process disclosed, or represents that its use would not infringe privately owned rights. 
SER I /TR-34-083

UC CATEGORY: UC-59B,62,63C

SURVEY OF SOLAR THERMAL

TEST FACILITIES

KEITH MASTERSON

AUGUST 1979

This report was prepared as an account of work

sponsored by the United States Government. Neither the

United States nor the United States Depariment of

Energy, nor any of their employees, nor any of their

contractors, subcontractors, or their employees, makes

any warrañty; express or implied, of assumes any legal

tiability or responsibility for the accuracy, completeness

or usefulness of any information, apparatus, product or

process disclosed, or represents liat its use would not

infringe privately owned rights.

\section{Solar Energy Research Institute}

1536 Cole Boulevard

Golden, Colorado 80401

A Division of Midwest Research Institute

Prepared for the U.S. Department of Energy

Contract No. EG.77.C.01·4042 
THIS PAGE

\section{WAS INTENTIONALLY LEFT BLANK}




\section{FOREWORD}

This report documents efforts on SERI Task 3405, to "Conduct High Temperature Solar Research," from January l, 1978 to December 31, 1978.

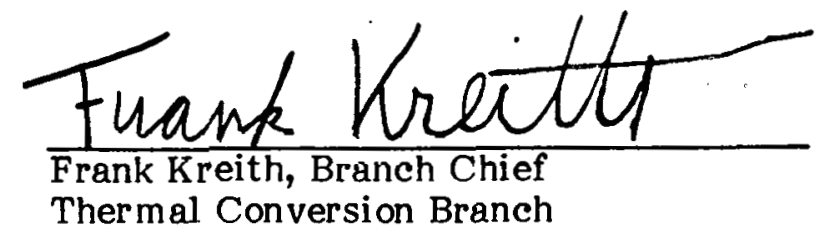

Approved for:

SOLAR ENERGY RESEARCH INSTITUTE

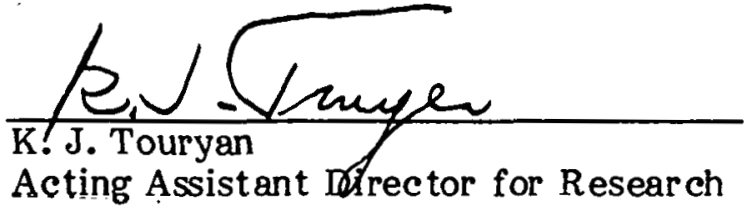




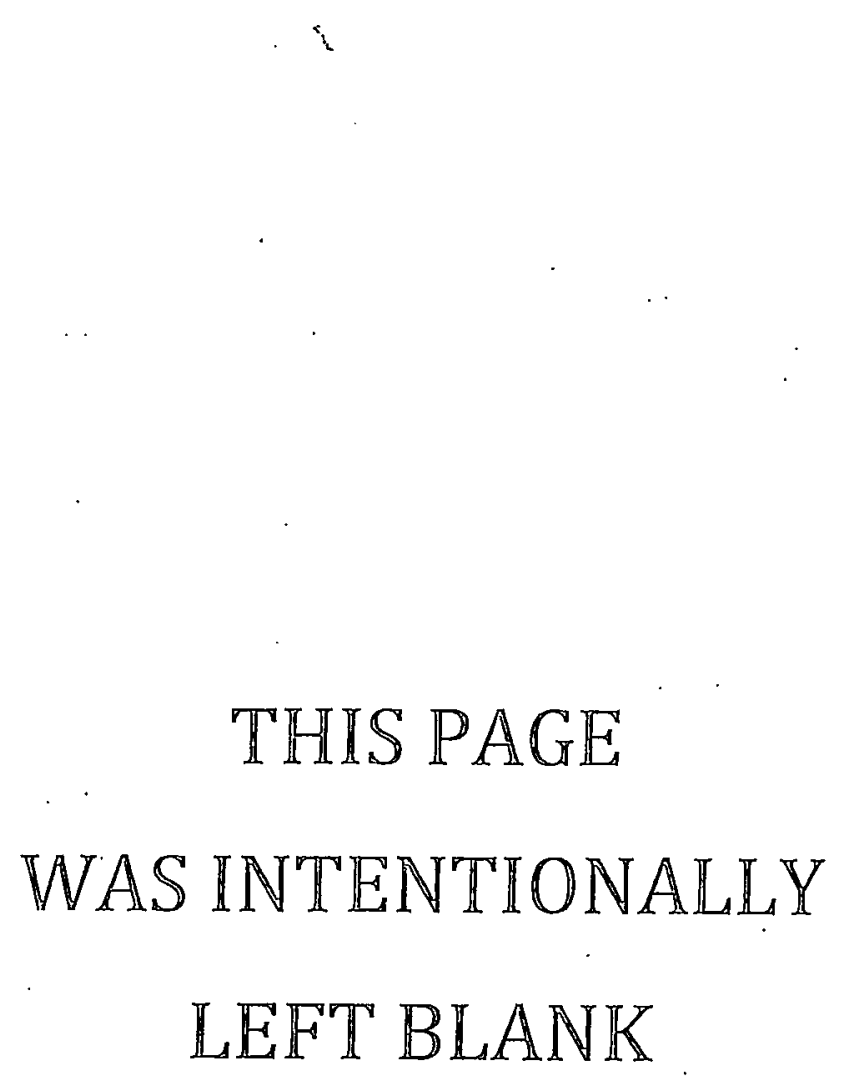




\section{SUMMARY}

In order to successfully commercialize the application of solar energy to terrestrial energy demands, the performance and durability of the solar components and systems need to be demonstrated to the buying public and their financial supporters. Thus an extensive program of hardware development and testing is required.

This final report surveys U.S. solar thermal test facilities and some foreign high-temperature test facilities that will play significant roles in developing solar thermal systems. Although the emphasis is on mid- and high-temperature technologies using concentrating collectors, a brief list of facilities qualified to test flat-plate collectors is also included. A 1975 survey of facilities by the Aerospace Corporation is frequently referenced and the complete report is incorporated as an appendix.

Seventeen facilities within the United States have capabilities for testing nonconcentrating collectors. Most of these can meet the requirements of American Society of Heating, Refrigerating, and Air Conditioning (ASHRAE) 93-77.

The present DOE program requiring concentrating collector technology and its supporting test needs is examined. Ten facilities, mostly located at national laboratories, either already exist or are planned to support the distributed concentrating collector program. In view of anticipated test needs for the program, it is recommended that all facilities except one should receive continued support and be maximally developed. It is also suggested that several facilities that are potentially useful for testing concentrating collectors should not be upgraded for that purpose.

Test requirements for central receiver technology are also identified: three existing facilities and one planned domestic facility provide support to this technology for the near future. The $5 \mathrm{MW}_{t}$ Central Receiver Test Facility at Albuquerque, New Mex., and the $400 \mathrm{~kW}$ Advanced Components Test Facility at Atlanta, Ga., are the principal installations. Since installations are expensive, additional large facilities cannot be justified. Also, seven foreign facilities can be applied toward testing receiver components or toward high-temperature metallurgy. Large-scale experiments such as the Barstow, Calif., and the planned Ft. Hood, Tex., installations will provide additional system and component testing and evaluation. For some time, surcessive generations of central receiver systems will be improved because of user experience.

Appendices containing specific data on each distributed concentrating collector and central receiver facility are included in the report. 
THIS PAGE

\section{WAS INTENTIONALLY LEFT BLANK}


1.0 Introduction $\ldots \ldots \ldots \ldots \ldots \ldots \ldots \ldots \ldots \ldots \ldots \ldots \ldots \ldots \ldots \ldots, 1$

2.0 Nonconcentrating Collectors $\ldots \ldots \ldots \ldots \ldots \ldots \ldots \ldots \ldots \ldots \ldots \ldots, 3$

3.0 Distributed Concentrating Collectors $\ldots \ldots \ldots \ldots \ldots \ldots \ldots \ldots \ldots \ldots, 7$

3.1 Present Program $\ldots \ldots \ldots \ldots \ldots \ldots \ldots \ldots \ldots \ldots \ldots \ldots \ldots \ldots \ldots, 7$

3.2 Perceived Test Needs $. . \ldots \ldots \ldots \ldots \ldots \ldots \ldots \ldots \ldots \ldots \ldots \ldots, \ldots$

3.3 Presently Available Facilities $\ldots \ldots \ldots \ldots \ldots \ldots \ldots \ldots \ldots \ldots \ldots, 10$

3.4 Conclusions and Recommendations $\ldots \ldots \ldots \ldots \ldots \ldots \ldots \ldots \ldots, 13$

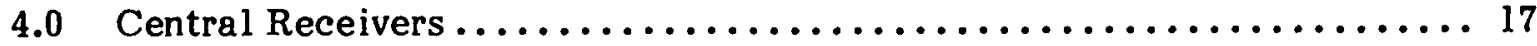

4.1 Present Program and Perceived Test Needs ................. 17

4.2 Presently Available Facilities $\ldots \ldots \ldots \ldots \ldots \ldots \ldots \ldots \ldots \ldots \ldots, 18$

4.3 Conclusions and Recommendations $\ldots \ldots \ldots \ldots \ldots \ldots \ldots \ldots \ldots . \ldots \ldots$

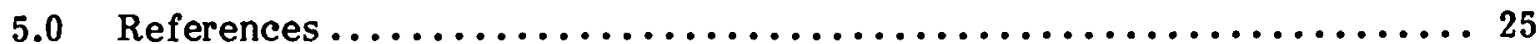

Appendix A: Data Sheets for Survey of Solar Thermal Test Facilities

Concentrating Collector .............................

Appendix B: $\quad$ Data on Central Receiver Test Facilities ..................

Appendix C: Central Receiver Solar Thermal Power System: Review and Summary of Available Test Facilities [Aerospace Corp.

Report ATR-75(7379)-2 Jan. 1975] .......................

\section{IIST OF FIGURES}

3-1 Capability of Existing or Planned Facilities in Meeting Objectives ........ 15

\section{LIST OF TABLES}

2-1 Laboratories for Commercial Testing of Nonconcentrating Collectors ....... 4

3-1 Programs Involving Distributed Concentrating Collectors ............. 8

3-2 Objectives of Test Facilities $\ldots \ldots \ldots \ldots \ldots \ldots \ldots \ldots \ldots \ldots \ldots \ldots \ldots \ldots \ldots$

4-1 Test Needs for Central Receiver Systems..................... 18 


\section{SECTION 1.0}

\section{INTRODUCTION}

This final report presents a survey of the solar thermal test facilities, a task that was carried out by Solar Energy Research Institute (SERI) at the request of the Department of Energy (DOE). The major emphasis was on mid- and high-temperature conversion technologies using concentrating collectors. However, a list of facilities capable of testing flat-plate collectors has also been included for completeness. The mid- and hightemperature technologies have been grouped and are discussed in terms of distributed and central receiver facilities.

In 1975 the Aerospace Corporation [1] completed a survey of facilities then available for testing technologies associated with the central receiver concept. In an effort to avoid duplication it has been referenced throughout this report, with a copy included as Appendix C.

Appendix A contains detailed data sheets that were completed for facilities identified as being suitable for testing concentrating collectors in distributed systems. Appendix B includes detailed specifications for recently completed facilities that were installed for testing central receiver components and components of advanced technology conversion schemes. Among them are the 5-MW test facility at Sandia Laboratories, Albuquerque, N.Mex., and the Advanced Technology Components Test Facility at Georgia Institute of Technology, Atlanta, Ga.

The direct application of solar energy to fill terrestrial energy demands has been limited by high capital cost, uncertainties in performance of currently available collectors and projected collector designs, and the low cost of more conventional energy sources. An extensive program of collector testing and evaluation is essential to remove many of these uncertainties before public or industrial investments lead to the fulfillment of DOE's plan to commercialize solar energy. Although considerable progress has been made in testing and evaluating flat-plate collector performance for low-temperature applications such as domestic water and space heating, many uncertainties remain in the performance of concentrating collectors for mid- and high-temperature applications. Very few data are available on the lifetime of collectors or their performance degradation under field use. The application of data from accelerated lifetime testing done in the laboratory to the prediction of actual performance under field use has not been demonstrated and, at present, remains a difficult and inaccurate estimate. At best, it serves as an interim technique until long-term field tests and experience can be accumulated.

Testing programs of the magnitude necessary to remove these uncertainties are expensive. The expense is greater than individual manufacturers are willing, or of ten capable, of accepting. To fill this need and support the eventual commercialization of solar energy systems, the Federal Government has established several test facilities at sites across the nation. One objective of this report is to survey the capabilities of these facilities and to determine to what extent they answer the testing needs of the national solar energy program. 


\section{SEPI}




\section{SECTION 2.0}

\section{NONCONCENTRATING COLLECTORS}

During the initial survey of test facilities, several government laboratories were identified as having the capability of testing flat-plate collectors to support lowtemperature solar thermal programs. The laboratories identified were: Brookhaven National Laboratories and Lawrence Berkeley Laboratories of DOE; National Bureau of Standards (NBS) in Maryland; and National Aeronautics and Space Administration (NASA) Laboratories at the Lewis, Langley, and Marshall sites. Each serves a different area of the program. A synopsis of the capabilities of each facility is given here. More specific data are available from the data sheets included as Appendix A.

Brookhaven National Laboratories has the capability for testing small areas of lowtemperature, inexpensive collectors suitable for boosting heat-pump performance.

Lawrence Berkeley Laboratories has a test bed [2] with approximately $40 \mathrm{~m}^{2}$ of flatplate collector. It could support the development of control strategies for heating and cooling systems that use microprocessor programs and that can be implemented in ROM memory chips for mass production. It is also supporting the development of ammonia absorption cycle chillers capable of operating with low-temperature feedwater.

National Bureau of Standards Laboratory has test loops designed for testing small areas of flat-plate collectors in order to develop and standardize testing procedures. Their test results are used in establishing accepted test procedures such as those endorsed by American Society for Testing Materials (ASTM).

NASA/Lewis has a radiant heat facility with limited $1.2 \mathrm{~m}$ by $1.2 \mathrm{~m}$ aperture. It is a general-purpose facility and has been used to characterize flat-plate collector performance under a variety of closely controlled input conditions, such as collector tilt angles and sun incidence angles $[3,4]$.

NASA/Langley has a large array (total $1,300 \mathrm{~m}^{2}$ ) of flat-plate collectors that supplies heating and cooling to a $5,000 \mathrm{~m}^{2}$ building and operates with near-ambient pressure water as a transfer fluid. Since the installation was originally designed as a collector test bed, it is well-instrumented. At present, there are collectors from five manufacturers installed on which data on individual collector performance are being taken continuously. However, because of lack of funding, the collectors are not being used for detailed studies of system performance.

NASA/Marshall has a large facility [5] established under the heating and cooling program that is intended for the evaluation of heating and cooling systems, subsystems, and selected components. It is completely committed to tests that support this program, including testing collectors from the DOE/Energy Research and Development Administration (ERDA) demonstration program. Details on this installation are given in Appendix A.

All of the facilities just described are designed and operated for research purposes. Several laboratories are capable of testing collectors commercially in accordance with the requirements of ASHRAE 93-77 [6] and Housing and Urban Development (HUD) document 4930.2 . They should serve most of the needs of commercial manufacturers of flat-plate collectors. A list of those laboratories is provided in Table 2-l. It was compiled from a HUD document [7] and a report prepared by NBS in cooperation with the Air Conditioning and Refrigeration Institute [8] . 


\section{Table 2-1. LABORATORIES FOR COMMERCIAL TESTING OF NONCONCENTRATING COLLECTORS}

Facility and Address $\quad$ Transfer Fluid

Approved Engineering Test Lab

Attn: Bob Finch or Irving Williams

15720 Ventura Blvd. Suite 608

Liquid

Encino, CA 91436

Boeing Aerospace Company

Attn: A.R. Lunde or Paul T. Sauber

Liquid and Air.

Box 3999, Mail Stop 86-01

Inside Simulator

Beattle, WA 98124

(?.ก6) $773-8.516$

Desert Sunshine Exposure Tests, Inc.

Attn: William ' $\mathrm{l}$ '. Dokus or Gene A. Zerlaut

Box 185-Black Canyon Stage

Phoenix, AZ 85020

Liquid and Air

(602) 465-7521

Florida Solar Energy Center

Attn: James Roland or Dr. Charles Beach

Liquid

300 State Road 401

Cape Canaveral, FL 32920

(305) 783-0300

Honeywell Energy Resource Center ${ }^{a}$

Honeywell Laboratories

Minneapolis, MN

Liquid, Air

Johnson Environmental and Energy Center

Research Institute

Attn: Mr. William Reid

Annex D

University of Alabama at Huntsville

Liquid

P.O. Box 1247

Huntsville, AL 35807

(205) 895-6257

Lockheed Solar Collector Test Facility

Attn: R. K. Wedel, Sr. Scientist

Dept. 52-32, Bldg. 205

Liquid

3251 Hanover Street

Palo Alto, CA 94304

(415) 493-4411 ext. 45776

${ }^{a_{T}}$ The Honeywell facility is not generally available for testing collectors from external sources. 
Table 2-1. LABORATORIES FOR COMMERCIAL TESTING OF NONCONCENTRATING COLLECTORS (Concluded)

Facility and Address

Transfer Fluid

New Mexico State University

Physical Science Laboratory

Attn: Mr. William Stevens

Las Cruces, NM 88003

Liquid and Air

(505) 522-4400

University of Connecticut

Solar Energy Evaluation Center

Attn: David R. Jackson,

Acting Director

U-Box 139

Storrs, CT 06268

(203) 486-2090

Solar Energy and Energy

Conservation Laboratory

Attn: C.A. Morrison

Mechanical Engineering Department

Liquid

University of Florida

Gainesville, FL 32611

(904) 392-0818

Wyle Laboratories

Attn: David Reese

Box 1008

Huntsville, AL 35807

Liquid and Air

(205) 837-4411

Liquid and Air 


\section{SEPI}




\section{SECTION 3.0 \\ DISTRIBUTED CONCENTRATING COLLECTORS}

In the collection of solar energy, tracking concentrating systems have the capability of attaining higher temperatures, lower losses, and greater annual energy production than flat collectors whenever a large percentage of the yearly insolation is under clear sky conditions. In many cases the use of concentrating collectors is the only method of obtaining the high temperatures necessary for many industrial process upplications. Recent studies $[9,10,11]$ covering such applications indicate that, given favorable economic climates and political backing, a substantial area of distributed concentrating collector systems will eventually be required.

For systems utilizing heat engines to generate shaft power, concentrating collectors are necessary to achieve sufficiently high temperatures to give acceptable overall thermodynamic efficiency. Total energy systems, irrigation pumps, and many dispersed power systems all require shaft power and therefore undoubtedly will use some form of distributed concentrating collectors if they are to be powered by the sun. In most large buildings cooling loads are equal to or greater than heating loads. To date, flat-plate collectors are marginal in their ability to provide working fluids at temperatures which ensure reliable operation of absorption cycle chillers, and they can drive Rankine cycle units only at low efficiencies. Therefore, in most applications of solar energy to air conditioning systems, it appears that concentrating collector systems will be most economical. In fact, recent studies $[12,13]$ indicate that a parabolic trough will deliver a greater annual energy output than an optimum tilted flat-plate collector for a wide variety of climatic conditions. However, because of their closer compliance with common building practices and techniques, flat-plate devices now represent the majority of the solar collector market. As concentrating collector technology advances and operating data document their performance, one would expect them to have a substantial role in future solar energy markets. However, thorough understanding and documentation of the performance of concentrating collectors under actual operating loads and insolation conditions are prerequisite to their widespread acceptance.

\subsection{PRESENT PROGRAM}

Within the Division of Solar Technology the main objective of the current program for distributed solar energy systems using concentrating collectors is to establish the technical and economic feasibility of the concept [14. The program is outlined in Table 3-1, with additional details given in the text that follows. As part of this effort DOE is funding development of several systems that require shaft pnwer. These projects are the Solar Total Energy (STE) and the irrigation projects managed by Sandia Albuquerque and the small power systems project managed by Jet Propulsion Laboratory (JPL).

In the irrigation project a large-scale experiment has been constructed for a shallow-well pumping station near Willard, N. Mex,, and a deep-well system near Coolidge, Ariz., is being built. For these projects the government has simply procured concentrating collectors from the commercial market. Collector design and testing were not explicitly

supported but were left to the rnmmercial sector. The support afforded by these procurements is expected to stimulate commercial production of concentrating collectors. 
Table 3-1. PROGRAMS INVOLVING DISTRIBUTED CONCENTRATING COLLECTORS

\section{Applications}

Shaft Power/Electricity

Irrigation

Small Power Systems

Rankine Cycle Cooling

Heat

Industrial Process Heat

Absorptionin Cyule Conoling

Combined

Snlar Total Energy

Storage Subsystems Studies

Technology Development

Collector Hardware Development

Collector Peak Performance

Performance Standardization

Storage

Long-Term Degradation

In the solar total energy program there are twn large-ssale exporimento underway. Oıt is to supply energy to military barracks at Fort Hood, Tex., and the other is to supply heat and electricity to a commercial textile plant in Georgia. Unlike the irrigation project, however, DOE has supported development of advanced collector concepts for solar total energy applications by contracts with General Atomics, General Electric, McDonnell-Douglas, Sheldahl, and Raytheon.

In support of the solar total energy program, DOE has funded a test facility at Sandia Laboratories in Albuquerque, N. Mex. The mission of this facility is to verify system concepts and test component hardware while providing power, heat, and cooling to a $1,200 \mathrm{~m}^{2}$ office building. Also included is a facility to measure separately the efficiency of collector modules as a function of flow rate and temperature.

The distributed power systems program initiated by JPL is exploring some collectorreceiver combinations that might be used for electric power production. Total energy is not being considered at JPL; instead, emphasis is placed on obtaining high temperatures in order to achieve high thermal efficiencies. As part of this program, JPL is developing technology for point focus distributed systems. Basic systems studies are being done, with all subsystem work on concentrators, receivers, and prime movers subcontracted to industry. JPL is planning to upgrade an existing facility at Edwards Air Force Base to test and evaluate hardware. 
The application of distributed concentrating collectors to heating and cooling loads was addressed by a recent round of Request for Proposals (RFP) and Program Research and Development Announcements (PRDA) issued by DOE/ERDA [14,15] and administered by the Albuquerque Operations Office. The existence of, or the need for, test facilities was not mentioned in the documents. Several installations of concentrating collectors for air conditioning applications have been made by enterprising companies, but little useful data on their actual performance are available.

The application of the solar total energy concept to industrial needs using distributed concentrating collectors is under study through contracts recently let to McDonnellDouglas and Atomies International by Sandia [14].

The potential market of solar energy for industrial process heat has been analyzed in several reports $[9,10,11]$ with conflicting results. Many of the uncertainties in these results are due to the present lack of technical knowledge of process heat system performance and of the life-cycle cost of appropriate concentrating collectors; i.e., data input to the models.

\subsection{PERCEIVED TEST NEEDS}

To develop distributed concentrating collector systems, several kinds of testing and optimization studies are required. Component design, testing, and performance evaluation, system design, and system integration are all related in an iterative process. Long-term performance data on systems should be generated under operating conditions and should be thoroughly documented to obtain reliable life-cycle costs. Different systems need to be compared for operating and control strategies and under a variety of insolation and load conditions before appropriate choices and sizing can be engineered for commercial installations. In general, the capital outlay and effort to develop test facilities with the required versatility and extensive instrumentation cannot be justified by most collector manufacturers or commercial engineering firms.

Industry is reluctant to invest the large venture capital necessary to install solar energy systems to supply part of plant energy needs. This is especially true in the absence of well-documented operating, maintenance, and performance data on which life-cycle costing can be based. The availability for inspection and trial operation of facilities with hardware simulating anticipated industrial applications should be effective in persuading the commercial sector to utilize the solar resource.

The principal objectives of test facilities for distributed collector systems are given in Table 3-2. 


\section{Table 3.2 OBJECTIVES OF TEST FACILITIPS}

Test and document the thermal performance of subsystems under standard, well-defined, steady-state operating conditions in order to aid research in advanced technologies

Develop standardized procedures for testing subsystems under a variety of operating conditions

Validate analytical models for system performance

Accumulate and document operating and maintenanco expcricnce in order tu assess system reliability, lifetimes, and life-cycle costs

Identify problems and/or areas for improvement in hardware that would aid the commercial sector

Operate integrated systems under a variety of loads and insolation in order to develop optimum operating strategies for various commercial applications.

Stimulate industrial solar utilization by being available for inspection, trial operation, and operator training

\subsection{PRESENTLY AVAILABLE FACIITIES}

Several test facilities that could be used or adapted to the development of single concentrators and/or distributed collector systems have been identified from the literature, meeting reports, and hy site visite. The initial list included: (1) Sandia Albuquerque's Midtemperature Solar System Test Facility, including the Collector Module Test Facility; (2) American Technological University (ATU)/Fort Hood, Tex., Solar Engineering Test Module; (3) JPL/Edwards Air Force Base point-focus, distributedreceiver technology test and evaluation site; (4) NASA/Marshall; (5) NASA/Langley; (6) NASA/Lewis; (7) Lawrence Berkeley Laboratory; (8) Argonne Laboratories; (9) University of Chicago; (10) NBS, Washington, D.C.; (11) Desert Solar Environmental Testing Inc., Ariz.; (12) Sheldahl/Suntec; and (13) General A tomic Company.

Data forms were prepared and completed in as much detail as possible for each of the listed facilities. The completed data sheets are included in Appendix A of this report.

In addition to these facilities, concentrating collector manufacturers identified from a recently published list [16] were contacted to see if they had facilities appropriate for inclusion in the survey. Three manufacturers responded to the inquiry. The capabilities reported by these manufacturers are also summarized in Appendix A. It is presumed that several of the manufacturers who did not respond have the ability to test their products but were not interested in public disclosure of their capabilities. Some foreign manufacturers such as the M.A.N. Company in West Germany are also known to have the capability to test concentrating collectors but they have not been researched for this report. 
Few of the facilities listed are appropriate for supporting large or high level research programs, especially if system performance is addressed. Except for Sandia and NASA/Marshall the facilities are small test loops meant to characterize individual collectors and have no potential for system simulation. Some of these facilities were discussed in Section 2.0. The Sheldahl test loop is no longer operational. The remainder are considered here.

The short collector-to-source distance makes radiant heat facilities, such as that available at NASA/Lewis, unusable for testing concentrating collectors of any size; the small collector size and heat handling capabilities make them inappropriate for systems testing.

At Argonne Laboratories several small portable test loops [17] were designed for performance testing of nonimaging concentrators. Some loops can be operated at temperatures as high as $150^{\circ} \mathrm{C}$ by using ethylene glycol instead of water. A high temperature loop using Therminol 66 is operational for temperatures to $260^{\circ} \mathrm{C}$. The calorimetric ratio technique is used to monitor the performance of test modules. Weather data and insolation measurements appear to be very good. Two test loops similar to those at Argonne (one for water, one for Therminol 66) are installed at the University of Chicago. The Chicago and Argonne loops are located in a hazy/cloudy climate and are potentially useful for measuring performance of focusing collectors under conditions of high circumsolar radiation.

The test loop at ATU/Ft. Hood [18] was installed to measure concentrating collector performance as part of the solar total energy large-scale experiment at that location. It can accommodate apertures to areas of approximately $40 \mathrm{~m}^{2}$. The heat is discharged into the atmosphere. Due to a change in concept for this experiment the test loop is not presently in use and would require minor repair to become operational.

Desert Solar Environmental Testing Inc. (DSET) [19] is a commercial testing firm that is interested mainly in standard thermal performance testing of individual flat-plate collectors to ASHRAE specifications. A silicone fluid loop can test two different collector modules simultaneously to temperatures of approximately $350^{\circ} \mathrm{C}$. Because no storage capability exists, the collected heat is discharged to the atmosphere by way of an evaporative cooler. The facility can handle one or two modules.

JPL has begun research on point-focusing receivers in support of a small power systems program and has established a test site using facilities existing at Edwards Air Force Base [20]. Included in the near-term plans are a 6-m dish, two $11-\mathrm{m}$ dishes to be used as test beds for receivers and engines, and six $11-\mathrm{m}$ low-cost concentrators. Operation at temperatures greater than $315^{\circ} \mathrm{C}$ with $8.6-\mathrm{MPa}$ steam or $0.31-\mathrm{MPa}$ air is anticipated. A computer-based data acquisition system is operational. The primary emphasis is on high temperatures and small heat engines for power production. In these systems the concentrator, receiver, and heat engine will form a modular unit that eventually will be tested together. A single test module is an order of magnitude too small to duplicate most industrial process heat requirements.

General Atomic Company has constructed a solar-heated test loop at San Diego, Calif., to demonstrate the operation of a eutectic salt as a heat transfer fluid. The facility uses six of the company's fixed mirror solar concentration modules and is designed to operate to $600^{\circ} \mathrm{C}$ using Dupont's Hitec ${ }^{\text {TM }}$ fluid. The test loop was constructed from commercially available stainless steel pipes and valves and uses trace heaters throughout to prevent freeze-up. Although initial project goals are expected to be met during the spring of 1979, the facility may have long-term value for component/material testing and salt loop O\&M studies in the outdoor environment of an appropriate test site. 
The NASA/Marshall installation [5] is intended to evaluate heating and cooling systems, subsystems, and selected components. The total aperture of active collectors that can be mounted is $400 \mathrm{~m}^{2}$. Present design limits on guage pressure and temperature are $1 \mathrm{MPa}$ and $120^{\circ} \mathrm{C}$. Assembled from an unused NASA test station, the facility uses an existing computer for data acquisition and control. Long runs on the analog data lines and fluid loops decrease the measured accuracy of system performance. The facility is totally committed to testing heating and cooling components, including collectors from the DOE/ERDA demonstration program. As of this writing, the facility had not completed qualification for acceptance by DOE, and its utilization was less than 25\%. Capabilities do exist for simulating collector outputs to $147 \mathrm{~kW}_{\mathrm{t}}$ and cooling and heating loads equivalent to $36 \mathrm{~kW}_{\mathrm{t}}$.

Sandia Laboratories in Albuquerque, N. Mex., maintains a Midtemperature Solar Systems Test Facility (MSSTF) that consists of two separate facilities: a Collector Module Test Facility (CMTF) [21] and a Systems Test Facility (STF) [21].

The CMTF is used to obtain thermal and optical performance data for prototype collectors of up to about $45-\mathrm{m}^{2}$ aperture. It has three separate fluid loops that can be used on three simultaneous tests. One fluid loop incorporates a turntable on which a collector module can be mounted to follow the sun. Collector modules may be tested using water up to $315^{\circ} \mathrm{C}$ or a heat transfer oil up to $425^{\circ} \mathrm{C}$. A collector test takes from four to twelve weeks.

The STF consists of solar collector fields, high- and low-temperature thermal storage facilities, an electrical power generation subsystem, a lithium-bromide absorption air conditioner, an instrumentation and control system, a weather station, and loads. The loads may be cooling towers, a turbine/generator that can produce $32 \mathrm{kWe}$ and about $200 \mathrm{kWth}$, and/or a nearby $1,100-\mathrm{m}^{2}$ office building. STF components are evaluated for potential incorporation into solar total energy dispersed solar power application projects. STF equipment can test separately or as part of a system configuration, all components and subsystems that may comprise a solar energy system in the midte mperature range $\left(200^{\circ} \mathrm{C}-425^{\circ} \mathrm{C}\right)$.

SERI intends to establish the capability for hands-on study of individual collectors, collector fields, and solar process heat systems. A field test site is under construction. A Standard Module (STAM) [22] is under construction and will be installed in the near future. It consists of a modest-sized test loop capable of handling the 25-kWt output from a maximum $40-\mathrm{m}^{2}$ aperture collector. Three test stations, any two of which can be operated simultaneously, are planned. One station is a rotating platform that can track the sun. The installation is instrumented with state-of-the-art transducers and connected to a digital data collection and processing system. Initial design is for operation using either water or Therminol 66. This equipment will provide a versatile test facility capable of testing concentrating collector performance.

Already installed at the SERI test site and referred to as the Subsystem Technology Development Facility (STDF) is a tracking paraboloidal dish concentrator with an aperture of approximately $28 \mathrm{~m}^{2}$. A second identical dish is planned for the near future. Instrumentation will be added for conducting basic research in heat transfer, fluid mechanics, materials for heat transfer and storage, and for analyzing advanced systems with capabilities leading toward commercialization of high temperature (>300 3 C) thermal conversion applications. 
Initial procurement efforts are underway at SERI as part of the development of the SERAPH (Solar Energy Research and Applications in Process Heat) field installation. SERAPH is a flexible, modular facility that will assist the engineering development of complete solar systems. Early use of the facility (to become operational in FY80) will be directed toward solar industrial process heat systems. The capgbility will exist to introduce collector field subsystems (up to approximately $500 \mathrm{~m}^{2}$ ), thermal storage devices, test articles (e.g., steam generators, chillers) and load demand, and profiles characteristic of specific industrial processes. An auxilary energy source will be available to augment field output or to simulate collector field output, representative of other geographic locations.

Two experimental systems that test distributed concentrating collectors have been developed outside of the United States. They are described briefly here, with further details available in a paper presented by J.D. Walton at the SERI Concentrating Collector Technology Symposium [23]. One of them is a plane-parabola system being developed by Hitachi, Ltd. in Tokyo [23, p.248]; it has the potential for testing operating strategies and storage subsystems as well as their unique concentrator and receiver components. It utilizes a unique configuration of 5 rows of 20 flat mirrors that track the sun and direct its radiation onto 5 parabolic trough concentrators. The concentration ratio of the quasilinear focus system is designed to be 152. Twenty of these units will be interconnected to provide a total heliostat area of $9,000 \mathrm{~m}^{2}$ with an expected output of 1.0 MW of electric power. A pilot plant using fewer modules is scheduled to begin operation in July 1980.

A tracking solar concentrator/receiver unit developed by J. L. Pierrier is located in Angers, France [24]. The unit has potential as a module in a distributed collector system and as a test bed for receiver subsystems. It consists of some 263 mirrors mounted on a frame, $8.6 \mathrm{~m}$ high by $12 \mathrm{~m}$ wide. They reflect the sun's radiation into a focal zone approximately $5 \mathrm{~m}$ in front of the plane of the concentrator and give a concentration ratio on the order of 200 . The thermal power collected by this system is approximately $50 \mathrm{~kW}$.

\subsection{CONCLUSIONS AND RECOMMENDATIONS FOR DISTRIBUTED, CONCENTRATING COLLECTOR TEST PACILITIES}

Several facilities (NASA/Lewis, NBS, Brookhaven, NASA/Langley, and LBL) presently have no capabilities for testing concentrating collectors. Some (DSET, Argonne, Ft. Hood, and Sandia CMTF) can test individual collector modules but can perform no system studies. Although any existing facility could in principle be upgraded to handle concentrating collectors at high temperatures or system studies, substantial eff ort such as adding storage and replacing piping to handle higher pressures would be required. Most existing facilities are being used extensively in support of existing DOE programs; upgrading them to handle process heat studies does not seem to be economically attractive.

Only the Marshall test facility is currently underutilized. It was designed for flat-plate collectors and low-temperature applications for heating and cooling. It would require substantial money and effort to add high temperature capabilities and instrumentation for solar process heat applications.

For the near future the Sandia facility is devoted to the support of the solar total energy program. Although it could be converted to process heat development, the present 
MSSTF would need modification to simulate a variety of industrial load applications that require high pressure water storage and the use of steam or high pressure water for heat transfer from the collector field.

None of the existing facilities is equipped to simulate a wide variety of process heat applications and to educate the industrial/commercial sector by providing "hands-on" experience appropriate to their applications. In light of industry's reluctance to invest in untested or unproven technologies, access to appropriate facilities would seem to be essential if an ambitious DOE plan to utilize the solar resource for process heat applications is to succeed. In addition, none of the existing facilities is adequate for doing basic research in heat transfer and storage technologies on a modest scale or for testing high performance receivers and systems suitable for commercial tasks in high temperature thermal conversion $\left(300^{\circ} \mathrm{C}\right)$.

The capabilities of existing and planned facilities in meeting the needs of a distributed collector program are summarized in Fig. 3-1.

From data on existing facilities and from the anticipated needs for various facilities, the following specific recommendations are made.

Sandia

JPL

SERI

ATU/Ft. Hood

General Atomic

Argonne

Univ. of Chicago

NASA/Marshall

NASA/Langley

NASA/Lew is

NBS

Brookhaven
Continue present program in total energy system development and short-term collector testing at temperatures below $300^{\circ} \mathrm{C}$.

Establish SPS (point focus) test site.

Use STDF point focus dishes for high temperature $\left(\mathrm{T}>300^{\circ} \mathrm{C}\right)$ and advanced solar energy research; install STAM test loops for standards research; establish SERAPH facility for research into solar process heat applleations.

Due to change to small central receiver design, the test loop is no longer needed. Support should be stopped and loop disassembled or moved.

Test loop is unique and should continue to be supported in the near future. However, consideration should also be given to relocating it at a national laboratory.

Continue low level support.

Should not be upgraded to handle concentrating collectors 


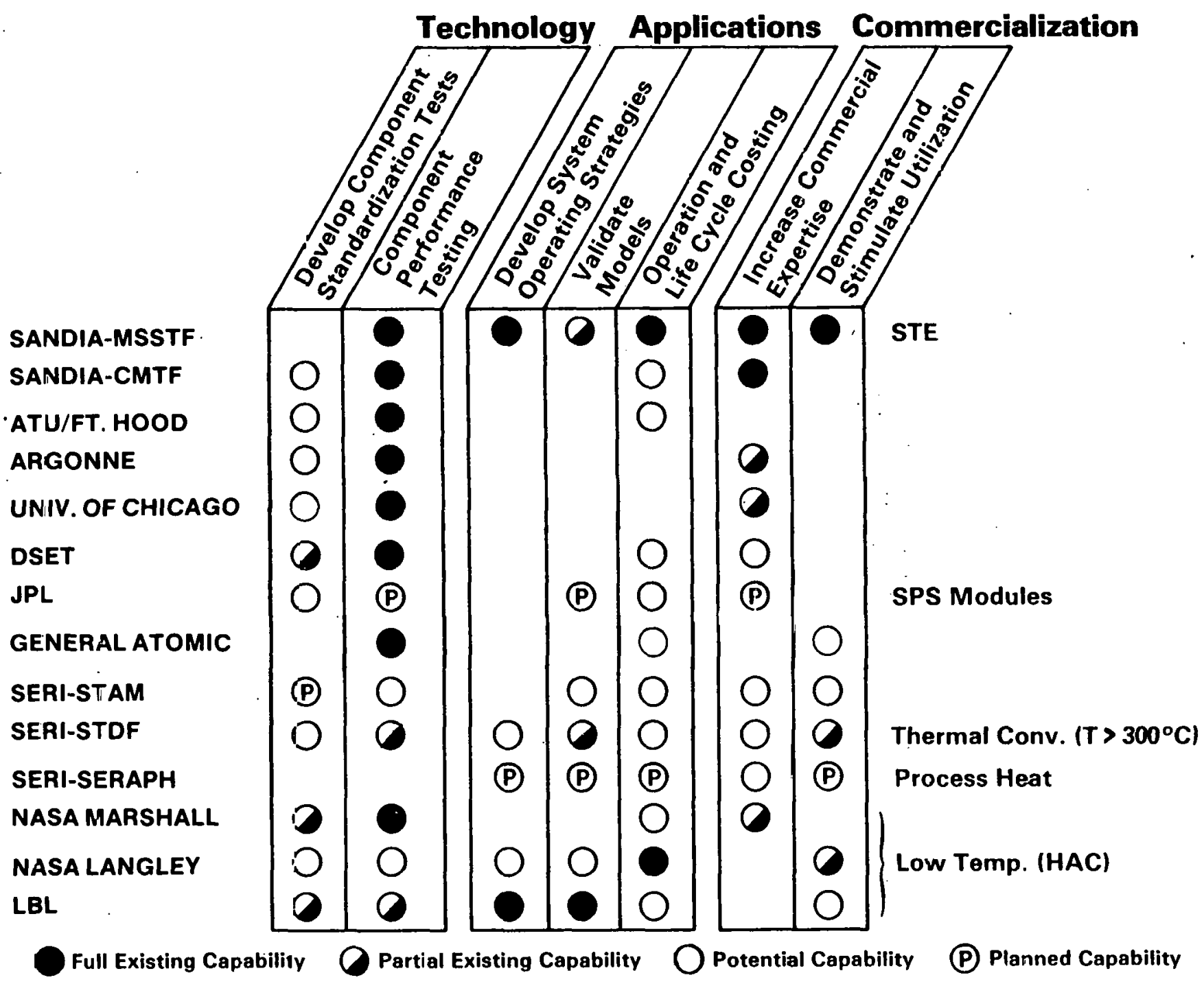

Figure 3-1. Capability of Existing or Planned Facilities in Meeting Objectives 
SEPI萧 


\section{SECTION 4.0}

\section{CENTRAL RECEIVERS}

A central receiver system has a large number of separate mirrors (heliostats), each controlled separately to reflect an image of the sun onto a fixed thermal converter or receiver. The heliostats can be controlled individually by analog or computer tracking mechanisms, or they can be ganged together for control by a common mechanism. The fixed receiver is usually located on a tall tower.

The central receiver system can be an alternative to distributed systems for producing solar thermal energy. It is attractive where further conversion to shaft power can benefit from higher temperatures and greater cycle efficiencies. Central receivers may also be necessary to provide high temperatures for certain industrial processes or to produce hydrogen for secondary fuels. Early studies indicated that the optical transmission of energy to a single receiver is more economical than thermal transmission by a working fluid as in distributed receivers [25]. Furthermore, economies of scale should be realized in plants to the 10- to 100-MW electrical size. For these reasons DOE has an active program to demonstrate the technical feasibility of central receiver systems.

\subsection{PRESENT PROGRAM AND PERCEIVED TEST NEEDS}

A present DOE program objective for central receivers [26] is to establish their economic viability as a resource for electric utilities by the mid 1980s. To accomplish this there is a near-term effort to demonstrate storage-coupled central receiver systems. A 10-MW electrical generating plant is to be operational by 1981 at Barstow, Calif; the plant will feed power into the utility grid of the Los Angeles area. Other major directions of the program are to supply heat for tertiary oil recovery and to repower existing fossil-fueled generating plants by supplementing their conventional boilers with heliostat fields and tower receivers. The first of these "solar-fossil hybrids" may begin operating in 1983.

Although the technologies are available to accomplish these goals, their economics have not been demonstrated. In fact, modification of the systems to lower the cost will probably include new or modified technologies requiring substantial testing. Examples are the low-cost heliostat development program, high-temperature Brayton cycle engines, and accompanying ceramic receivers.

More recently, an interest has emerged in applying central receiver concepts to industrial and process heat for fuels and chemical production. Many of the technologies for commercializing this application, from basic concepts to pilot plant, need substantial development and testing.

Clearly, if DOE is to accomplish its goals, facilities to test and verify technology are necessary. The specific test needs for the central receiver projects are listed in Table 4-1. They are somewhat different from those listed in Table 3-1 for distributed concentrating collectors, emphasizing research and development testing instead of standardization. 
Table 4-1. TEST NEEDS FOR CENTRAL RECEIVER SYSTEMS

Test and document performance of systems, subsystems, and components in order to develop and verify technologies.

Identify problems and areas for improvement in which the industrial sector could participate and which would speed commercialization of technologies.

Accumulate data on the reliability, lifetime, and life-cycle costs of systems and subsystems. This may involve accelerated degradation techniques.

Stimulate solar utilization by providing a working facility with which industry can identify, and which they can inspect, in order to aid in planning and decision making for their potential instullulions.

Be available for developing appropriate test procedures for subsystems and systems. However, except for heliostat production, it is felt that many installations will be designed to match specific applications, and no single standardized test procedure would be applicable.

As a result of the limited number and large size of the proposed central receiver installations, only one or two expensive test facilities can be justified. The cost of such facilities is substantially greater than the industrial sector can or will support. It is also clear that becuuse of the high cost of such facilities, considerable testing of components, system operation, and lifetimes will continue to take place at the large experimental and prototype installations. For some time, successive generations of central receiver systems will be modified and improved because of changes dictated by previous user experience, in a manner similar to the historical development of fossil-fueled plants.

\subsection{PRESENTLY AVAILABLE FACIITTES}

Several facilities now in operation either have been designed for testing central receiver systems, subsystems, or components or could be used for such tests. They are the 5-MW Central Receiver Test Facility (CRTF) at Sandia Laboratories in Albuquerque, N.Mex.; the 1-MW Centre National de la Recherche Scientifique(CNRS) solar furnace at Odiello, France; the 400-kW Advanced Components Test Facility (ACTF) at Georgia Institute of Technology in Atlanta, Ga.; and five smaller furnaces in the 25-45 kW range in the United States, Japan, France and North Africa. In addition, there is a $400-\mathrm{kW}$ facility utilizing a 25-m diameter surplus radar antenna in the design stage at the White Sands Missile Range. Several radiant heat flux facilities built for aerospace programs could also be used for testing receiver components. They are described in detail in Appendix C. The details of the CNRS furnace and the White Sands 35-kW furnace are also included in Appendix C. Specifications of the facilities are given in the table of Appendix B and supplement the description given here.

5-MWt Central Receiver Test Facility (CRTF), located at Sandia Laboratories in A lbuquerque, $\mathrm{N} . \overline{M e x}$, is the largest facility presently available for testing central receiver components and subsystems. It is suitable for testing scale models of receivers for the larger demonstration pilot plants, for commercial installations, and for advanced gas or liquid-metal cooled receivers. It is also testing succeeding generations of 
heliostats and instrumentation systems for use with future solar thermal plants. During many of the tests, the facility will be used to train engineers and technical personnel to operate future commercial plants.

The CRTF energy collection field presently has 222 heliastats that may be located in either a northern field or in an annular distribution around the tower. Under ideal conditions they can deliver approximately $2.4 \mathrm{MW} / \mathrm{m}^{2}$ target irradiance and temperatures over $2,000^{\circ} \mathrm{C}$. Each heliostat has an area of approximately $40 \mathrm{~m}^{2}$ and is controlled individually by a master computer system. This allows considerable flexibility in controlling target irradiance and heliostat stowage.

The CRTF receiver tower rises $61 \mathrm{~m}$ above ground and is approximately $15 \mathrm{~m}$ in diameter. Experiments can be located in test bays at the $36.6 \mathrm{~m}, 42.7 \mathrm{~m}$, and $48.8 \mathrm{~m}$ levels or on top of the tower. Elevators and hoists can lift up to five tons up the outside of the tower, or 100 tons can be raised by a lifting module inside the tower. Utility chases up the sides of the tower contain feed water pipes, high pressure steam lines, compressed gas lines, and electrical power lines for servicing the thermal and electrical power loads of the imagined experiments. A heat rejection system capable of dissipating the energy collected by receiver experiments is located on the ground at the base of the tower. A nominal 1-MW thermal working receiver containing 81 heat flux gauges is part of the CRTF and is available for diagnostic and experimental work. In addition, a realtime aperture scanning flux system is available for generating highly accurate flux maps during receiver testing.

The CRTF uses a multicomputer, distributed control system to control the heliostats, heat rejection, water treatment, and other functions. The computers used to record and analyze data, control the heliostat field, transmit data from the test bay, and collect data at the meteorological stations are all connected in a master network. An integral part of this computer-based master control system is an extensive data acquisition capability. This allows flexibility of operation and will handle over 500 channels of thermocouples and strain gauges. Also available is the Helios computer program that models the optical performance of the CRTF. Verifying this model with data from CRTF experiments has enabled performance of central receiver systems to be predicted more accurately at a variety of geographical locations.

Potential users of this facility should obtain a copy of the user's manual [27] (SAND-771173) from the Solar Thermal Test Facility Users' Association, Suite 1204, First National Bank Building, East Albuquerque, N. Mex. 87108. The manual contains detailed descriptions of the facility components and gives administrative and procedural guidelines for experiments.

As of October 1978, the CRTF was fully operable. The first test on an experimental receiver has been completed.

400-kW Advanced Components Test Facility. This is a tracking heliostat/central collector design patterned after Prof essor Giovanni Francia's solar steam generating facility located near Genoa, Italy. Operated by Georgia Institute of Technology's Engineering Experiment Station for DOE, the facility is located on the campus of Georgia Institute of Technology in downtown Atlanta, Ga. It is a relatively flexible test facility with the primary purpose of encouraging research and development in high temperature solar technology. It is well-suited for testing central receiver components such as boilers or air and liquid heaters, high temperature materials or chemical reaction systems, and high flux photovoltaic conversion systems and will be useful in educating test engineers in the operation of small central receiver systems. 
The heliostat field consists of a large number (550) of 1.1-m diameter mirrors, each focused to give an image of the sun at the receiver and driven in unison by mechanical linkages to a master electric clockwork drive mechanism. The mirror field is in the shape of an octagon approximately $38 \mathrm{~m}$ across and centered below the receiver. The focal zone is $21.3 \mathrm{~m}$ above the mirror plane and has a rim angle of approximately $45^{\circ}$. The original articulated tower supporting the receiver has been replaced by a stronger and more versatile rigid test stand with a $4 \mathrm{~m}$ by $4 \mathrm{~m}$ work platform that can support a 9.1-ton test object. Major test components are lifted into place by a mobile crane, while access to the top of the platform is provided by a permanent work hoist. The utilities available at. the work platform include a $5-\mathrm{cm}$ water line with gravity drain, 110 VAC100 amp single-phase and $208 \mathrm{VAC}-150 \mathrm{amp}$ three-phase electrical service, $620 \mathrm{kPa}$ compressed air service, and a flexible conduit system for user instrumentation wiring.

A computerized data acquisition system is available at the facility to record, reduce, and display data. The system has two 16,000-word minicomputers with peripherals and a multiplex analog to digital converter. One of the computers is located on the work platform of the test tower as an interface to the 120-channel multiplexer system expandable to 1,024 channels, which transmits data to the second computer located in the control building on the ground and serves as master controller for the system. A programmable gain amplifier enables each input channel to service a wide range of sensitivities and transducers. Signal conditioning equipment presently available at the facility includes (1) a thermocouple cold junction reference with as many as 52 channels of any type of thermocouple; and (2) 40 channels of strain gauge bridge completion circuitry. Standard flow rate, pressure, and fluid level transducers can be accommodated without additional signal conditioning. A scanning flux calorimeter is also available to measure flux levels and integrated power at the entrance aperture of a receiver or other test object. A heat rejection and feed water circulation system that includes condenser, feed water pump, desuperheater, vacuum pump, and valves is located on the ground at the edge of the heliostat field. A $550-\mathrm{kW}$ water-to-air cooling tower is also available at the site.

A potential user should obtain a copy of the Users' Manual/Management Plan [28] which also includes sections on test scheduling and facility policies and procedures. The manual should be available from either Georgia Institute of Technology or the Sonar Test Tower. Facility (STTF) Users' Association.

35-kW White Sands Solar Furnace. The White Sands furnace was originally built in 1958 at Natick, Mass., for the Quartermaster Research and Engineering Center. It was relocated to the White Sands Missile Range in New Mexico in 1973. It is similar to the larger Odiello furnace in design, except that it utilizes only one $137-\mathrm{m}^{2}$ heliostat and a fixed spherical concentrator with a focal length of approximately $11 \mathrm{~m}$. The rays are focused into a test chamber that is approximately $2.5 \mathrm{~m}$ by $2.5 \mathrm{~m}$ in cross section normal to the optical axis and $5 \mathrm{~m}$ in length. The image size is approximately $12 \mathrm{~cm}$ in diameter with a peak irradiance of some $400-\mathrm{W} / \mathrm{cm}^{2}$ near the center. The facility has a beam attenuator for varying sample irradiance and a water-cooled fast shutter for shaping exposure pulses. An ongoing effort is being made to upgrade the facility by refurbishing mirror facets and adding more instrumentation and an instrument trailer below the test chamber.

Although this furnace is of limited utility for testing central receiver components and subsystems because of the small solar image, it is useful for testing materials that might be incorporated into them and for studying solar chemical processes that show economic potential. In addition to Appendix $\mathrm{C}$, a source of information for potential users is the 
STTF Users' Association and the Experimenter's Guide for the White Sands Solar Facility [29].

350-kW White Sands Solar Furnace. Presently in the planning stage is the conversion of a surplus 25-m diameter radar antenna located on the White Sands Missile Range into a tracking point-focus solar furnace [30]. A Cassegrain optical system will be used to produce an image approximately $30 \mathrm{~cm}$ in diameter near the vertex of the dish. Under consideration is the possibility of using a compound parabolic concentrator as a reconcentrator element to provide more uniform irradiance over the exposure area. The test chamber at the vertex of the dish is approximately $20 \mathrm{~m}$ above ground level. Water, electric, and high pressure air lines will be provided to the test area. A water-cooled stop and fast shutter are also planned. A minicomputer control and data logging system with some 40 input channels will support the installation. The project is being supported by several government agencies including the Department of Defense and the Department of Energy and is expected to be in operation during early 1981.

Several solar furnaces located outside of the United States are potentially usable for solar thermal conversion research. Seven of them are discussed briefly here and are included in the table of Appendix B.

1-MW CNRS Solar Furnace. This solar furnace is located in the Pyrenees Mountains at Odiello-Font Romeu, France. It was established by the CNRS, began operation in 1970, and has seen considerable use in high temperature material studies and metallurgy of refractory metals and compounds [31]. It was also used recently to test a 1-MW cavitytype thermal receiver for the U.S. Department of Energy under a subcontract to Georgia Institute of Technology [23, p. 253-4]. It has a field of 63 heliostats, each $45 \mathrm{~m}^{2}$, that are installed on a sloping southern exposure. The heliostats are controlled by a servoed tracking system to reflect energy from the sun horizontally into a large 2,000-m paraboloid with an $18-\mathrm{m}$ focal length. The rays converge to a focus that is about $20 \mathrm{~cm}$ in diameter and has a peak irradiance of $1.6 \mathrm{~kW} / \mathrm{cm}^{2}$. Further data on this facility are given in Appendix C. However, little information was available on instrumentation and data handling capabilities at the site. Potential users of the CNRS furnace should contact the STTF Users' Association, noted previously, for details. It is expected that an experimenter's guidebook will be available in the future.

45-kW CNRS Montlouis Furnace. This was the first large solar furnace built. Constructed at Montlouis in the French Pyrenees in 1950 by Professor F. Trombe [32], it is essentially identical to the White Sands $35-\mathrm{kW}$ furnace. It has a single steerable heliostat to direct the sun's rays along an axis horizontal to a fixed parabolic concentrator. The furnace provides a peak irradiance of $1.2 \mathrm{~kW} / \mathrm{cm}^{2}$ and maximum temperature in excess of $3,000^{\circ} \mathrm{C}$. The success of this furnace led to its use as a prototype for three other single heliostat furnaces built over the next 20 years, including the one at White Sands. It also served as a model for the larger 1-MW CNRS furnace at Odiello. The furnuce is being moved to a new location outside the military complex and is expected to resume operation in late 1979.

45-kW French Army Furnace. In 1972 the French Army began operating a 45-kW thermal solar furnace at Odiello, only a few hundred metres from the 1-MW CNRS solar furnace [33]. It was designed on the same principle as the Montlouis furnace and has been used mainly by the French Army for nuclear thermal effect studies. Its significant features include the use of first-surface aluminized mirrors on the spherical concentrator and the largest single plane heliostat in use. 
35-kW Sendai Solar Furnace. The Tohoku University at Sendai, Japan, also has a solar fumace [34] constructed on the principles of the furnace at Montlouis. However, the mirrors on both the heliostat and the paraboloid concentrator are front-surface aluminized glass, and the heliostat is composed of flat mirrors in a stair-step arrangement. The aluminized first-surface mirrors are protected by a unique thin vinyl coating that apparently does not attenuate the ultraviolet portion of the solar terrestrial spectrum.

25-kW Bouzareah Tracking Paraboloid Furnace. At the same time the Montlouis furnace was being established, the Organisme National de la Recherche Scientific (ONRS) was developing a solar furnace at Bouzareah, Algeria. It consists of an electropolished aluminum paraboloidal dish with a diameter of $8.14 \mathrm{~m}$ and focal length of $3.14 \mathrm{~m}$. The power originally provided by this facility was estimated as about $25 \mathrm{~kW}$. However, over the 15 years of operation the mirror reflectivity and solar image have degraded somewhat.

Two foreign installations might be classified more correctly as experimental thermal conversion systems rather than solar furnaces. Although their primary use is in testing a particular system concept for concentrating solar energy for thermal power applications, they could also be used for testing certain types of receivers or components.

100-kW Francia Demonstration Unit. This unit, built in 1967 at St. Iario, Italy, by Professor Giovanni Francia of the University of Genoa [35], served as a model for the recently completed Georgia Institute of Technology ACTF. The facility uses 271 flat mirrors, $1 \mathrm{~m}$ in diameter, and a receiver $9 \mathrm{~m}$ above the center of the field. With a direct insolation of $0.9 \mathrm{~kW} / \mathrm{m}^{2}$, this facility proniseer $15 n \mathrm{~kg}$ of steam per hour at 150 atmospheres and $500^{\circ} \mathrm{C}$, for an overall efficiency of $70 \%$.

40-kW Mitsubishi Demonstration. The second installation that is of similar design is the tower system constructed during 1976 by Mitsubishi Heavy Industries, Ltd., at the Hiroshima Technical Institute, Hiroshima, Japan [36]. The facility has 88 heliostats with a total mirror area of $97 \mathrm{~m}^{2}$, a $15-\mathrm{m}$ test tower, a test receiver, and thermal loop. The heliostats operate on the same principle as the kinematic motion device developed by Professor Francia. Data obtained with this receiver predict a thermal efficiency of $78 \%$, with a surface temperature of $300^{\circ} \mathrm{C}$ and an output of approximately $40 \mathrm{~kW}$ of thermal power. Based on the $40-\mathrm{kW}$ facility, Japan is designing a 1-MW electrical pilot plant using 850 heliostats (each $16 \mathrm{~m}^{2}$ ) with a steam receiver at the top of a $68-\mathrm{m}$ tower that is scheduled to begin operation in November 1980 .

There are several additional furnaces in Europe and Russia that are either in the planning stages or for which little data were available at the time of this writing. In France a $2.7-\mathrm{MW}$ e central receiver facility is planned at Targasonne, about $10 \mathrm{~km}$ west of Odeillo. It is anticipated that the facility will be finished in 1981 and will be used for testing system components. Spain is planning to have three installations near Almeria. One is a $1-\mathrm{MW}_{\mathrm{e}}$ central receiver funded by the European community and involving many of the same design team as at Targasonne. The second is a $500-\mathrm{kW}$ facility funded and planned by the IEA. It has been reported that the third facility near Almeria is being planned by the Spanish government. The Italians are planning a $1-M W_{e}$ concentrator to be built on Sicily. Finally, Russian facilities are known to exist in Crimea and near Tashkent. Again no details were available.

Solar Simulators and Radiant Heat Facilities. In closing this section, mention should be made of six radiant heat facilities and six solar simulators identified by the Aerospace 
Corporation [1] as having potential for testing components for the solar thermal program. Since the names and the details are available in that report, attached as Appendix $\mathrm{C}$, only general comments are appropriate here. These facilities are all electrically powered and, except for one solar simulator requiring $140 \mathrm{~kW}$, they require 23- to 74-MW electrical power for operation. In general, the simulators can be focused to provide effective concentration ratios from 1 to over 1000 for varying test areas. The flux levels available in the radiant heat facilities are reported to be greater than 100 $\mathrm{W} / \mathrm{cm}^{2}$ from quartz lamps and over $400 \mathrm{~W} / \mathrm{cm}^{2}$ from graphite radiant heaters in two of the installations. Test areas as large as $3 \mathrm{~m}$ by $3 \mathrm{~m}$ and as high as $5 \mathrm{~m}$, depending on the facility, can be obtained. The major drawbacks of these facilities for testing solar thermal systems components are threefold. First, their size and finite source-tocollector distance make them inappropriate for testing concentrators or heliostat optical performance. Second, the spectral content of the source does not match that of the solar spectrum, especially for the radiant heat facilities, which have large amounts of infrared power with very little power in the visible wavelengths. Finally, the large electrical power requirements make them inappropriate for steady-state tests or degradation studies, which require operation over extended periods. However, there are undoubtedly tests for which these facilities could be utilized, and thus they should be kept in mind by the solar thermal research community.

\subsection{CONCLUSIONS AND RECOMMENDATIONS FOR CENTRAL TEST FACILITIES}

The existing and planned solar furnaces and test facilities cover a wide range of designs and sizes. This diverse set of facilities appears to meet the present and planned needs of the DOE Solar Central Receiver Program. Unless the volume of testing becomes too heavy in the future and a clear need develops, the construction of any additional facilities in this class should be avoided. Since nothing short of large solar furnaces can duplicate the thermal and spectral energy needed to demonstrate the feasibility of receiver subsystems, the radiant heat facilities and solar simulators previously constructed by the aerospace industry appear to be of limited utility for this purpose.

Several solar furnaces in Europe, northern Africa, and Japan offer the possibility of international cooperation in solar thermal research and a greater opportunity for subsystem and component tests by experimenters. The Solar Thermal Test Facility Users' Association [37] provides a central contact for anyone proposing to use these large test facilities for experimental work. The association provides a necessary coordination function, which includes helping the experimenter determine which facility is appropriate for the test; providing additional literature and documentation on the facilities; and assisting in pretest administration and procedural matters. Presently the association also has a limited amount of funding available for implementing experiments. 
SझRl 


\section{SECTION 5.0}

\section{REFERENCES}

1. Aerospace Corporation. Central Receiver Solar Thermal Power System: Review and Summary of Available Test Facilities. Report No. ATR 75(7370)-2, NTIS Access No. PB 243.

2. Wahlig, M.; et al. Control System for Solar Heating and Cooling. Lawrence Berkeley Laboratory, LBL-4436, Aug. 1975.

3. Simon, F. Flat-Plate Solar Collector Performance Evaluation with a Solar Simulator as a Basis for Collector Selection and Performance Prediction. NASA Technical Memorandum, NASA TMX-71793, 1975.

4. Simon, F. and Buyco, E. in "Radiative Transfer and Thermal Control-Progress in Astronautics and Aeronautics." Vol. 49, editor Allie M. Smith. American Institute of Aeronautics and Astronautics, New York, N.Y., 1976.

5. NASA/Marshall Document SHC-2009. Dec. 1, 1975, and private communication.

6. American Society of Heating, Refrigerating and Air-Conditioning Engineers, Inc. Methods of Testing to Determine the Thermal Performance of Solar Collectors. ASHRAE Standard 93-77, New York, N.Y., 1977.

7. HUD-PDR-189-8, Mar. 1978.

8. Niessing, W. J. Laboratories Technically Qualified to Test Solar Collectors in Accordance with ASHRAE Standard 93-77: A Summary Report. NBSIR 78-1535 National Bureau of Standards, Nov. 1978.

9. The MITRE Corporation. Systems Descriptions and Engineering Costs for Solar Related Technologies, Vol. III. Report No. MTS-7485, June 1977.

10. InterTechnology Corporation. Analysis of the Economic Potential of Solar Thermal Energy to Provide Industrial Process Heat. Report No. COO/2829-76-1, Feb. 1977.

11. Solar Energy Research and Development: Program Balance: Vol. 1,2. HCP/M2693-01 and -02. Prepared for U.S. DOE by Stanford Research Institute, Feb. 1978.

12. Treadwell, G. W. and Grandjean, Norman. "Annual Performance Comparisons of Parabolic Trough and Flat Plate Collectors Based on Measured Insolation." Proceedings of Concentrating Solar Collector Conference/Workshop. Georgia Institute of Technology, Atlanta, Ga., Sept. 26-28, 1977.

13. Collares-Pereira, M. and Rabl, A. Simple Procedure for Predicting Long Term Average Performance of Nonconcentrating and of Concentrating Solar Collectors. Argonne National Laboratories, Report ANL 78-67. 
14. U.S. Department of Energy, Division of Solar Technology, Washington, D.C. 20545. Solar Thermal Power Systems: Program Summary. DOE/ET-0018/1, January 1978.

15. DOE/ERDA, RFP EG-77-R-04-0022; PRDA EG-77-D-29-002.

16. Solar Age 3, Feb. 1978. p. 12.

17. Reed, Kent. Argonne National Laboratories, Argonne, Ill., personal communication.

18. French, Bob. American Technological University, Fort Hood, Tex., personal communication.

19. Desert Sunshine Exposure Tests, Inc., Box 185, Black Canyon Stage, Phoenix, Ariz. 85020. Specification DSET 75-SE2, 2nd Revision, Jan. 10, 1978.

20. Jet Propulsion Laboratory, Pasadena, Calif. Point Focusing Distributed Receiver Technology Project Management Report No. 12, Jpl 5104-27, Aug. 1978 and personal communication with Darrell L. Ross.

21. Solar Thermal Energy Test Facilities Project-Semiannual Reports. SAND 76-0167, SAND 76-0205, SAND 76-0425, SAND 76-0662, and SAND 77-0738.

22. Castle, Jim. STAM: SERI Standard Module for Collector Evaluation. SERI/TR-34043. Aug. 1978.

23. Walton, J.D. Jr. "International Development in Concentrators." Proceedings of the Solar 'Thermal Concentrating Collector Technology Symposlum, Jun. 14 and 15, 1978. Gupta, B.P. and Kreith, F., editors. SERI/TP-34-048, Aug. 1978.

24. Perrier, J.L. "Capteur Solaire a Concentration." Revue Internationale d'Heliotechnique, 2, 1977. pp. 54-55.

25. Peters, Phillip J. "Comparative Technical Evaluation of Solar Collectors" in Proceedings of Society of Photo-Optical Instrumentation Engineers. (SPIE). Vol. 68, Optics in Solar Energy Utilization, 1975.

26. SERI, Golden, CO. Presented at DOE Thermal Power Systems Planning Seminar. Feb. 13-14, 1978.

27. Sandia Laboratories, Albuquerque, N.M. 87115, Solar Thermal Test Facility Experiment Manual SAND-77-1173.

28. Engineering Experiment Station, Solar Energy and Materials Technology Division, Georgia Institute of Technology, Atlanta, Ga. 30332. Users' Manual/Management Plan - Advanced Components Test Facility. Apr. 1978.

29. Nuclear Weapons Effect Branch, Applied Sciences Div., Army Material Test and Evaluation, White Sands Missile Range, N.M. 88002. Experimenter's Guide, White Sand Solar Facility (WSSF). 1977. 
30. Hull, W.C. "The White Sands Missile Range $400 \mathrm{~kW}$ Solar Furnance-Project Review" in Proceedings of Annual Meeting Technical Sessions, Solar Thermal Test Facilities Users' Association, 11-12 Apr. 1978, Golden, Colo.

31. Trombe, F. and Royere, C. New Mexico State University, Las Cruces, N.M. "CRNS $1000 \mathrm{~kW}$ Solar Furnance" in Proceedings NSF International Seminar on Large Scale Solar Energy Test Facilities, Nov. 18-19, 1974. pp. 137-186.

32. Trombe, F. "Les Installations de Montlouis et le Four Solaire de $1000 \mathrm{~kW}$ d'OdeilloFont-Romeu." Colloques Internationaux du Centre National de la Recherche Scientifique, No. LXXXV, Application Thermiques de l'Energie Solaire dans de Domaine de la Recherche et de I'Industrie Montlouis, June 23-28, 1958. pp. 87-128, CNRS, Paris, 1961 .

33. Meunier, R.M. "Caracteristiques et Objectifs des Fours Solaires du Laboratoire Central de l'Aemement." In Rev. Int. Htes Temper, et Refract. 1973, t. 10, pp. 297-302.

34. Sekurai, T. New Mexico State University, Las Cruces, N.Mex. "Study on the Solar Furnace Instrumentation in Tohoku University." Proceedings NSF International Seminar on Large Solar Energy Test Facilities, Nov. 18-19, 1974, pp. 67-97.

35. Francia, G. New Mexico State University, Las Cruces, N.M. University of Genoa Solar Furnace. Proceedings NSF International Seminar on Large Scale Solar Energy Test Facilities, Nov. 18-19, 1974, pp. 99-136.

36. Nakamura, N. Solar Energy Collecting Test Apparatus. In-house paper of Mitsubishi Heavy Industries, Ltd., 1976-1977.

37. Solar Thermal Test Facilities Users' Association, Suite 1507, First National Bank Bldg., East, Albuquerque, N.Mex. 87108. 


\section{SझRl絭}




\section{APPENDIX A}

A.1 DATA SHEETS FOR SURVEY OF SOLAR THERMAL TEST FACILITIES DISTRIBUTED CONCENTRATING COLLECTORS 


\section{FACLITY SURVEY DATA SHEET: Distributed Systems}

Name: Solar Engineering Test Module

Location: American Technological University, Kileen, Texas

$\underline{\text { PURPOSE }}$

Testing concentrating collectors in support of the ATU/Fort Hood Solar Total Energy Military Large-Scale Experiment (LSE No. 1)

\section{CAPABILITIES AND DESCRIPTION}

A. Collectors

1. Types - Varies; concentrators

2. Numbers and Size - Varies; concentrators

3. Total Area $-40 \mathrm{~m}^{2}$ aperture maximum

4. Mounting Structures - None; pad available

B. Heat Management

1. Temperature Range - $280^{\circ} \mathrm{C}$

2. Pressure Range - $7.2 \mathrm{MPa}$

3. Working Fluids - Water

4. Flow Rates $-0.1-0.51 / \mathrm{s}$

5. Load Applications - None

6. Supplementary Sources - Resistance preheater at collector inlet

C. Storage - None presently; may be added at a later date

D. Data Acquisition and Management

1. Computer - Acurex Autodata Nine

2. Data Channels (analog/digital) - 40 (digitized)

3. Sample Rate - Capabilities up to $10 \mathrm{sec} /$ data set

4. Transducers - Thermocouples and RTD's, Turbine flowmeters

5. Accuracy - Temperature $\pm 0.3^{\circ} \mathrm{C}$, Flow $\pm 0.1 \%$

6. Meteorological - NIP, $30^{\circ}$ clear pyranometer, windspeed and direction

7. Storage - Printed tape

8. On-Line Fluid Analysis - No

E. System Control

1. Type - Manual or auto (Acurex Unit)

2. Operator Qualification - Not known

3. Human Engineering - Manual or auto control

USES

Presently not being used and is no longer applicable to the revised Fort Hood System Design.

NOTES

Contact: Bob French, (817) 526-1168 


\section{FACILITY SURVEY DATA SHEET: Distributed Systems}

Name: Argonne Solar Energy Test Facility

Location: Argonne National Laboratories, Argonne, IL

PURPOSE

Characterize performance of stationary or seasonally adjusted nonimaging concentrating collector modules

\section{CAPABILITIES AND DESCRIPTION}

A. Collectors

1. Types - Various nonfocusing concentrators

2. Total Area - $20 \mathrm{~m}^{2}$ each loop

3. Mounting Structures -2 aluminum alt-azimuth mounts, $\mathbf{3}$ adjustable steel frames, and 4 aluminum frames fixed at latitude

B. Heat Management (Three portable and one fixed loops)

1. Temperature Range: Ambient $-260^{\circ} \mathrm{C}$

2. Pressure Range: $\sim 800 \mathrm{kPa}$;

3. Working Fluids: Water, ethylene glycol, T66

4. Flow Rates: $-0.1 \mathrm{l} / \mathrm{s}$

5. Load Applications - discharge to heat exchanger

6. Supplem entary Sources - Emersion heater to control inlet temperatures

C. Storage - None

D. Data Acquisition and Management

1. Computer - Data General Nova with Camac interface and Doric 100 pt. data logger

2. Data Channels (analog/digital) - 50 channels each Camac module

3. Sample Rate - Up to $20 / \mathrm{s}$

4. Transducers - Thermocouples: 5 in temperature mode, 1 in reference mode

5. Accuracy $\sim 0.1^{\circ} \mathrm{C}$

6. Meteorological - Standard met. station at Argonne plus Epply PSP, NIP, and 8-48; California Meas. active cavity radiometer, and wind speed

7. Storage - Magnetic tape and diskettes

8. On-Line Fluid Analysis - No

E. System Control

1. Type - Monitor inlet temperature and manually throttle flow rates

2. Operator Qualification - Technician

3. Human Engineering - Not applicable

USES

A. Present Use - Sporadic since October 1977

B. Projected or Proposed - Continue tests of nonfocusing concentrators

C. Availability - Available to other labs on a cooperative basis provided they supply resources and manpower

NOTE

Contact Kent Reed, (312) 972-6234 


\section{FACILTY SURVEY DATA SHEET: Distributed Systems}

Name: Low Technology Collector Test Facility

Location: Brookhaven National Laboratories, Upton, New York

PURPOSE

Identify and test very low cost, low temperature collectors for assisting heat pumps

\section{CAPABILITIES AND DESCRIPTION}

A. Collectors

1. Types - Generally flat-plate

2. Numbers and size $-6-10$ units, $10 \mathrm{~m}^{2}$ each

3. Total Area - $100 \mathrm{~m}^{2}$ maximum but can test only 1 unit at any one time

B. Heat Management

1. Temperature Range - Low temperature $10^{\circ}-20^{\circ} \mathrm{C}$

2. Pressure Range - Near ambient

3. Working Fluids - Air

4. Flow Rates $-2.5 \mathrm{~m} / \mathrm{s}, 1 \mathrm{~m}^{3} / \mathrm{s}$

5. Load Applications - Eventually will have heat pump

6. Supplementary Sources - None

C. Storage - None presently

D. Data Acquisition and Management

- . 1. Computer - None

2. Data Channels (analog/digital) - By hand with supporting chart recorders

3. Sample Rate - Continuous record on chart readouts

4. Transducers - Temperature thermopile; Flowrate, Pitot tubes

5. Accuracy $-2 \%$

6. Meteorological - Use Brookhaven's station

7. Storage - None

8. On-Line Fluid Analysis - None

E. System Control

1. Type - Manual

2. Operator Qualification - Unknown

3. Human Engineering - Many individual controls

USES

A. Present Use - One trial panel has been run

B. Projected or Proposed - Continued testing of low temperature collectors

C. Availability

1. For facility-run experiments - Perhaps available for other government program experiments

2. For experimenter-run experiments - Probably none

3. For operator training - Not appropriate

NOTES

Contact: Gary Cottingham, Brookhaven, FTS 666-4610 


\section{FACIITY SURVEY DATA SHEET: Distributed Systems}

Name: DSET Laboratories, Inc.

Location: Box 1850, Black Canyon Stage, Phoenix, AZ

\section{PURPOSE}

Performance durability and reliability testing of materials and solar collectors.

\section{CAPABILITIES AND DESCRIPTION}

A. Collectors

1. All types of flat-plate and most concentrating designs

2. Numbers -6 water loops, 2 air loops, 2 alternate fluid loops

3. Total Area - 20 to $30 \mathrm{~m}^{2}$

4. Mounting Structures - alt-azimuth, fixed angle also available

B. Heat Management

1. Temperature Range (Inlet) - Water $-180^{\circ} \mathrm{C}$; Air $-10-\mathrm{cm}$ pipe at $105^{\circ} \mathrm{C}$, and $20-\mathrm{cm}$ pipe at $205^{\circ} \mathrm{C}$; alternate fluid $-230^{\circ} \mathrm{C}$

2. Pressure Range - I MPa for air and water, $400 \mathrm{kPa}$ for alternate fluids

3. Working Fluids - Water, air, various heat transfer fluids

4. Flow Rates - Water - to $40 \mathrm{l} / \mathrm{min}$; Alternate Fluid - to $80 \mathrm{l} / \mathrm{min}$; Air $4 \mathrm{~m}^{3} / \mathrm{min}$ at $10-\mathrm{cm}$ duct and $34 \mathrm{~m}^{3} / \mathrm{min}$ with $20-\mathrm{cm}$ duct

5. Load Applications - Heat exchanger using evaporative cooler

6. Supplementary Sources - Heater to control inlet temperature

C. Storage - Thermal storage on request

D. Data Acquisition and Management

1. Computer - Data General Nova 3D with plotter

2. Data Channels (analog/digital) - 4 Esterline Angus Data Loggers (A/D included)

3. Sample Rate - Maximum all channels each $15 \mathrm{sec}$

4. Transducers - Thermocouples, flowmeters, RTDs

5. Accuracy - ASHRAE standards

6. Meteorological - 10 Eppley Precision Pyranometers; 3 Normal Incident and 1 Absolute Cavity Pyrheliometers; 2 Eppley UV and 1 Spectral Radiometers

7. Storage - Hand copy report, Floppy disk

E. System Control

1. Open and closed loops with manual controls operated by technician

2. Tracking controls use balanced cell output technique

USES

A. Present Use Factor - $100 \%$ of clear days for component evaluation, long-term operational testing, and $R \& D$

B. Projected or Proposed-Continue commercial testing of collectors and expanded use for integrated systems testing and test method development

C. Available for collector testing as schedules permit

NOTES

Contact: M. W. Rupp, (602) 465-7356 


\section{FACILITY SURVEY DATA SHEET: Distributed Systems}

Name: Molten Salt Test Loop

Location: General Atomic Co., San Diego, CA

\section{PURPOSE}

Test molten salts as heat transfer fluid in high temperature solar collector

\section{CAPABILITIES AND DESCRIPTION}

A. Collectors

1. Types - General Atomic's Fixed Mirror Solgr Concentrator (FMSC)

2. Numbers and size -6 FMSC modules $-9 \mathrm{~m}^{2}$ each

3. Total Area $-51 \mathrm{~m}^{2}$

B. Heat Management

1. Temperature Range - Up to $600^{\circ} \mathrm{C}$

2. Pressure Range - Max $160 \mathrm{kPa}$

3. Working Fluids $-680 \mathrm{~kg}$ of $\mathrm{Hitec}^{\mathrm{TM}}$ salt

4. Flow Rates $-1 \mathrm{l} / \mathrm{s}$

5. Load Applications - None - dissipated to atmosphere

6. Supplementary Sources - Tank has $48 \mathrm{~kW}$ heater, fluid lines have trace heaters with $15 \mathrm{~kW}$ total capacity to prevent salt freeze up

C. Storage - Single tank without thermocline; has $\mathrm{N}_{2}$ blanket

D. Data Acquisition and Management

1. Computer - None

2. Data Channels (analog); Digital readouts - Multichannel strip chart recorders can be added

3. Sample Rate - Continuous

4. Transducers - Thermocouples and resistance thermometers; orifice flow meter

5. Accuracy - Uncertain

6. Meteorological - Pyranometer, Pyrheliometer

7. Storage - Chart paper

8. On-Line Fluid Analysis - None; could extract samples out of tank

E. System Control

1. Type-Automatic tracking, flow rate controlled by temperature set on output

2. Operator Qualification-Research installation requiring technical background and training on system

\section{USES}

A. Present Use: Full-time project support

B. Projected Use: After July 1979 available for other experiments on time and material basis 


\section{FACILITY SURVEY DATA SHEET: Distributed Systems}

Name: Point Focusing Solar Thermal Test Site

Location: JPL Edwards Test Station, Edwards Air Force Base, California

PURPOSE

System and subsystem test and evaluation of industry developed point focusing solar concentrators, thermal receivers, and power converters as part of a planned program for solar energy research and development

\section{CAPABILITIES AND DESCRIPTION}

A. Collectors

1. Types - Point focus, sun tracking

2. Numbers and size - 6-m diameter: 1 dish; $11-m$ diameter: 2 dishes under construction, 6 dishes planned

3. Total Area - $1100 \mathrm{~m}^{2}$

4. Mounting Structures - Footing on concrete pads

B. Heat Management

1. Temperature Range - $315^{\circ} \mathrm{C}$

2. Pressure Range $-8.6 \mathrm{MPa}$ (steam); $0.31 \mathrm{MPa}$ (air)

3. Working Fluids - Steam or air

4. Flow Rates $-0.5-2 \mathrm{~kg} / \mathrm{hr} / \mathrm{kW}_{\text {th }}$ (steam); $2 \mathrm{~g} / \mathrm{s} / \mathrm{kW}_{\text {th }}$ (air)

5. Load Applications - Water cooled thermal; resistive electrical

6. Supplementary Sources - TBD

C. Storage - TBD

D. Data Acquisition and Management

1. Computer - PDP-11/10, PDP-1134A, LSI-11 with RT-11 and RSX-11M operating systems

2. Data Channels (analog/digital) -600 (3 Autodata-Nine loggers and miscellaneous input/output circuits)

3. Sample Rate - $10 \mathrm{sec} /$ digital channel (16 bits); $40 \mathrm{msec} /$ analog-channel

4. Transducers - Tr., RTD, flow, etc.

5. Accuracy - $1 \%-5 \%$

6. Meteorological - Insolation, temperature, wind and direction, humidity, barometric pressure

7. Storage - Magnetic tape

8. On-Line Fluid Analysis - TBD

E. System Control

1. Type - Automated with manual override

2. Operator Qualification - In-house training

USES

A. Present Use - Testing started in FY79

B. Projected or Proposed - Short-term experiments and long-term trend analyses

C. Available for facility-run point-focusing; high temperature systems experiments, and operator training

NOTES

Contact: Marrell L. Ross (213) 354-4321 


\section{FACILTY SURVEY DATA SHEET: Distributed Systems}

Name: Experimental Solar Controls Test Facility Location: Lawrence Berkeley Labs, Berkeley, CA

\section{PURPOSE}

(1) Develop computer control strategies and programs (ROMS) for heating/cooling systems; (2) Test absorption cooling unit based on low temperature $\mathrm{NH}_{3}$ cycle

\section{CAPABILITIES AND DESCRIPTION}

A. Collectors

1. 'I'ypes - HLât-platé

2. Numbers and size -20 units - PPG

3. Total Area $-30 \mathrm{~m}^{2}$

4. Mounting Structures - Mounted on Roof at $45^{\circ}$

B. Heat Management

1. Temperature Range $-90^{\circ} \mathrm{C}$ limit

2. Pressure Range $-200 \mathrm{kPa}$

3. Working Fluids - Water with Nelco corrosion suppressant

4. Flow Rates - Heating loop $1 \mathrm{l} / \mathrm{s}$, load loop $1.5 \mathrm{l} / \mathrm{s}$

5. Load Applications - Heat exchanger liquid to air and simulator

6. Supplem entary Sources - Gas boiler

C. Storage $-1.2 \mathrm{kl}$

D. Data Acquisition and Management

1. Computer - HP 9825 A

2. Data Channels (analog/digital)-Doric Data Logger 99 channel with printer - Inter faced to HP9825A

3. Sample Rate - 1 sec/data point

4. Transducers - T.C. and solid sensors (NS LX-5700)

5. Accuracy - Heat balance to $6 \%$

6. Meteorological - DOE Load and Weather Tape

7. Storage - Print out, Tape, Cartridge or Floppy Disk

8. On-Line Fluid Analysis - None; occasionally extract fluid for tests

E. System Control

1. Type - PROM on/off actuators

2. Operator Qualification - Unknown

USES

A. Present Use - $100 \%$ for in-house programs

B. Projected or Proposed - Continued use for above programs

C. Availability

1. For experimenter-run experiments - Collector testing, heat exchangers, etc.; could be run by other labs together with LBL technicians

2. For operator training - Not suitable

NOTES

Contact: Mashwi Warren, FTS 45 1-6364, Mike Wahlig, 451-5787 


\section{FACIITY SURVEY DATA SHEET: Distributed Systems}

Name: Systems Engineering Building

Location: NASA/Langley, Hampton, VA

PURPOSE

Used as a collector test bed. Also used to heat and cool office building using flat-plate collectors - driving an absorption chiller

\section{CAPABILITIES AND DESCRIPTION}

A. Collectors

1. Types - Flat-Plate and tracking

2. Numbers and size -13 rows $100 \mathrm{~m}^{2}$ each, 6 different manufacturers and several different models

3. Total Area - $1300 \mathrm{~m}^{2}$

4. Mounting Structures - Remote from building

B. Heat Management

1. Temperature Range $-\angle 100^{\circ} \mathrm{C}$, used to drive a $180 \mathrm{~T}$. LiBr chiller

2. Pressure Range $-275 \mathrm{kPa}$ in collectors

3. Working Fluids - Water - treated with chromates

4. Flow Rates - Variable - Max $1 \mathrm{k}: 1 / \mathrm{min}$

5. Load Applications $-5,000 \mathrm{~m}^{2}$ office building

6. Supplementary Sources - Fossil fuel back up

C. Storage - $114 \mathrm{kl}$, highly stratified and insulated

D. Data Acquisition and Management

1. Computer - Xerox computer

2. Data Channels (analog/digital) - 150 data channels

3. Sample Rate - 150 points each sec.

4. Transducers - Thermisters pressure, flow, etc. - PRT for temperature, turbine, and ultrasonic for flow.

5. Accuracy $-\left( \pm 0.5^{\circ} \mathrm{C}, \pm 2 \%\right.$ for flow on major items)

6. Meteorological - Horizontal and tilted pyranometers

7. Storage - Data stored on computer tape at 5 min intervals

8. On-Line Fluid Analysis-Tested monthly as routine maintenance procenture

E. System Control

1. Type - Thermostats and time clock, runs automatically

2. . Operator Qualification - Run by duty of ficer

3. Human Engineering - Apparently good

USES

A. Present Use $-100 \%$ used for heating and cooling building,

B. Projected or Proposed-(1) Replacement of $100 \mathrm{~m}^{2}$ of Martin-Mariętta collector with evacuated tubes is under construction; (2) Have added $100 \mathrm{~m}^{2}$ of concentrator collectors

C. Availability

1. For facility-run experiments - Operates as utility and long-term test bed

2. For experimenter-run experiments - Limited capability

3. For operator training - Not available

NOTES

Contact: Mr. Baxter Carr, FTS 928-4501, NASA/Langley (804) 827-4501 


\section{FACIITY SURVEY DATA SHEET: Distributed Systems}

Name: Lewis - Solar Simulator

Location: NASA/Marshall

PURPOSE

Do research on the performance of flat plate collectors under various conditions of illumination

\section{CAPABILITIES AND DESCRIPTION}

A. Collectors

1. Types - Flat-plate

2. Numbers and size - 1

3. Total Area $-1.22 \mathrm{~m}$ by $1.22 \mathrm{~m}$ maximum

4. Mounting Structures - Rotatable for cos dependence

B. Heat Management

1. Temperature Range $-20-100^{\circ} \mathrm{C}$ inlet temperature

2. Pressure Range - $100 \mathrm{kPa}$

3. Working Fluids - Water and ethylene - glycol

4. Flow Rates $-4 \mathrm{l} / \mathrm{min}$; wind $3 \mathrm{~m} / \mathrm{s}$

5. Load Applications - dump to heat exchanger

6. Supplementary Sources - Radiation source: 143 tungsten-halogen lamps GE Type ELH at $300 \mathrm{~W}$ each

C. Storage - None

D. Information on Data Acquisition and Management, System Control, and Uses were not available or were not applicable.

\section{NOTES}

"Radiative Transfer and Thermal Control, Progress in Astronautics and Aeronautics," Vol. 49, editor - Smith 1976, Am erican Inst. of Aeronautics and Astronautics, New York.

A. This facility has recentily been moved from Lewis Research Center to the Marshall Space Flight Center and is being used by the University of Alabama.

B. Marshall Space Flight Center also has a larger simulator with a $2.25 \mathrm{~m}$ by $4.5 \mathrm{~m}$ test area. It has $405 \mathrm{GE} \mathrm{ENH}$ tungsten-halogon lamps each operated at up to 250 watts. Fresnel lenses in front of the lamps give a collimated beam of up to $-1 \mathrm{~kW} / \mathrm{m}^{2}$ irradiance. Array can be rotated between 0 and $72^{\circ}$ from the vertical. Liquid and flow control loops operate up to $100^{\circ} \mathrm{C}$.

Contact: William A. Brooksbank, Jr., FTS 872-1248 


\section{FACILTY SURVEY DATA SHEET: Distributed Systems}

Name: Marshall Space Flight Center

Location: Huntsville, Alabama, on Redstone Arsenal

\section{PURPOSE}

Evaluation of solar energy heating and cooling systems, subsystems, and selected components: solar collectors, thermal energy storage equipment, and solar heating and cooling devices

\section{CAPABILITIES AND DESCRIPTION}

A. Collectors

1. Types - Various flat-plates cycled in and out

2. Numbers and size - Variable

3. Total Area $-400 \mathrm{~m}^{2}$ active; $150 \mathrm{~m}^{2}$ passive

4. Mounting Structures - Flat plate racks $45^{\circ}$ tilt angle

B. Heat Management

1. Temperature Range-Air: $15-125^{\circ} \mathrm{C}$; Liquid: $15-125^{\circ} \mathrm{C}$; Water: 15$300^{\circ} \mathrm{C}$ HT fluids

2. Pressure Range - To $1 \mathrm{MPa}$

3. Working Fluids - Air, Water, HT fluids

4. Flow Rates - Air: $0.25-2.5 \mathrm{~m}^{3} / \mathrm{s}$; Liquid: $1-101 / \mathrm{s}$

5. Load Applications - Heating, cooling

6. Supplementary Sources - Simulate collect output $130 \mathrm{~kW}$; cooling load to 10 tonnes; heating load $35 \mathrm{~kW}$

C. Storage - Rock: 20 tonnes; Liquid: $40 \mathrm{kl}$

D. Data Acquisition and Management

1. Computer - Old. Being replaced by new Data Acquisition system at each test set

2. Data Channels (analog/digital) - 950 Analog up to computer

3. Sample Rate - Once every min

4. Transducers - Temperature: PRT; Pressure: strain gauges; Liquid Flow: turbines; Heaters: watt meters

5. Accuracy - ASHRAE 93-77 specification

6. Meteorological - Pyroheliometer, pyranometer, wind, temperature, etc.

7. Storage - Computer files

8. On-Line Fluid Analysis - No

E. System Control

1. Type - Manual set

2. Operator Qualification - Special training required

3. Human Engineering - Poor

USES

A. Present Use $-<25 \%$, depending on DOE request

B. Projected or Proposed - Plan to test collector and components in support of DOE/ERDA Demonstration Program

C. Availability

1. For facility-run experiments - $100 \%$

2. For experimenter-run experiments - None

3. For operator training - None

NOTES: Operated by Wyle Labs for NASA; Sources: NASA-Marshall Document SHC2009, December 1, 1975 and on-site inspection. 


\section{FACILITY SURVEY DATA SHEET: , Distributed Systems}

Name: NBS

Location: Gaithersburg, Maryland

PURPOSE

Develop standardization and testing methods, e.g., ASHRAE 93-77 for collectors (Flat plate)

\section{CAPABILITIES AND DESCRIPTION}

A. Collectors

1. Types - Flat-plates

2. Numbers and size -2 loops for single $\left(3 \mathrm{~m}^{2}\right.$ each) flat plates; 3 loops for 4 collcet aide by side with individual flow, through each eollertnr $\left(10 \mathrm{~m}^{2}\right)$; 1 loop air collect $\left(6 \mathrm{~m}^{2}\right)$

B. Heat Management

1. Temperature Range - Water to $100^{\circ} \mathrm{C}$; Air, $70-80^{\circ} \mathrm{C}$ exit temperature

2. Pressure Range - Near ambient

3. Working Fluids - Water, air

4. Flow Rates $-60 \mathrm{ml} / \mathrm{s}$ single loop; $240 \mathrm{ml} / \mathrm{s} 4$ collector loop; up to 0.5 $\mathrm{m}^{3} / \mathrm{s}$

5. Load Applications - None, dump heat

6. Supplementary Sources - Resistance heater to control inlet temperature

C. Storage - One $2.5 \times 2.5 \times 2.5 \mathrm{~m}^{3}$ pebble bed for an air loop

D. Data Acquisition and Management

1. Computer - None

2. Data Channels (analog/digital) - Data logger - tape drive 100 channels. Digital output

3. Sample Rate - Normally 2 minute interval

4. Transducers - T.C., Homemade Thermopiles, PRT's

5. Accuracy $-0.15^{\circ} \mathrm{C}$ on temperature; $1 \%$, liquid flow; $2-3 \%$, air flow using ASME nozzle

6. Meteorological - Pyroheliometer, pyranometer, sky temperature radiom eter (custom-made by French Building Research Inst.)

7. Storage - Tape

8. On-Line Fluid Analysis - None

E. System Control

1. Type-Leeds-Northup thermostat controllers on inlet feeds; manual control of flow rates

2. Operator Qualification - Technician

3. Human Engineering - Not applicable

\section{USES}

A. Present Use $->90 \%$

B. Projected or Proposed - Continue research on test methods

C. Availability

1. For facility-run experiments - Not in business of running other people's tests

2. For experimenter-run experiments - None

3. For operator training - None

Source: Dr. J. Hill, FTS 921-3559 


\section{FACILITY SURVEY DATA SHEET: Distributed Systems}

Name: Collector Module Test Facility (Part of Midtemperature Solar System Test Facility)

Location: Sandia Labs, Albuquerque, New Mexico

PURPOSE

Characterize and report collector module performance and support advanced collector research

CAPABILITIES AND DESCRIPTION

A. Collectors

1. Typcs - Line focus and distributed

2. Numbers and size-One collector module of up to $45 \mathrm{~m}^{2}$ on each of 3 loops

3. Mounting Structures - 2 loops on fixed footings, 1 loop on turntable base

B. Heat Management

1. Temperature Range $-\max 330^{\circ} \mathrm{C}$ for water and $425^{\circ} \mathrm{C}$ for oils

2. Pressure Range $-1 \max 18 \mathrm{MPa}$ with water and $1.4 \mathrm{MPa}$ with oil

3. Working Fluids - Therminol 66; Syltherm 800; and water

4. Flow Rates - up to $11 / \mathrm{s}$

5. Load Applications - Heat exchanger to water

6. Supplementary Sources - resistance heaters to heat transfer fluids to required test temperatures

C. Storage - None

D. Data Acquisition and Management

1. Computer - HP 1000 system

2. Data Channels (analog/digital) - typically 120 channels of ther mocouple and low-level signals for each loop

3. Sample Rate - depends on number of channels used-4 $\mathrm{min}$ at slowest rate

4. Transducers - Type T, J, and E. Thermocouples, flow meters, and pressure gauges

5. Accuracy - Ther mocouples $+1 \%$, Flow meters $\pm 5 \%$

6. Meteorological - NIP, a mbient temperature, wind direction/velocity

7. Storage - IVlagnetic tape and/or disk plus hard-copy printer and plotter

8. On-Line Fluid Analysis - None

E. System Control

1. Type-Thermostatically controlled fluid inlet temperature; electropneumatic control on flow rate; computer, microprocessor, or manual control

2. Operator Qualification - technician training in electronics and mechanics

3. Human Engineering-safe operating procedures and quality program plans required for operation

USES

A. Present Use-Equipment supports simultaneous operation of two loops to characterize new concepts and advanced design collectors

B. Projected-RFP for 4-month procurement of prototype collector; new concepts development RFP

C. Availability - $100 \%$ utilized for facility-run experiments for DOE.

NOTES

Contact: Bob Workhoven, FTS 475-5427 


\section{FACLITY SURVEY DATA SHEET: Distributed Systems}

Name: System Test Facility (part of Midtemperature Solar System Test Facility) Location: Sandia Labs, Albuquerque, New Mexico

\section{PURPOSE}

Determine and demonstrate the technical and economic feasibility of solar total energy systems for a variety of sites and loads

\section{CAPABILITIES AND DESCRIPTION}

A. Collectors

1. 'i'ÿpes - Line focus and distributed point focus concentr'ulu's

2. Numbers and size -5 subsystems each with $\max 500 \mathrm{MJ} / \mathrm{hr}\left(-200 \mathrm{~m}^{2}\right)$

3. Total Area $-\sim 1000 \mathrm{~m}^{2}$

4. Mounting Structures - Individual footings

B. Heat Management

1. Temperature Range - up to $315^{\circ} \mathrm{C}$ in primary distribution loop

2. Pressure Range - up to $0.6 \mathrm{MPa}$

3. Working Fluids - Therminol 66 in primary loop

4. Flow Rates - up to $3 \mathrm{l} / \mathrm{s}$

5. Load Applications $-32 \mathrm{~kW}$ turbine/generator with toluene working fluid; (100 tonne) absorption cycle chiller; space heat and hot water for 1,100 $\mathrm{m}^{2}$ building; cooling tower, $360 \mathrm{~W}$

6. Supplem entary Sources - 2 fossil fuel heaters $0.3 \mathrm{MW}$ each

C. Storage $-3.7 \mathrm{~m}^{3}$ high temperature $\left(425^{\circ} \mathrm{C}\right)$ stratified Therminol tank; three 24 $\mathrm{m}^{3}$ tanks capable of storing $880 \mathrm{kWh}$ thermal between $243^{\circ} \mathrm{C}$ and $310^{\circ} \mathrm{C}$

D. Data Acquisition and Management

1. Computer - HP2l MXE

2. Data Channels - 600 total available. At each of $\overline{7}$ bulkheads there are typically 40 channels for Type $T$ and 12 channels for Type $J$ thermocouples, and 20 channels for other low-level signals

3. Sample Rate - function of number of channcls in use - slowest rate $=4$ $\min$

4. Transducers - Type T, J, and $\mathrm{K}$ thermocouples, flow meters, and pressure gauges

5. Accuracy - Thermocouples, $+1 \%$; Flow meters $+5 \%$

6. Meteorological - Wind direction and velocity, ambient air and dew point temperatures, and direct and horizontal solar radiation

7. Storage - Magnetic tape, disk, hard-copy printer and plotter

8. On-Line Fluid Analysis - None

E. System Control

1. Type-Honeywell temperature controllers (handset) on valves for fluid flow to maintain constant outlet temperature. Inlet temperature from bottom of thermocline. May be by computer, microprocessor, or manual.

2. Operator Qualification-Technologist with electronics and mechanical background. Two operators needed for control, safety, etc.

3. Human Engineering - Computer system may not be appropriate for all field applications. Two operators needed for control, safety, etc. Safe operating procedures and quality program plan required. 
USES
A. Present Use $-90 \%$

B. Projected or Proposed - Continued testing of subsystems on rotational basis.

Sources: SAND 76-0167, SAND 76-0205, SAND 76-0662, SAND 77-0738

Contact: T. D. Harr ison, FTS 475-6394 or (505) 264-6394 


\section{FACILITY SURVEY DATA SHEET: Distributed Systems}

Name: Solar Experimental Research and Applications for Process Heat (SERAPH)

Location: Solar Energy Research Institute, Golden, CO

PURPOSE

An experimental system for solar energy research and application

CAPABILITIES AND DESCRIPTION (Design Parameters)

A. Collectors

1. Types - Varies; concentrator

2. Numbers and size - Variable

3. Total Area - up to $500 \mathrm{~m}^{2}$

4. Mounting Structures - One-Axis Tracking, Stationary

B. Heat Management

1. Temperature Range $-400^{\circ} \mathrm{C}$

2. Pressure Range $-3.5 \mathrm{MPa}$

3. Working Fluids - Pressurized $\mathrm{H}_{2} \mathrm{O}$, Heat Transfer Fluids

4. Flow Rates -1 to $6 \mathrm{l} / \mathrm{s}$

5. Load Applications - Cooling and Heating Load Simulator

6. Supplem entary Sources - Oil-fired heat exchanger (1 GJ/hr)

C. Storage - Varies

D. Data Acquisition and Management - To be coupled with SERI Data Acquisition System

1. Computer - local system - LSI 11

2. Data Channels (analog/digital) - 200-500.

3. Sample Rate - unknown

4. Transducers - pressure, temperature, flow rate

5. Accuracy - unknown

6. Meteorological - unknown

7. Storage - unknown

8. On-Line Fluid Analysis - None

E. System Control

1. Type - Manual, analog, supervisory, DDC,

2. Operator Qualification - Technician

3. Human Engineering - combination graphics and annunciator

USES

A. Present Use - (not complete)

B. Projected or Proposed-Experimental system for research on process heat applications

C. Availability

1. For facility-run experiments - Primarily for study relating to Solar Process Heat Application, also large scale environmental heating and cooling

2. For experimenter-run experiments - Available

3. For operator training - For industrial solar energy system operators

NOTES

SERI Contact: Jim Castle 


\section{FACILITY SURVEY DATA SHEET: Distributed Systems}

Name: Standard Module (STAM)

Location: SERI, Golden, CO

\section{PURPOSE}

Develop thermal performance standards appropriate for concentrating collectors; investigate impact of circumsolar on concentrating collectors; provide a test bed for advance receiver and component development (and conduct both short- and long-term reliability studies).

\section{CAPABILITIES AND DESCRIPTION}

A. Collectors

1. Types - Varies; concentrators

2. Numbers and size - simultaneous capability for 2 collectors

3. Total Area - Aperture maximum $\sim 40 \mathrm{~m}^{2}$

4. Mounting Structures - I rotating asimuthal platform and 2 fixed stands

B. Heat Management

1. Temperature Range - Water $230^{\circ} \mathrm{C}$, Heat Transfer Oils $350^{\circ} \mathrm{C}$

2. Pressure Range $-3.8 \mathrm{MPa}$

3. Working Fluids - Water, Heat Transfer Oils, Therminol 66

4. Flow Rates - Varies; $0.78-37.9 \mathrm{l} / \mathrm{min}$ per collector

5. Load Applications - Dump Heat Exchanger

6. Supplementary Sources-Resistance Type Circulation Heater for Input. Temperature

C. Storage - 150 liter

D. Data Acquisition and Management

. 1. Computer - Initially - LSI-11

2. Data Channels (analog/digital) -30

3. Sample Rate - Variable; $1 / \mathrm{s}_{\text {, }}$ to $1 / \mathrm{min}$

4. Transducers - Various

5. Accuracy - Striving for overall $1-2 \%$ in overall thermal performance

6. Meteorological - On-site weather station and radiometers

7. Storage - Presently on cassette tape, proposed floppy disk

8. On-Line Fluid Analysis - None

E. System Control

1. Type-Flow rate-initially manual, adaptable for automatic; temp-proportional

2. Operator Qualification - TBD

USES

A. Present Use - Design Phase

B. Projected or Proposed - Operational by Sept. 1979

C. Availability

1. For facility-run experiments - Primarily

2. For experimenter-run experiments - Yes

3. For operator training - Probably in the future

NOTES

SERI Contact: Allan Lewandowșki 


\section{FACILITY SURVEY DATA SHEET: Distributed Systems}

Name: Collector Test Loops

Location: University of Chicago, Chicago, IL 60637

PURPOSE

Test facility for prototype nonimaging concentrating collectors

\section{CAPABILITIES AND DESCRIPTION}

A. Collectors

1. Types - CPCs and nonimaging two stage conoentratore

2. Numbers and size -2 each-1.6 m, 1 each-1.1 m $\mathrm{m}^{2}, 1$ each-1.8 $\mathrm{m}^{2}$

3. Mounting Ştructures - Two-axis (horizontal-vertical) manually positioned rack $2 \mathrm{~m}^{2}$

B. Heat Management - Two circulating loops A and B

1. Temperature Range - (A) $10^{\circ} \mathrm{C}-90^{\circ} \mathrm{C}$; (B) $10^{\circ} \mathrm{C}-300^{\circ} \mathrm{C}$

2. Pressure Range - (A) atmospheric; (B) $0-340 \mathrm{kPa}$

3. Working Fluids - (A) Water; (B) Therminol 66

4. Flow Rates - (A) $5-50 \mathrm{ml} / \mathrm{s}$; (B) $5-80 \mathrm{ml} / \mathrm{s}$

5. Load Applications - $(A \& B)$ Heat exchangers

C. Storage - None

D. Data Acquisition and Management

1. Computer - Hewlett-Packard 9825A programmable calculator, scanner and on-line plotter

2. Data Channels (analog/digital)-40 analog channels interfaced to calculator

3. Sample Rate - Full sensor scan every 2 s-Accumulates and computes average every 1-4 min.

4. Transducers - Thermocouples, 4-terminal RTDs, turbine flowmeter

5. Accuracy $- \pm 1 \%$

6. Meteorological - Radiometric only (ACR plus two Eppley 8-48s)

7. Storage - On magnetic tape cassettes

8. On-Line Fluid Analysis - (Uses calorimetric ratio technique to calibrate fluid $\mathrm{T}$ for known heat source)

E. System Control

1. Type - Manual (Flow rate, heater power, etc.)

2. Operator Qualification - Informal

USES

A. Present and Projected Use - Nearly $100 \%$ on sunny days, plus some heat loss testing yielding net of $\sim 35 \%$ of real time

B. Available only for facility-run experiments

NOTES

Contact: J. J. O'Gallagher (312) 753-8637 


\section{APPENDIX A}

A.2 RESPONSES TO QUESTIONNAIRE MAILED TO CONCENTRATING COLLECTOR MANUFACTURERS 
QUESTIONNAIRE RESPONSES FROM COLLECTOR MANCFACTURERS

\begin{tabular}{|c|c|c|c|}
\hline \multirow[b]{2}{*}{ Question } & \multirow[b]{2}{*}{ Solar Kineties, Inc. } & \multicolumn{2}{|c|}{ Respcinse } \\
\hline & & Northrup, Inc. & Acurex Cororation \\
\hline Compeny Location & $\begin{array}{l}8120 \text { Chancellor Row } \\
\text { Dallas, TX } 75247\end{array}$ & $\begin{array}{l}302 \text { Nichols Dr. } \\
\text { Hutchins, TX } i_{5141}\end{array}$ & $\begin{array}{l}485 \text { Clyde Ave. } \\
\text { Mountain View, CA } 94042\end{array}$ \\
\hline Solar Resource at Site & $\longrightarrow$ & $\begin{array}{l}\text { High insolation rates, high per- } \\
\text { centage of sunshine (See Climatic } \\
\text { Atlas) }\end{array}$ & . \\
\hline $\begin{array}{l}\text { What is the purpose of the } \\
\text { facility? }\end{array}$ & $\begin{array}{l}R \& D \text { and production of parabolic } \\
\text { trough concentrating collectors }\end{array}$ & $\begin{array}{l}\text { Development of solar collectors; } \\
\text { determine performan ze curves; } \\
\text { monitor hot water systems }\end{array}$ & $\begin{array}{l}\text { In-house development, production } \\
\text { testing, and quality control of } \\
\text { various thermal and photovoltaic } \\
\text { collectors }\end{array}$ \\
\hline $\begin{array}{l}\text { Facilities Capabilities and } \\
\text { Description }\end{array}$ & & & \\
\hline $\begin{array}{l}\text { 1. What types of collectors can } \\
\text { be tested? }\end{array}$ & Al & $\begin{array}{l}\text { Liquid flat-plate collectors } \\
\text { and concentrating collectors }\end{array}$ & $\begin{array}{l}\text { One- and two-axis tracking collec- } \\
\text { tors, thermal, and photovoltaic }\end{array}$ \\
\hline $\begin{array}{l}\text { 2. How many collectors can be } \\
\text { tested independently and at } \\
\text { the same time? }\end{array}$ & See Below & $\begin{array}{l}\text { Four collectors can be tested } \\
\text { at once, but they must all be } \\
\text { at the same inlet tersperature }\end{array}$ & $\begin{array}{l}\text { Three to four different types, } 3 \\
\text { different loops exist (1. High } \\
\text { temp, 2. Low temp, and } 3 \text {. High } \\
\text { pressure) }\end{array}$ \\
\hline $\begin{array}{l}\text { 3. What is the total collector } \\
\text { area that can be tested at } \\
\text { one time? }\end{array}$ & $50 \mathrm{~m}^{2}$ & $9 \mathrm{~m}^{2}$ & $48 \mathrm{~m}^{2}$ ther $\mathrm{mal}$ collectors \\
\hline $\begin{array}{l}\text { 4. On what type of structure } \\
\text { are the collectors mounted? }\end{array}$ & Steel Pylons & $\begin{array}{l}\text { Flat-plate tracker, concentra- } \\
\text { tor tracker, a fixed nount }\end{array}$ & Concrete piers \\
\hline $\begin{array}{l}\text { 5. Operating parameter limits } \\
\text { Temperature } \\
\text { Pressure } \\
\text { Fluid Flow }\end{array}$ & $\begin{array}{c}315^{\circ} \mathrm{C} \\
1.7 \mathrm{MPa} \\
0.006-1.251 / \mathrm{s}\end{array}$ & $\begin{array}{c}175^{\circ} \mathrm{C} \\
0.86 \mathrm{MPa} \\
0-0.21 / \mathrm{s}\end{array}$ & $\begin{array}{c}315^{\circ} \mathrm{C} \\
2.7 \mathrm{MPa} \text { at } 200^{\circ} \mathrm{C} \\
\end{array}$ \\
\hline $\begin{array}{l}\text { 6. What working fluids does } \\
\text { your system use? }\end{array}$ & Thermal Oils and W'ater & Water & Water and heat transfer oils \\
\hline
\end{tabular}


QUESTIONNAIRE RESPONSES FROM COLLECTOR MANUFACTURERS (continued)

\begin{tabular}{|c|c|c|c|c|}
\hline & \multirow[b]{2}{*}{ Question } & \multicolumn{3}{|c|}{ Response } \\
\hline & & Solar Kinetics, Inc. & Northrup, Inc. & Acurex Corporation \\
\hline 7. & $\begin{array}{l}\text { Is the collected energy } \\
\text { used or rejected to the } \\
\text { at masphere through a heat } \\
\text { exchanger? }\end{array}$ & Space heating and rejection & $\begin{array}{l}\text { Optional: Heat can be rejected } \\
\text { to the atmosphere or into the } \\
\text { test lab building }\end{array}$ & Rejected to atmosphere \\
\hline 8. & $\begin{array}{l}\text { Are supplementary heaters } \\
\text { used to preheat inlet } \\
\text { fluid or to provide a sim- } \\
\text { ulated source or load for } \\
\text { other components of solar } \\
\text { powered systems? }\end{array}$ & . & $\begin{array}{l}\text { An in-line heater controls the } \\
\text { fluid inlet temperature }\end{array}$ & Yes \\
\hline 9. & $\begin{array}{l}\text { What, if any, capabilities } \\
\text { exist for thermal storage? }\end{array}$ & Oil $-0.8 \mathrm{~m}^{3}$ & $\begin{array}{l}120-1 \text { and } 50-1 \text { tanks; various } \\
\text { tank sizes to } 320-1 \text { are avail- } \\
\text { able }\end{array}$ & None \\
\hline \multirow[t]{5}{*}{10.} & $\begin{array}{l}\text { How are data acquired and } \\
\text { managed? }\end{array}$ & & & \\
\hline & Computer & $\begin{array}{l}\text { Rustrak Cromemco } 64 \mathrm{~K} \text { computer } \\
\text { Chart recorders; }\end{array}$ & $\begin{array}{l}\text { 2240-A Fluke Datalogger. } \\
\text { Houston Instrument two-pen strip } \\
\text { chart recorders. Eppley pyrana- } \\
\text { meter and pyrheliometer }\end{array}$ & Autodata 9 data acquisition systems \\
\hline & Transducers (accuracy) & $\begin{array}{l}\text { Omega bimetal copper-constant } \\
\text { Rampo and flow tech. flow meters }\end{array}$ & $\begin{array}{l}\text { For pressure measurement } \\
\text { bourdon tube gages are used, } \pm \\
35-\mathrm{kPa} \text { accuracy }\end{array}$ & Thermocouples and RTDs \\
\hline & $\begin{array}{l}\text { Meteorological data- where } \\
\text { obtained? }\end{array}$ & $\begin{array}{l}\text { Epply radiom eter NIP } \\
\text { Epply radiometer } 8-48 \\
\text { Anemometer }\end{array}$ & $\begin{array}{l}\text { Ambient temperature, wind veloc- } \\
\text { ity, wind direction; TI weather } \\
\text { station }\end{array}$ & $\begin{array}{l}\text { Normal incidence and global } \\
\text { pyranometers anemometer }\end{array}$ \\
\hline & Deta Storage & Strip charts and Floppy Disks & Pluke da talogger & Paper tape printer \\
\hline
\end{tabular}


QUESTIONNAIRE RESPONSFS FROM COLLECTOR MANUFACTURERS (continued)

\begin{tabular}{|c|c|c|c|c|}
\hline \multirow{2}{*}{\multicolumn{2}{|c|}{ Question }} & \multicolumn{3}{|c|}{ Response } \\
\hline & & Solar Kinetics, Inc. & Northrup, Inc. & Acurex Corporation \\
\hline & $\begin{array}{l}\text { Are fluid temperatures } \\
\text { ther mostatically controlled? } \\
\text { Manually or electronically } \\
\text { set? }\end{array}$ & $\begin{array}{l}\text { Yes. Manual and automatic } \\
\text { pneumatic servo }\end{array}$ & $\begin{array}{l}\text { The tanks have thermostatic } \\
\text { controls that are electronical- } \\
\text { ly set. The in-line heater is } \\
\text { controlled by a variable trans- } \\
\text { iormer that is set manually }\end{array}$ & Depends on experiment \\
\hline & $\begin{array}{l}\text { Are flow rates automat- } \\
\text { ically controlled? }\end{array}$ & Yes, as above & $\begin{array}{l}\text { No. The flowmeters are check } \supseteq d \\
\text { frequently to ensure constant } \\
\text { flowrate }\end{array}$ & Yes \\
\hline & $\begin{array}{l}\text { What kind of training is } \\
\text { necessary to qualify } \\
\text { operators? }\end{array}$ & In-house & $\begin{array}{l}\text { A very general understanding of } \\
\text { heat transfer plus a few days } \\
\text { of witnessing tests. }\end{array}$ & $\begin{array}{l}\text { Engineering and/or technician } \\
\text { experience }\end{array}$ \\
\hline \multicolumn{5}{|c|}{ Facility Use } \\
\hline & $\begin{array}{l}\text { What fraction of time is it } \\
\text { presently being used? }\end{array}$ & Intermittently & $60 \%$ & $\begin{array}{l}100 \% \text { for long-term thermal and } \\
\text { photovoltaic testing }\end{array}$ \\
\hline & $\begin{array}{l}\text { What are your projected or } \\
\text { proposed uses for the } \\
\text { future? }\end{array}$ & $\begin{array}{l}\text { Continued } R \& D \text { and design } \\
\text { evaluation }\end{array}$ & $60 \%$ & \\
\hline & $\begin{array}{l}\text { Would the facility be avail- } \\
\text { able for tests run by out- } \\
\text { side experimenters? If so, } \\
\text { what restrictions or qual- } \\
\text { ifications? }\end{array}$ & No & $\begin{array}{l}\text { Yes. It must be during a time } \\
\text { of nonuse by Northrup and at } \\
\text { a fee comparable to that of an } \\
\text { independent solar test lab. } \\
\text { Test schedules could be worked } \\
\text { out in advance. }\end{array}$ & Yes, if available and contracted \\
\hline
\end{tabular}


APPENDIX B

DATA ON CENTRAL RECEIVER TEST FACILITIES 
CHARACTERISTICS OF LAHGE SOLAR FURNACES

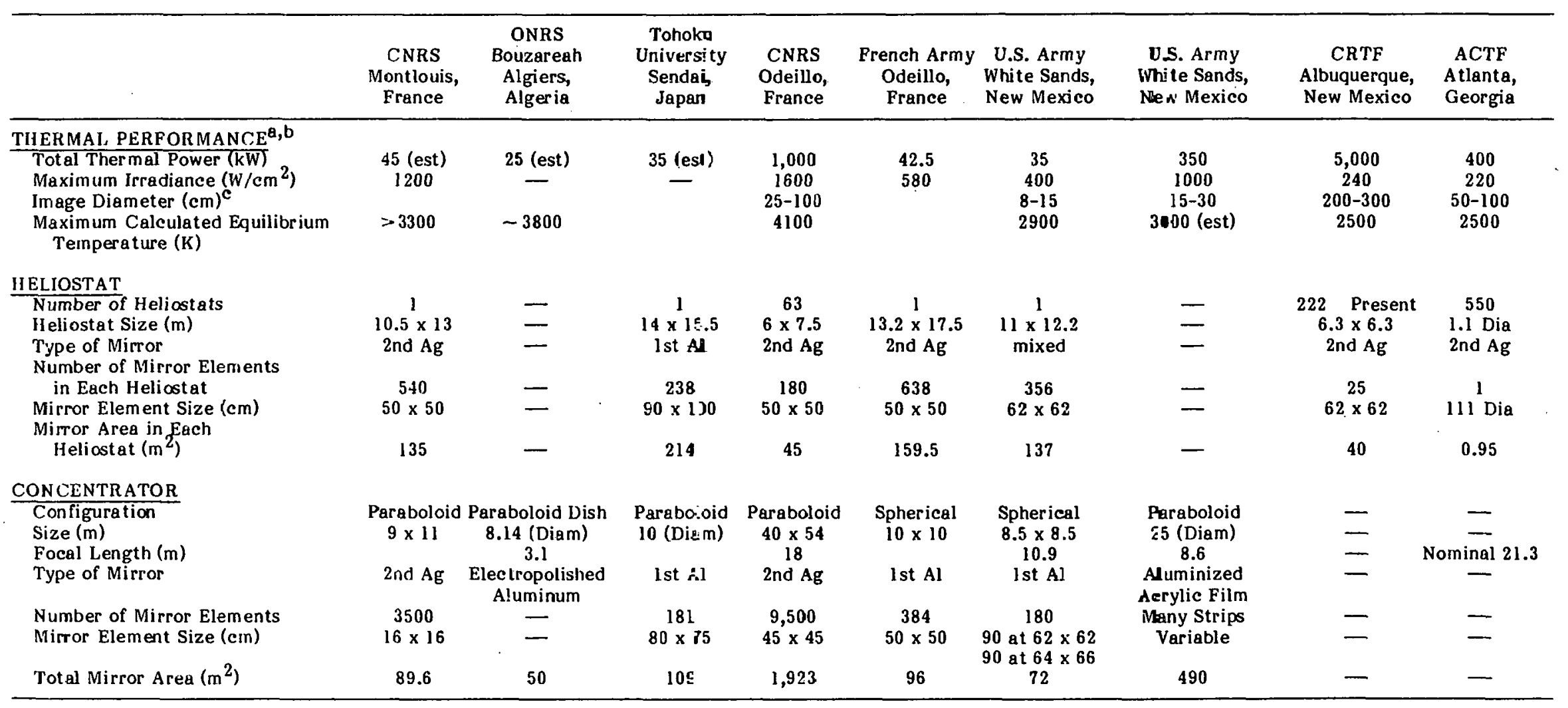


CHARACTERISTICS OF LARGE SOLAR FURNACES (Continued)

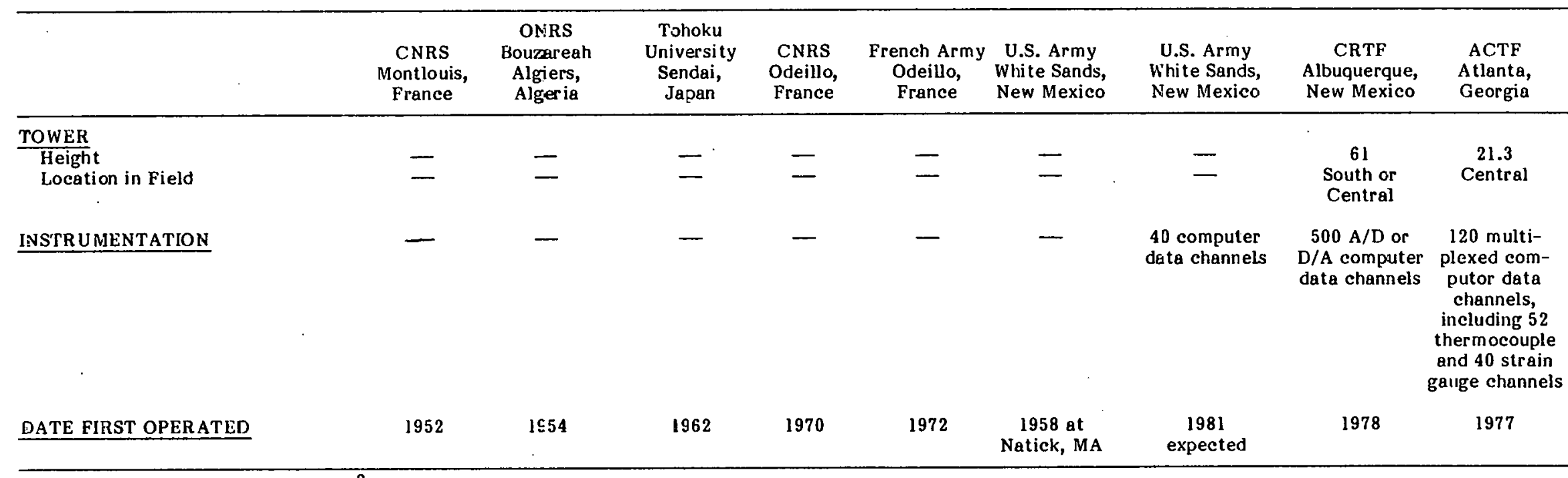

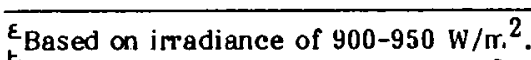

t. Heat handling capabilities at each facility are sufficient to dissipate the total thermal power from the receiver.

First number is diameter of the area receiving approximetely $1 / 2$ of total energy; the second number is the diameter of the area capturing $95 \%$ of total energy.

First number is diameter of the area receiving approximetely $1 / 2$ of total energy; the second number is the diameter of the area capturing $95 \%$ of total energy,
During 1980 the CRTF is expected to have a water-cooled aluminum compound parabolic secondary concentrator. It is designed to provide about $1000 \mathrm{~W} / \mathrm{cm} 2$ over a $23-$ $\mathrm{cm}$ diameter area. 


\section{S=Ply}

B-4 
APPENDIX C

CENTRAL RECEIVER SOLAR THERMAL POWER SYSTEM: REVIEW AND SUMMARY OF AVAILABLE TEST FACILITIES

Aerospace Corporation ATR-75-(7370)-2 


\section{CENTRAL RECENEF SOLAR THERMAL POWER SYSTEM}

\section{Review and Summary of Available Test Facilines}

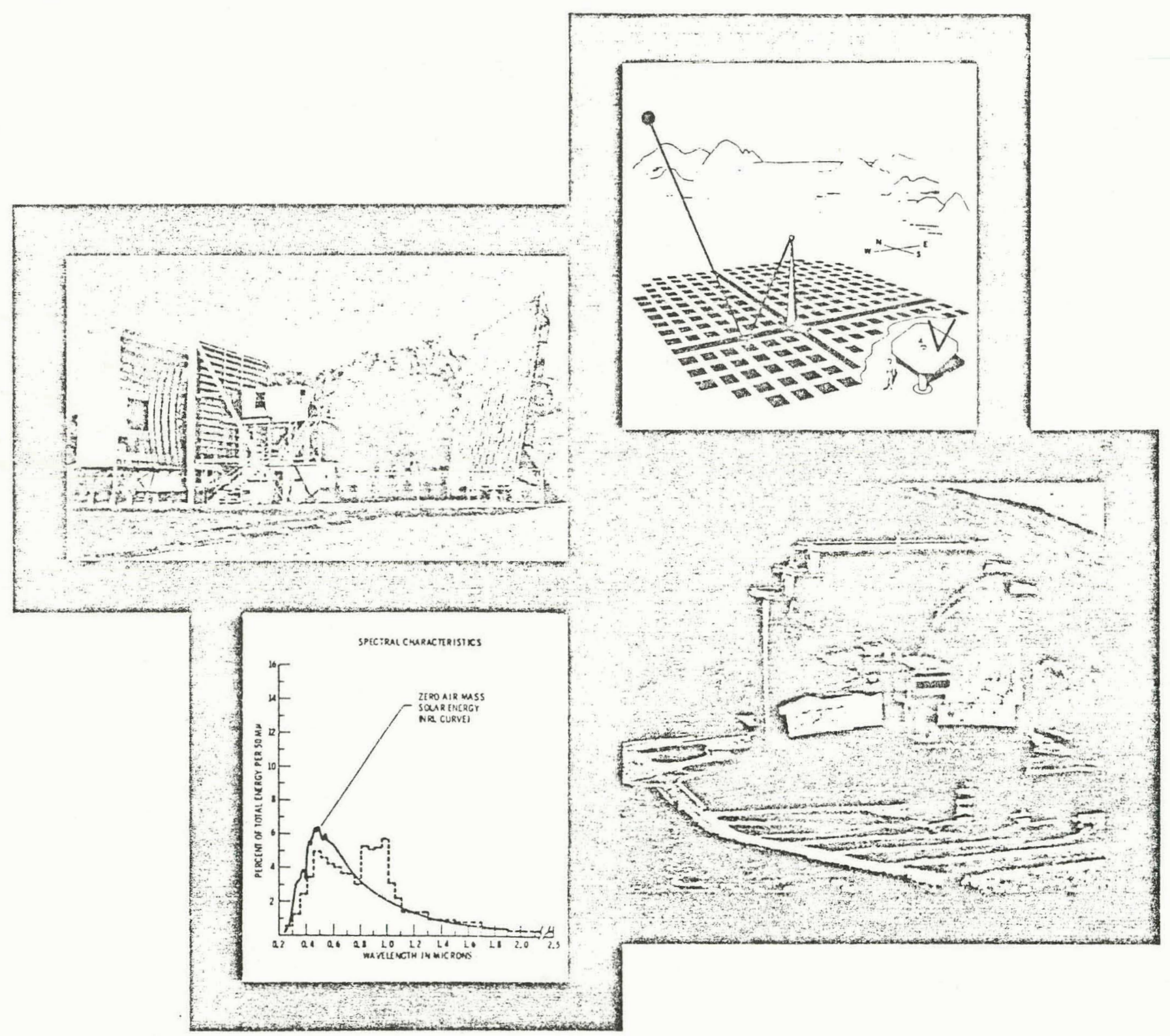


CENTEAL FECEIVES SOLAR THERMAL FOWER SYSTEM

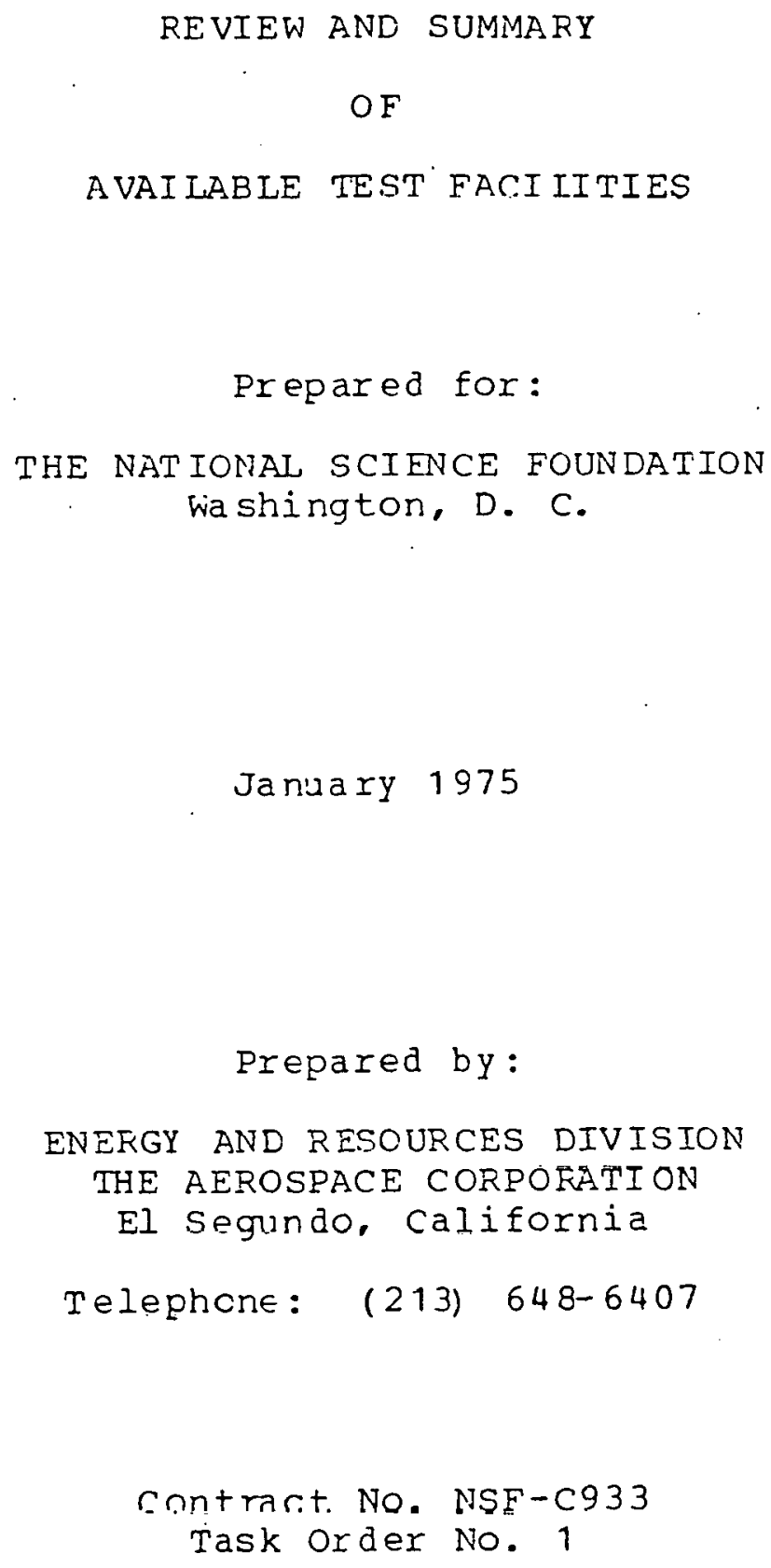


צ

THIS PAGE

WAS INTENTIONALLY

LEFT BLANK 
The Naticnal Science Foundation is undertaking th. development of a central feceiver solar Thermal power system for the conversion of solar radiation into thermal energy and than to electrical power by conventional methods. The next phase of this program will involve the efforts of several contractors or contractor teams, each preparing a preliminary design for a 10 MWe Proof-of-concept Experiment (FOCE) Pilot Plant. The preliminary designs will evolve largely from a series of subsystem research tests which are intended to verify, by actual hardware operation and evaluation, the design concepts and arlyses. The data and results of those engineering and development tests are essential to provide the proper basis for. and confidence in, the preliminary designs of the POCE Pilot plant. The PGCE Pilot Plant Preliminary Design will be technically and logically related to the proper design and construction of anticipated commercial central Receiver solar Thermal power systems. The research experiment hardware and testing procedures must simulate the system operational conditions in order to properly verify the performance expectations derived from the analyses, as well as the conceptual and developmental design efforts. of the three subsystems included in the subsystem Fesearch Experiments (collector, Receiver, and Thermal storage) the Receivor subsystem seems to pose the greatest problems concerning availability of adeguatf test facilities for conducting meaningful tests. The emphasis in this report will be concerning those facilities for the receiver subsystem experiments. Even though concerted efforts have been made to identify those facilities, both government and industrial, which could be of use in conducting such tests, no claim can be made that the coverage is complete and that all existing facilities have been included. It is believed that the more important government facilities and the better known or a vailable industrial facilities have been included. It is also believed that they are representative of existing facilities and will provide a reasonable check list for initial screenina by Frospective program participants.

The test facility descriptions were provided by personnel at each of the various test facilities. Some editing was made to the facility descriptions in the compilation of this report. The National Science Foundation and The Aerospace Corporation wish to thank each of the contributors for the effort required for the preparation of this document. These individuals are identified in the appropriate sections of the text. 


\section{1 트트르르브토}

The

objectives

of

the

Feceiver

Subsystem Research Experiments are to provide the research and test data necessary to demorstrate and verify the technical and economical feasibility of achieving solutions for the high risk technological issues of the keceiver subsystem. Since thr identification of a receiver design is the major objective of these tests, it is not possible to identify srecific configurations beyond that of the se basic concepts: (1) enclosed tube, or cavity receiver, and (2) exposed tube receiver. Either receiver concept employs thermal cycles such as indicated in Figures 1, 2, and 3. Whatever facilities are employed in the testing of the specific receiver configurations, the essential design data and verification results must be determined. Each receiver configuration will require specific and unique test procedures, instrumentation and facilities to satisfy the test objectives.

The test hardware, as a model or module of the prototype concept, must provide adequate similitude of the operational conditions in each of the areas of concern: size, flows, dynamic response, etc. , while the test facilities must provide controlled and reproducible inputs to the test hardware.

The primary requirements for the test facility are to provide steam generator interfaces which will normally exist in the central receiver system and to provide necessary data taking and reduction facilities to make the test results meaningful. The principal interfaces are the radiant heat source and fluid interfaces. In many instances, these interfares will be dictated by the particular design of the steam generator. conseguontly. test facilities must have sufficient flexibility to accommodate various steam generator desiqns as well as dynamic modes to simulate the transients of plant operations. The radiant heat source requirements will be dictated by the trade-offs between the receiver and the particular design of the collector assembly. since neither the collector nor the receiver (steam ganerator) have been designed, test facility requirements are discussed below in general terms.

The following discussions are not intended to be tutorial in nature, but are presented to indicate the general facility requirements for conducting engineering and develofment tests for the receiver concepts. The specific values are illustrative only and are not intended to specify design values.

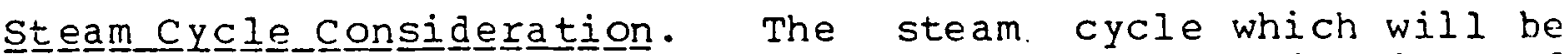
used in the central receiver will probably be some derivative of the fankine cycle. Although the exact nature of the cycle is still unknown and the temperature and pressure values a matter of speculation, scme general comments can be made. Figure 1 shows the basic Rankine steam power plant cycle. The major components $a r \in$ the steam generator, the steam turbine, the condenser, and the fluid pump. The cycle is shown on a temperature-entropy 
diagram.

In this particular

cycle, compressed liquid is introduced to the steam generator at state point 1 ( $p$ approx. 1250 psia, $T$ approx. 110 F) and exits the generator at state: point 4 (p apprcx. $1250^{\circ}$ psia, $\mathrm{T}$ approx. $950 \mathrm{~F}$ ). The test facility must be able tc crovide water to tho generator at state pcint 2 and accept it back at state point 4. There are several options for providing water at the necessary conditions: (1) water at state point 6 can be pumped to state foint 1 where it is introduced to the generator; sucerheated steam at 4 can then be dumped into the atmosphere or into a cooling pond (the primary concern in this approach is providing necessary make-up water at sufficient purityl; (2) a second approach would bo to use a high pressure condenser where steam at state point 4 will be cooled along the 4-3-2-1 curve; this is basically reversing the boiler process; the advantage of this method is that the working fluid is reused, and that the fumping power will be reduced because once the system is charged only a circulation fump will be necessary.

Figure 2 shows a Rankine cycle with one reheat. The steam generator interface is more complicated because fluid from the high pressure turbine at 5 is reheated to 6 . The turbine process from 4 to 5 and from 6 to 7 are work extraction processes whero the pressure, temperature, and energy content are reduced at. nearly constant entropy. Simulation of this process is most difficult without a turbine. A throttling process followed by a cooling process can be used to get the fluid from 4 to 5 . Also, an auxiliary boiler could be used to provide steam at state point 5 .

Other features which are generally seen in a steam power plant are additional reheats and feed-water heaters. The basic rationale for using reheats and feedwater heaters are that they improve cycle efficiency. It is not expected that the test steam generators will have many reheat cycles. Feed water heating would be considered part of the steam generator.

Both cycles considered above are subcritical cycles. A third potential cycle is the supercritical cycle shown in Figure 3. The main feature with this cycle is that the pressure is in the order of 3500 psia and the inlet and outlet temperature are approximately 110 and $850 \mathrm{~F}$, respectively.

Based upon the above discussion, power cycle interfaces were developed to serve as a basis for comparison of existing facilities. These baseline cooling system requirements are outlincd in Table I. The thermal heat load for the steam generator was assumed to be $5 \mathrm{MW}$. Consequently, for steady state tcsting, the cosling system must be capable of rejecting 5 MWth. The working fluid (water) flow rate through the steam generator will be in the crder of $1.46 \mathrm{Kg} / \mathrm{sec}(23 \mathrm{gpm})$ for the cycle shown in Figure 1. Inlet fluid to the steam generator must be conditioned to approximately $43 \mathrm{C}$ and $85 \mathrm{~A}$ TMOS. The inlet fluid (1.46 $\mathrm{Kg} / \mathrm{sec}$ of $43 \mathrm{C}$ and 85 A.TMOS water) can be from a closed cycle system or an open cycle. The type of system selected will have an impact on items such as the pump components and the cooling system and the selection of a water supply. If a 

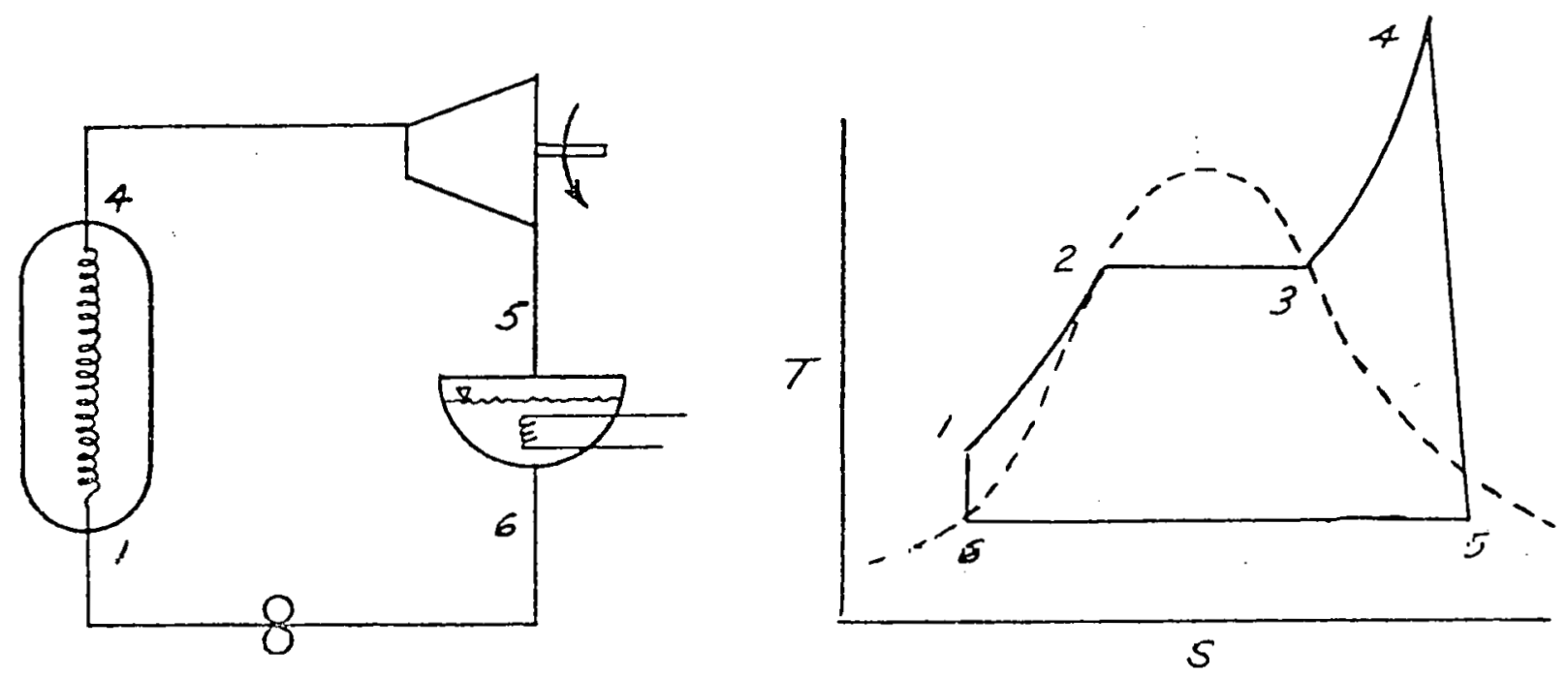

Figure 1. Simple Fankine Cycle
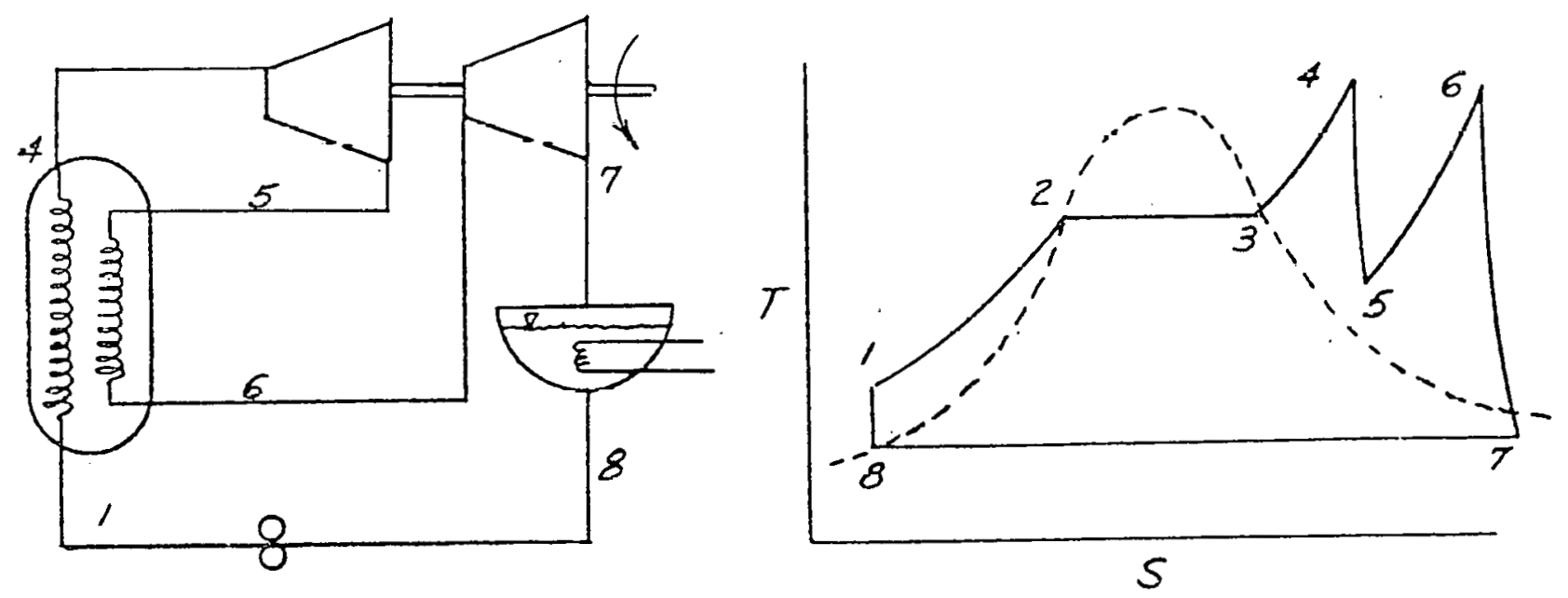

Figure 2. Rankine Cycle with Feheat 

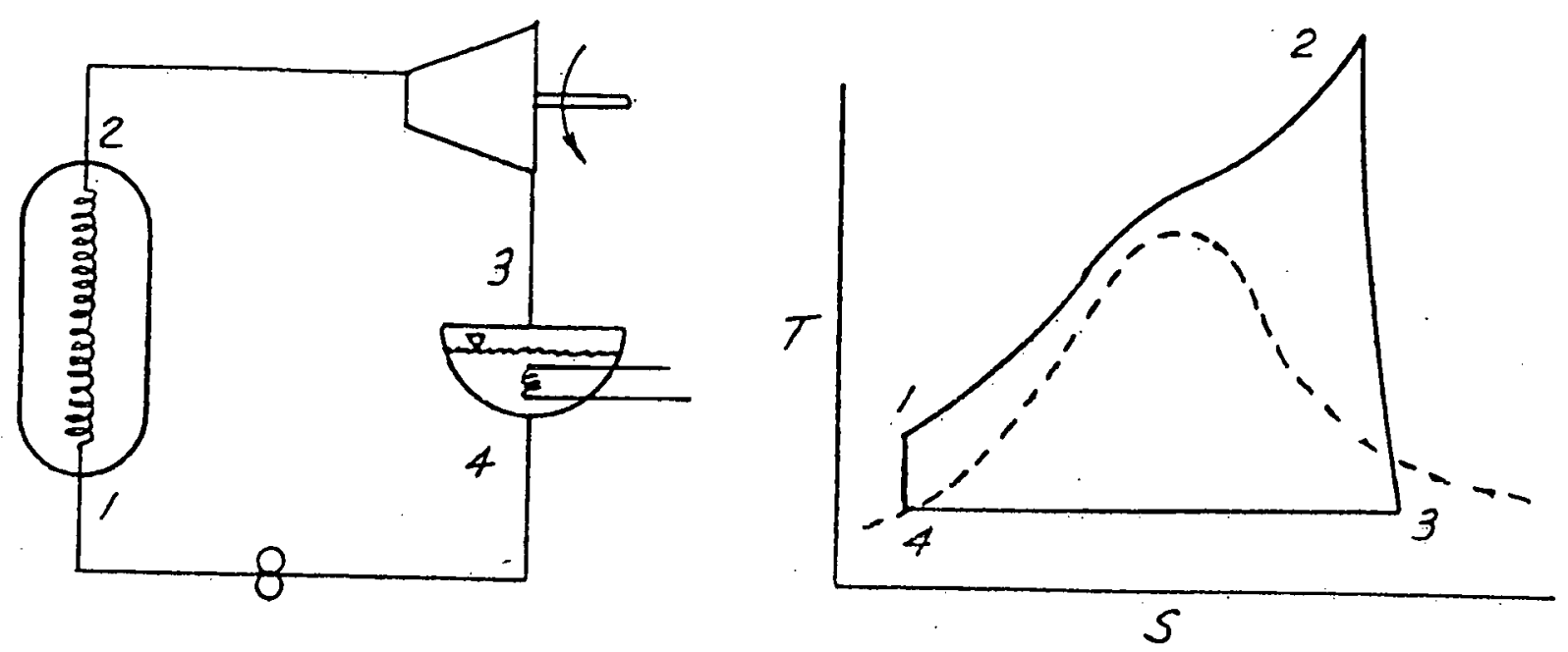

Figure 3. Supercritical Rankine Cycle

Table I. System cooling Requirements

- Heat Load

- Working Fluid Flowrate

- Fluid Inlet conditions to Generator (Primary)

$$
\text { - Temperature }
$$

- Pressure

- Fluid cutlet conditions

from Generator (Primary)

$$
\text { - Temperaturo }
$$$$
\text { - Pressure }
$$

- Fluia Inlet Conditions to Generator (Secondary)

- Temperature

- Pressure

- Fluid Inlet Conditions to Generator (Tertiary)

- Temperature

- Pressure
$5 \mathrm{MW}$

$1.46 \mathrm{~kg} / \mathrm{sec} \quad 11600 \mathrm{lb} / \mathrm{hr}$ (23 gpm)

$43 \mathrm{C}$

85 ATMOS

$110 \mathrm{~F}$

$1250^{\circ}$ psia

$510 \mathrm{C}$

85 ATMOS

$950 \mathrm{~F}$

1250 psia

$500 \mathrm{~F}$

200 psia

$5 \% \mathrm{~F}$

1250 psia 
supercritical cycle is to be tested, the pump must be able to provide water at supercritical pressure.

Superheated steam outlet conditions will be in the order of $510 \mathrm{C}$ and 85 ATMOS. If a closed cycle system is used, the system must $b \in a b l e$ to condition this fluid to the primary inlet conditions of the steam generator. This will roquire rejecting approximately $5 \mathrm{MW}$ and reduce the temperature to $43 \mathrm{C}$ whils maintaining the pressure at 85 ATMOS. If an open cycle is used, the superheated steam can be dumped (i.e... into a cooling pond).

The availability of secondary and tertiary inlet fluid is desirable. Secondary fluid conditions may be 200 psia and $500 \mathrm{~F}$ which essentially corresponds to the low pressure inlet fluid to the steam generator in the reheat cycle (Figure 2). The tertiary condition is probably the saturated steam condition (S) in Figure 1. This flexability would be useful to perform tests on the steam generator superheater.

Radiant_Energy Source. The radiant energy source (Table II) should be in the order of at least $5 \mathrm{~kW}$ thermal. The niaximum energy flux on the steam generator should be at least $1 \mathrm{Mw} / \mathrm{sg}$. meter in order to simulate the incident energy from a collector system. The system must be able to sustain enorgy/flux levels for periods sufficient to establish steady state operations. Tho irradiated area (beam) must be of sufficient size to cover the steam generator heating surfaces. It is estimated that a beam of approximately $5 \mathrm{sq}$. meters may be necessary.

There are radiant energy requirements which are yet undefined. These include a requirement to be able tc frovide a uniform incident flux across the entire test area to within $\pm T B D$. Additionally, there will be a requirement to vary the flux level from zero to the maximum level in a continuous manner. The rate of charge of the intensity will be dictated by considerations such as the simulation of cloud movement across the collector field. An additional reguirement is to be able tc control discrete secticns of the beam independently of each other. This will enable heating of various sections of the steam generator. independently of the other sections.

The heat load should be programmable. This will allow the development of heat load tapes and will obviate "turnina krobs" during the test. The system must be calibrated so that heat fluxes are known at both the test. facility/steam generator interface and directly at the tube surface.

Instrument program, one must provide as much instrumentation (Table III) as possible. The steam generator contractor must provide all instrumentation physically attached to his test article. The test facility must be able to process the data from the contractor's measuring instruments, and also measure and process data defining the test facility performance during test.

The instrumentation will consist of items such as pressure gauges, thermistors, flow meters, radiometers, and strain gauges. 
Table II. Fadiant Energy source

- Minimum Energy Level

- Maximum Intensity (at least)

- Beam Size (Afproximately)

- Beam Flux Characteristics

- Uniformity

- Variability

- Rate of Change

- Number of Discrete Uniform controllable subsections Within Beam

- Requirement for Programmed control of Individual

Subsections

- Calibration Requirement

- Flux at Generator Surface

- Flux at Generator Interface

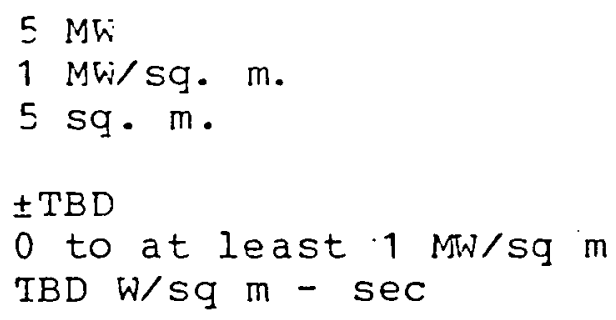

TBD

Yos

Table III. Instrumentation

- Pressure Gages

- Thermistors

- Flow Meters

compressed water

Steam

- Calorimeters

steam guality

- Fadicmeters

Heat Leak

Radiarit Energy

- Strain Gages

High Temperature

- Recorders

Digita 1

strip

Gage

Stored Tape

- Water Purity Mea surement

- Programmed Heat Load

- Process plant Type Water Flow Control system

- Constant Head Variable speed Pump

- Inlet and outlet Flow Control Based on Temperature
0 to 15000 psia

32 to $1200 \mathrm{~F}$

0 to $12000 \mathrm{lb} / \mathrm{hr}$

approximately 1000 channels 
Also test equipment such as steam quality calorimeters and water purity monitoring apfaratus will be necessary. Data should be displayed in digital read-oxts, strip charts, and gaugos; the data should alsc be stored on tafe. A measurement capability in the order of 1000 channels may be necessary.

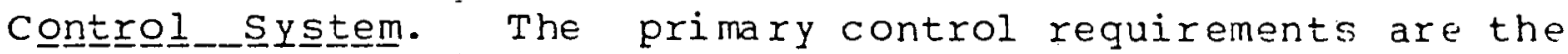
provision to pregram the heat load, and to control water flow rates to simulate various exit fluid temperature and pressure combinations which are required to simulate actual operational conditions, both steady state and transient. 
The objective of the collector subsystem Research Experiments is to assure that the collector subsystem equipments can bo produced, installed, and operated in a cost effectivr. manner. The subsystem will consist of many reflective units (heliostats), each capable of continuously directing the reflected rays of the sun to the absorptive sections of tho receiver. These units will consist of three basic components: (1) reflective surface(s), (2) supporting structure and mount, and (3) control loop and drive mechanism. The specific design features of the subsystem are intimately correlated with those of the receiver and an effective design balance between these two subsystems is required for any optimization of the central Receiver POCE Preliminary Design. Since there seem tc be no significant technological developments (except porhaps material lifetimes) required to accomplish a collector subsystem design, the testing objective, as stated above, is one of cost effectiveness for the total system design. Therefore, there seems to be little need for exotic or highly specialized oftical laboratory test facilities, or original and exhaustive procedures, beyond that necessary to establish compliance with those specifications derived from receiver/collector compatibility. Each of the possible receiver configurations will impose particular specifications on the collector configuration such as: reflected image size, flux distribution, pointing and tracking acciracies, etc. An interface of concern can be expected between the reflective surface(s) and the supforting structure which may froduce variable image distortions due to temperature, inertia, sag, wind, etc.

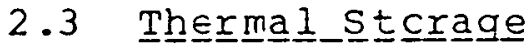

The objectives of the Thermal storage subsystem Research Experiments are similar to those for the Feceiver subsystem (Section 2.1). The Thermal storage subsystem should provide an efficient economical method to smooth out system transients and extend the power plant operation into periods of reduced insolation: The Thermal storage subsystem configuration will be directly influenced by the receiver output characteristics as well as the requirement for sustaining energy flow to the turbine generator during periods of inadequate receiver output. Whereas the energy source for the receiver tests is radiant heat, the energy source for the Thermal storage test model or module should simulate the output of the receiver (see Figures 1,2, and 3). 
The facilities which have been identified as potentially providing some useful capability for the recelver model or modula tests for the central Receiver Project may be classified in threr categories: (1) Solar Furnaces, (2) solar simulators; and (3) High Flux Radiart Heat Facilities.

(1) Solar furnaces concentrate the sun's radiant energy into relatively small test volumes and produce very high temperatures (at least 4000 degrees $K$ ) at the center of the test volume.

There are two solar furnaces which have been identified for use in the NSF test progrm, one in southern France and one at White Sands Missilé Range in New Mexico. The basic capabilities of these facilities are summarized in Table IV with more detailed information contained in sections 3.1.1 and 3.1.2. The solar Furnaces were developed and designed to produce a very high solar flux in a limited test volume. The French facility has a rated capacity of 1 Mwth and is being adapted to test early concepts of a cavity receiver. The white sands furnace has a capacity of approximately $35 \mathrm{KWth}$ and is limited to small area material and component testing.

(2) Solar simulators are designed and used to simulate the solar spectral radiation with concentrations much lower than that required for receiver module testing. There are many of theso facilities varying from modest capabilities, size, and power, to large units which provide space simulated conditions for the study of thermal responses of entire large space vehicles. Even though these larger facilities have high power cafabilities (i.e., some greater than $7 \mathrm{MW}$ ), the flux levels of incident radiation on test surfaces is significantly below that required for operational tests of receiver modules or models. Some use of these facilities may be made at these lower flux levels to verify materials for surface absorption and reflectivity. By use of optical collectors or concentrators, high flux levels can be attained over relatively small areas. In this respect, these facilities suffer the same limitation as the solar furnace at White Sands. Table $V$ summarizes some of the capabilities of a few solar simulation facilities. Additional information ma be found in sections 3.1.3 through 3.1.6.

(3) Radiant heat facilities have been developed tc produce high temperatures to simulate various environments of nuclear bursts, re-entry heating, fires, etc., and to study their effects on materials, components, and fuel assemblies. These high flux values and high temperatures are achieved with quartz lamp banks for flux levels up to approximately $100 \mathrm{Btu} / \mathrm{sq}$ ft-sec $(113 \mathrm{~W} / \mathrm{sq}$ $\mathrm{cm})$ and with graphite radiant heaters approaching $500 \mathrm{Btu} / \mathrm{sq} \mathrm{ft}-$ sec. Match of the radiated ensrgy is in the I.P. and does not simulate the solar spectrum. However, there seoms little hope, short of the POCE pilot plant or a speciai solar thermal test. facility, of matching the solar spectrum at the high energy levels required to demonstrate the feasibility of receiver 
Table IV. Solar Furnaces

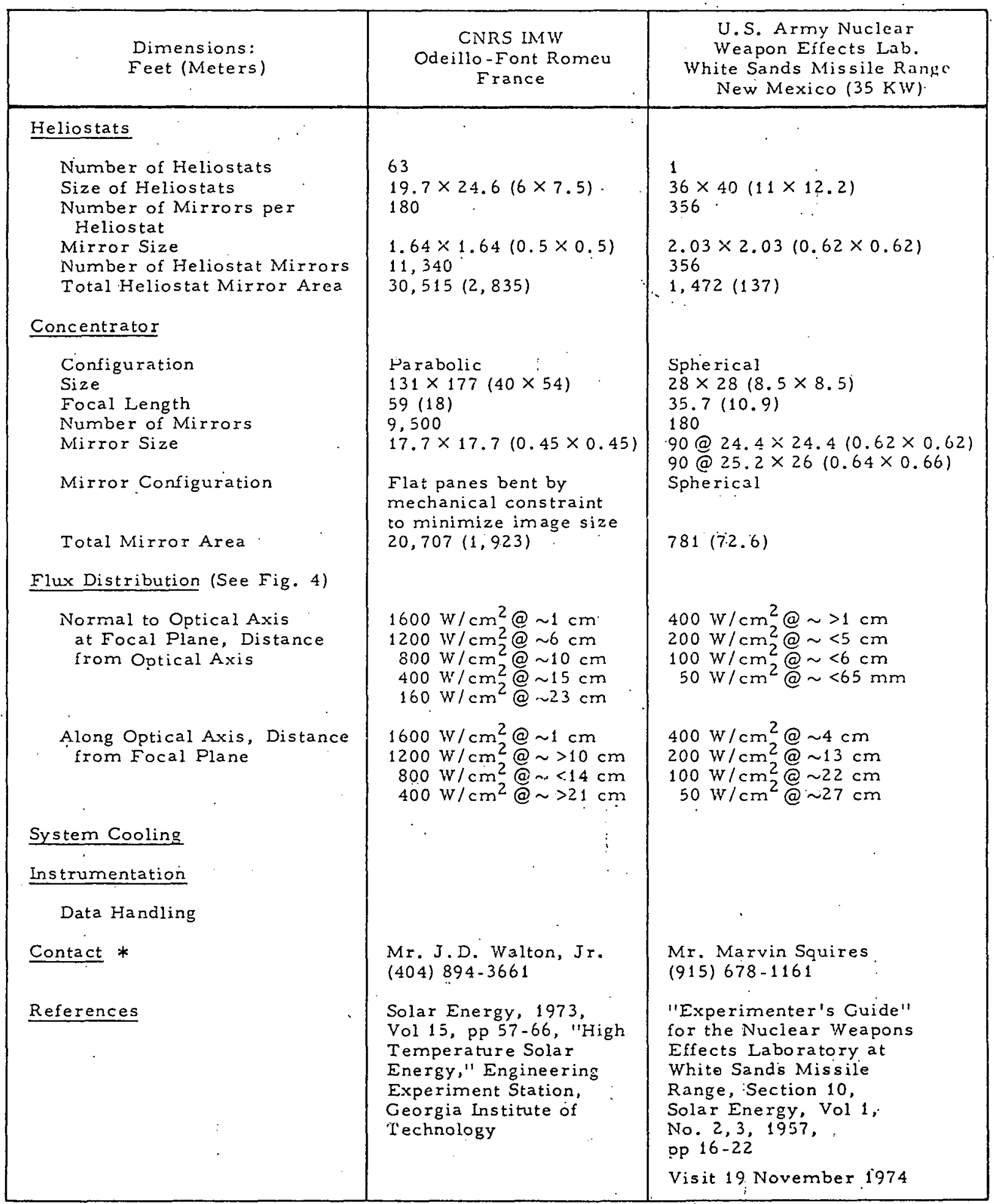

* The iridividual listed provided most of the information listed and is not necessarily associated directly with the ownership or operation of the facility. 


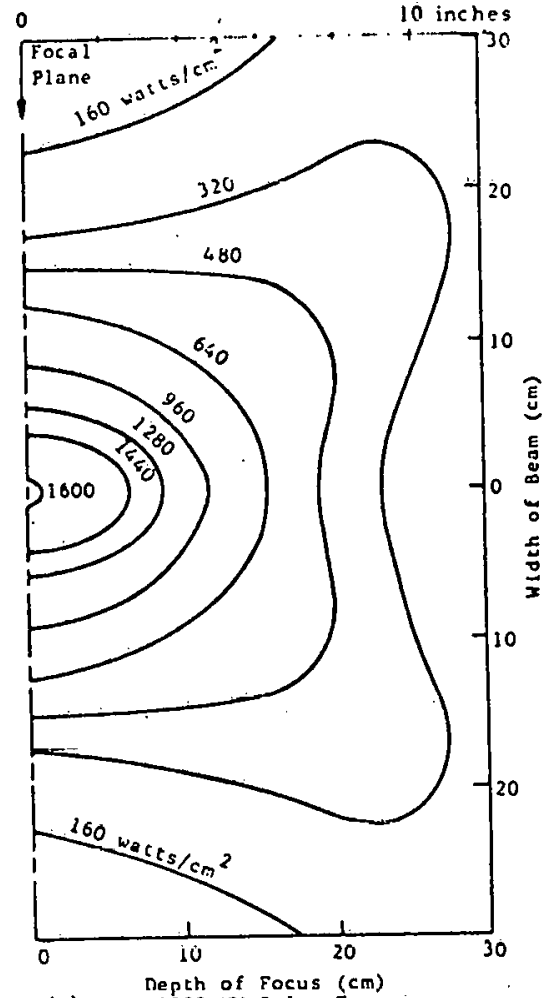

(a) CiNR $1000 \mathrm{KW}$ Solar Furace

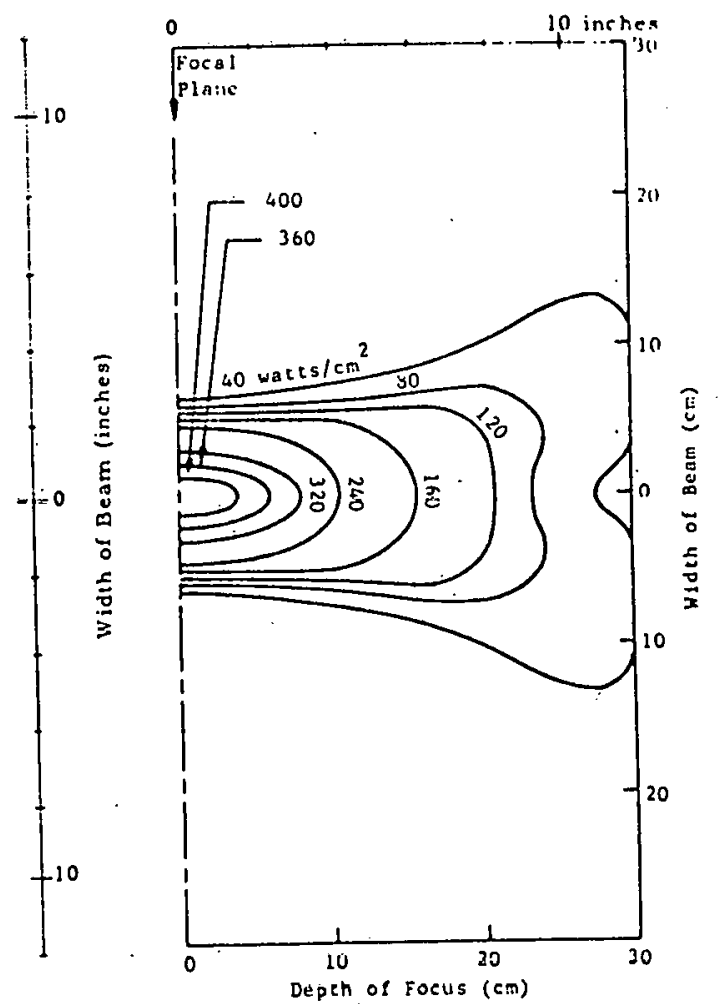

(b) U. S. Amy $35 \mathrm{NW}$ Solar Furnace

Figure 4. Image contours in Horizontal Plane

Table V. Solar Simulators

Tábie $V$. Soláp Simulâtórs

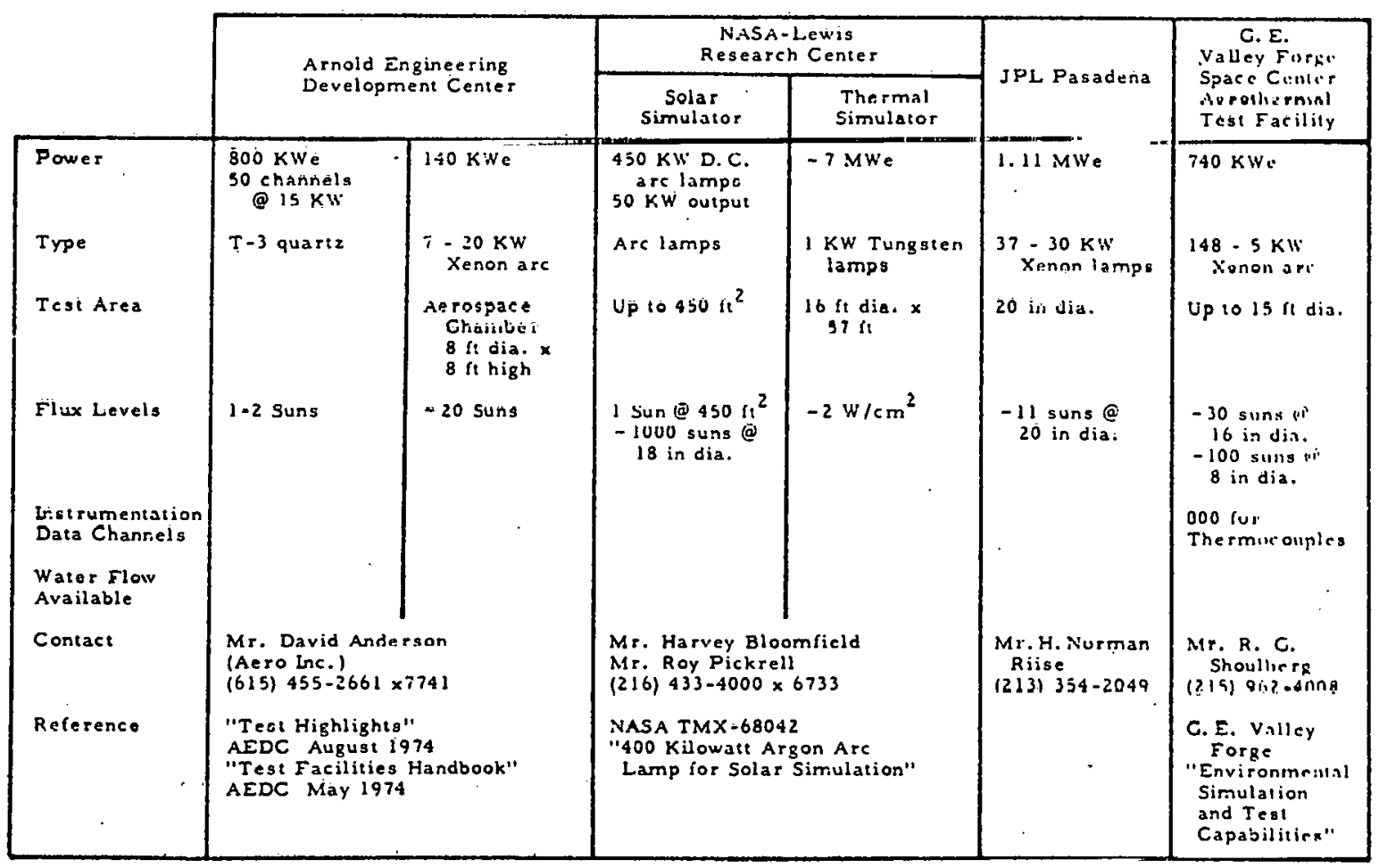


designs. Therefore, these large radiant heat facilities serm to offer a compromise of capabilities for testing the largo components or modules of the proposed receivers. Table VI summarizes characreristics of the radiant heat facilities identified in this report. Additional information may be found in sections 3.1.7 through 3.1.10. 
Table VI. Radiant Heat Facilities

\begin{tabular}{|c|c|c|c|c|c|c|}
\hline . & $\begin{array}{c}\text { Sandia labaralories } \\
\text { Albuquerque, New Mexico }\end{array}$ & $\begin{array}{c}\text { NASA riliglit Researci Centur } \\
\text { Edwards. Califorria }\end{array}$ & $\begin{array}{c}\text { USAF Flight Dynamica Lab. } \\
\text { Wright Patrerson AFB } \\
\text { Dayton, Dlio }\end{array}$ & $\begin{array}{l}\text { MeDonzell Aircraft Co. } \\
\text { St. Louis, Missou=i }\end{array}$ & $\begin{array}{l}\text { NASA J.S.C. } \\
\text { Houston, Texas }\end{array}$ & $\begin{array}{l}\text { Rockwell International } \\
\text { Downey. California } \\
\text { (NASA J.S.C. Ounc.d1 } \\
\end{array}$ \\
\hline \multicolumn{7}{|l|}{ Power } \\
\hline Steady State & $5 \mathrm{MWe}$ & $\begin{array}{l}2.3 \mathrm{MWe} \text { (Anald Controller) } \\
5 \mathrm{MWe} \text { (day) } \\
20 \mathrm{MW} \text { (night) } \text { Digital Contr. }\end{array}$ & $23 \mathrm{MWe}$ & 7.5 mive & $5 \mathrm{NWC}$ & 5 Mive \\
\hline Peak Translent & $\begin{array}{l}20 \mathrm{MWe} \text { for } 40 \text { oec } \\
\text { leranstormer limịtedl }\end{array}$ & $\begin{array}{l}\text { "Significant overload can be } \\
\text { tolerated far short periouls" }\end{array}$ & $50 \mathrm{~N}$ We for $5 \mathrm{~min}$ & $\begin{array}{l}34.5 \mathrm{Mwe} \text { for } 60 \mathrm{sec} \\
\text { (transformer limited) }\end{array}$ & $?$ & $?$ \\
\hline $\begin{array}{l}\text { Total Delivered to Test } \\
\text { Area }\end{array}$ & $?$ & $?$ & $?$ & $4.5 \mathrm{sw} / \mathrm{h}$ & $?$ & $?$ \\
\hline Radiator Typeiol & $\begin{array}{l}\text { T-3 Ouartz Lamps } \\
\text { Graphite radian! }\end{array}$ & T-3 Quartz Lanps & $\begin{array}{l}\text { Quarte Lampo } \\
\text { Graplite radiant }\end{array}$ & $\begin{array}{l}\text { T-3 Ourirl= Lamps } \\
\text { Giraplite =adiant }\end{array}$ & $\begin{array}{l}\text { T-3 Ouartz Lamps } \\
\text { Graphite ratliant }\end{array}$ & 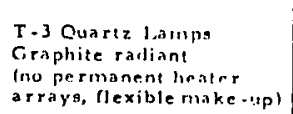 \\
\hline $\begin{array}{l}\text { Maximum Flux Denolty at } \\
\text { Teat (Steasly State) }\end{array}$ & $\begin{array}{l}>100 \mathrm{~W} / \mathrm{cm}^{2} \text { (Quartz) } \\
>400 \mathrm{~W} / \mathrm{cm}^{2} \text { (Graphite) }\end{array}$ & $>100 \mathrm{~W} / \mathrm{cm}^{2}$ (Cuarth) & $>100 \mathrm{wicm}^{2}$ & $\begin{array}{l}-100 \mathrm{~W} / \mathrm{cmo}^{2} \text { (Quarez) } \\
>500 \mathrm{~W} / \mathrm{cr})^{2} \text { (Graphite) }\end{array}$ & & \\
\hline 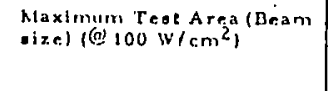 & $\begin{array}{l}\text { Power limiled, "test itemb } \\
\text { up to } 17 \text { " high can be } \\
\text { accommodated" }\end{array}$ & $\begin{array}{l}\text { Power limiled, test area } \\
150^{\circ} \times 120^{\circ} \times 40^{\prime} \mathrm{high} \\
\left.110^{\circ} \times 10^{\prime} \mathrm{ha} \% \mathrm{beg}, 1 \mathrm{gedl}\right)\end{array}$ & $?$ & "up to $32 \mathrm{r}^{2} \mathrm{u}^{2}$ (power li rited) & $\begin{array}{c}-5 n 1^{2} \\
6 . \times 8\end{array}$ & \\
\hline \multicolumn{7}{|l|}{ Flux Distribution Cantrol } \\
\hline $\begin{array}{l}\text { Number of Beam } \\
\text { Sulsections }\end{array}$ & $\begin{array}{l}8 \text { channela of } 3 \text { phase } \\
\text { Ignitron Tube Canirolters }\end{array}$ & $\begin{array}{l}\text { 24 with Analog Contrallers } \\
\text { IInnitron power regulators) } \\
\text { S12 with Digital Controllers } \\
\text { (Solid State SCR) }\end{array}$ & $\begin{array}{l}\text { Grid Flux Contrel } \\
80 \text { channels of } 580 \mathrm{KVA} \text { each } \\
\text { Ignitron Power Controlters }\end{array}$ & $\begin{array}{l}3 \text { channels of "E" Ignitron } \\
54 \text { clianne!: of "B" Ignitron } \\
57 \text { Total-Se parate Cont ool }\end{array}$ & 22 heater channelels & $\begin{array}{l}\text { 36 stationary channel, } \\
\text { of t40 Amp } 4 \$ 0 \text { volis }\end{array}$ \\
\hline Flux Uniformity/Subsection & $?$ & $?$ & $?$ & $?$ & $?$ & ? \\
\hline Flux Variabillty/Subsection & $?$ & Zero to maximu:m, val:s:s & $?$ & Zero to maxitnum per heater & $?$ & $?$ \\
\hline $\begin{array}{l}\text { Flux Rale of Variation/ } \\
\text { Subsection }\end{array}$ & $\begin{array}{l}\text { For T-3 Quartz Lamps: } \\
\text { to } 75_{i 0}^{\circ} \text { adiation in } 2-3 \text { sec } \\
\text { cn: to } 10 \% \% \text { radiation in } \\
2-3 \text { sec ofl }\end{array}$ & $?$ & $?$ & 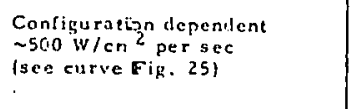 & $?$ & ? \\
\hline Calibration Nethod & $?$ & $\begin{array}{l}\text { The rnocauple, feechark } \\
\text { lieat fllux yensor icedtack }\end{array}$ & $?$ & $\begin{array}{l}\text { Thermoco:wle feedback } \\
\text { Heat Ilux \&-nsur fer:dback }\end{array}$ & $?$ & ? \\
\hline \multicolumn{7}{|l|}{ Heat Manageinent } \\
\hline $\begin{array}{l}\text { Working Fluid Flow/ } \\
\text { Quality }\end{array}$ & $?$ & $\sim 25 \mathrm{gpm}$ & $\begin{array}{l}\text { Demine ralizing plant, } 2 \text { bed } \\
\text { system deaigned for contin- } \\
\text { uous operation of } 40 \mathrm{kpm}\end{array}$ & $\begin{array}{l}300 \mathrm{gpm} \text { e } 80 \mathrm{psi} \\
120 \mathrm{gpm} 1000 \mathrm{psi} \\
\text { Recirculate costitioned rater } \\
\text { Pumpo-thruheat exchianger }\end{array}$ & ? & $?$ \\
\hline $\begin{array}{l}\text { Cooling Syotem Flow/ } \\
\text { Heat Rejection }\end{array}$ & 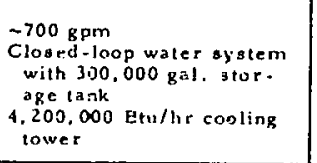 & $\begin{array}{l}\text { Air Circulation -ns specific } \\
\text { heat rejection system } \\
\text { identified }\end{array}$ & 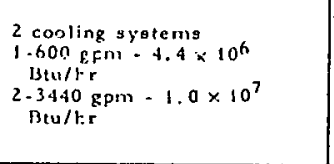 & $\begin{array}{l}\text { Heat exchalger - tulse/t: nk } \\
\text { intake from water main - } \\
\text { discharge is sewer }\end{array}$ & $\begin{array}{l}\text { Heat exchanger } \\
\text { sygtem tor heat } \\
\text { rejection in alti. } \\
\text { tude chamber }\end{array}$ & $\begin{array}{l}\text { Cooling tower } \sim 100 \mathrm{psi} \\
\text { and } 200 \mathrm{gpm}\end{array}$ \\
\hline
\end{tabular}


Table VI. (Continued)

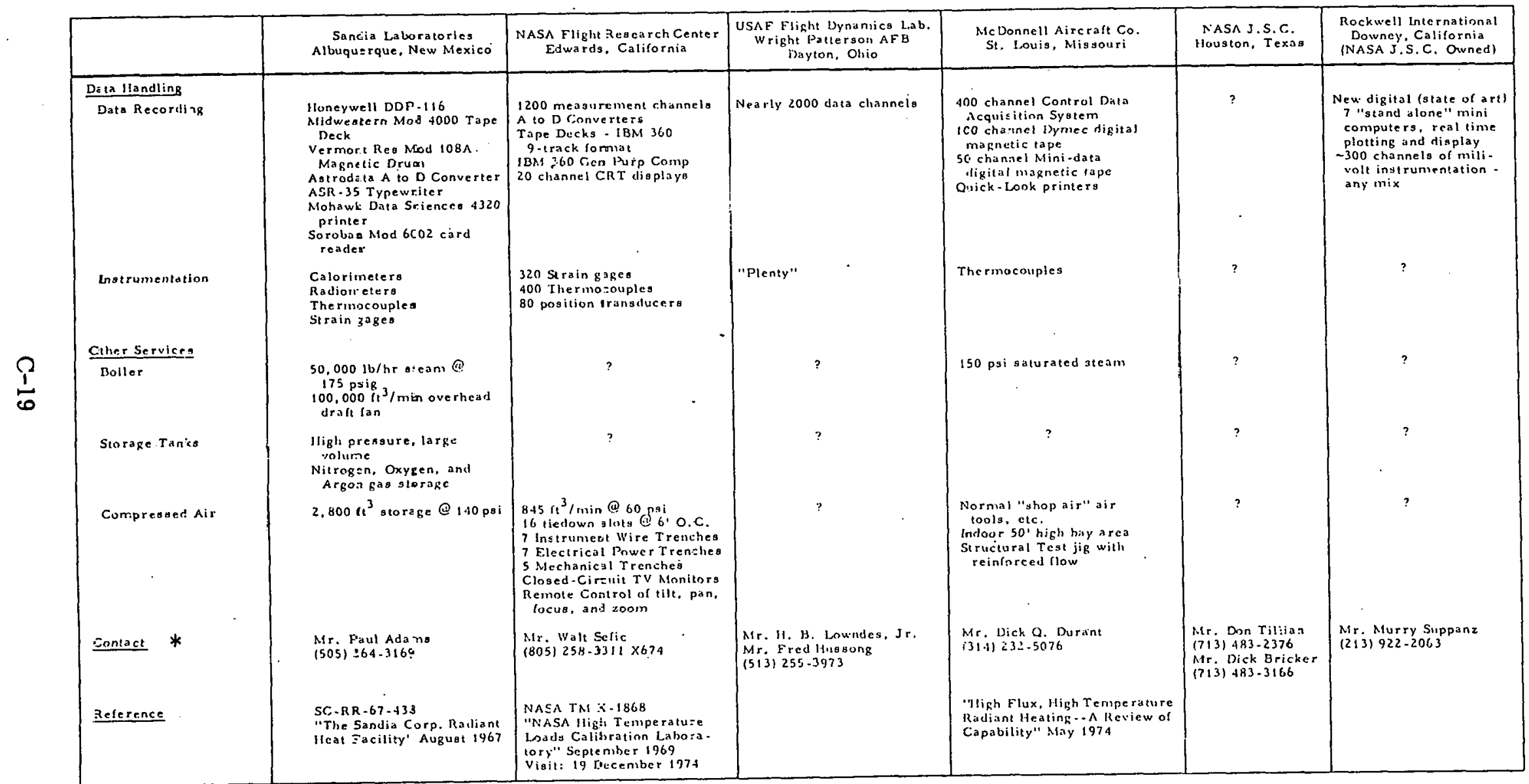

* The indivicual listed provided most of the information listed and is not necessarily associated directly with the ownership or operation of the facility. 
The French solar furnace is located in the pyreness at odeillo-Font Romeu (altitude, 5900 feet), about 20 miles east of Andorra. At this location the sun shines as many as 180 days a year and solar intensities as high as 1000 watts fer square meter are common. The solar furnace was completed in 1950 at a cost of about $\$ 2,000,000$.

The parabolic reflector has a focal length of 59 feet 118 meters), is 130 feet high and 175 feet wide, and is composed of 9500 mirrors 17.7 inches by 17.7 inches $(1 / 2 \mathrm{~m} \times 1 / 2 \mathrm{~m})$. Since the parabolic reflector is too large to track the sun. 63 smaller mirrors (heliostats) set in eight tiers are used to follow the sun and reflect its ray in parallel beamis onto the parabola. The heliostats are 24.6 by 19.7 feet and each is composed of 180 mirrors 19.7 inches by 19.7 inches.

The movement of cach heliostat is automatically guided by electronic controls operated by $r \in f l e c t \in d$ rays. The accuracy of the control is $1 \mathrm{~min}$ of arc, but due to dispersion on the flat glass, 5 min of arc are obtained on the reflected rays.

A solar beam of constant energy is directly horizonatlly southward to a caraboloid reflector of $1923 \mathrm{sq} \mathrm{m}$ intercepted area. This paraboloid contains 9500 single glass panes, bent by mechanical constraint and adjusted to reflect maximum radiation to the focal plane, situated $18 \mathrm{~m}$ from the apex of the parabola. The precise adjustment of these two devices, completed on October 1 . 1970 took about two years.

Results of tests concerning the energy received at the focal image are as follows:

(1) The energy collection rinsply agreps with calculations, taking into account the factors of reflectivity of glass, and the dispersion due to imperfect curvature of mirrors and to shading. (2) power beyond $1000 \mathrm{~kW}$ was obtained with the device, when the incident solar energy was more than $0.1 \mathrm{w} / \mathrm{sq} \mathrm{cm}$. (3) The energy concentration in the center of the focus-image is equal to black-bcdy radiation around 3800 degrees $C$.

The orientating device (Collector subsystem, Figures 5 \& 6 ) consists of 63 independent heliostats which are automatically operated by photoelectric control of their reflected rays. The driving parts, electronically coupled with the photoelectric control. are hydraulic. A reservoir of oil under fressure (Figure 6, point C) furnishes the hydraulic azimuth activation of the heliostats.

Each heliostat collecting surface, which is $45 \mathrm{sq} \mathrm{m}$, is made of 180 flat glass panes, back-silvered and covered with copper and varnish.

It should be noted that the vitreous reflection. which is important above some value of the inclination of the incident rays, correctly shares in the lighting of the paraboloid. 
Furthermore, the arrangement of heliostat positions appropriat $\Omega 1 y$ accou ts for the apparent diameter of the sun. In such a way a reflected beam which is homogeneous and equivalent to that which would be given by only one large orientator can be achieved.

Figure 7 gives the distribution of the flux density on a vertical piane located $18 \mathrm{~m}$ from the apex of the paraboloid. The value $\underline{\mathrm{d}}=17 \mathrm{~cm}(6.6$ inches $)$ represents the diameter of the image of the sun given by a mirror of low aperture (Gauss image) near the focal axis. The energy scanning of the geometrical focal vertical plane on an east-west line across the focal axis gives the profile of distribution shown in Figure 8 (curve 0). Behind this plane a considerable decrease in the heat flux density is noticed (curves at the distances $\underline{d} / 2$ and $\underline{d}$ from the focal plane, Figure 8).

Since the paraboloid is truncated at the bottom, the energy distribution at the focus comes chiefly from the side and upper parts of the reflecting area. 


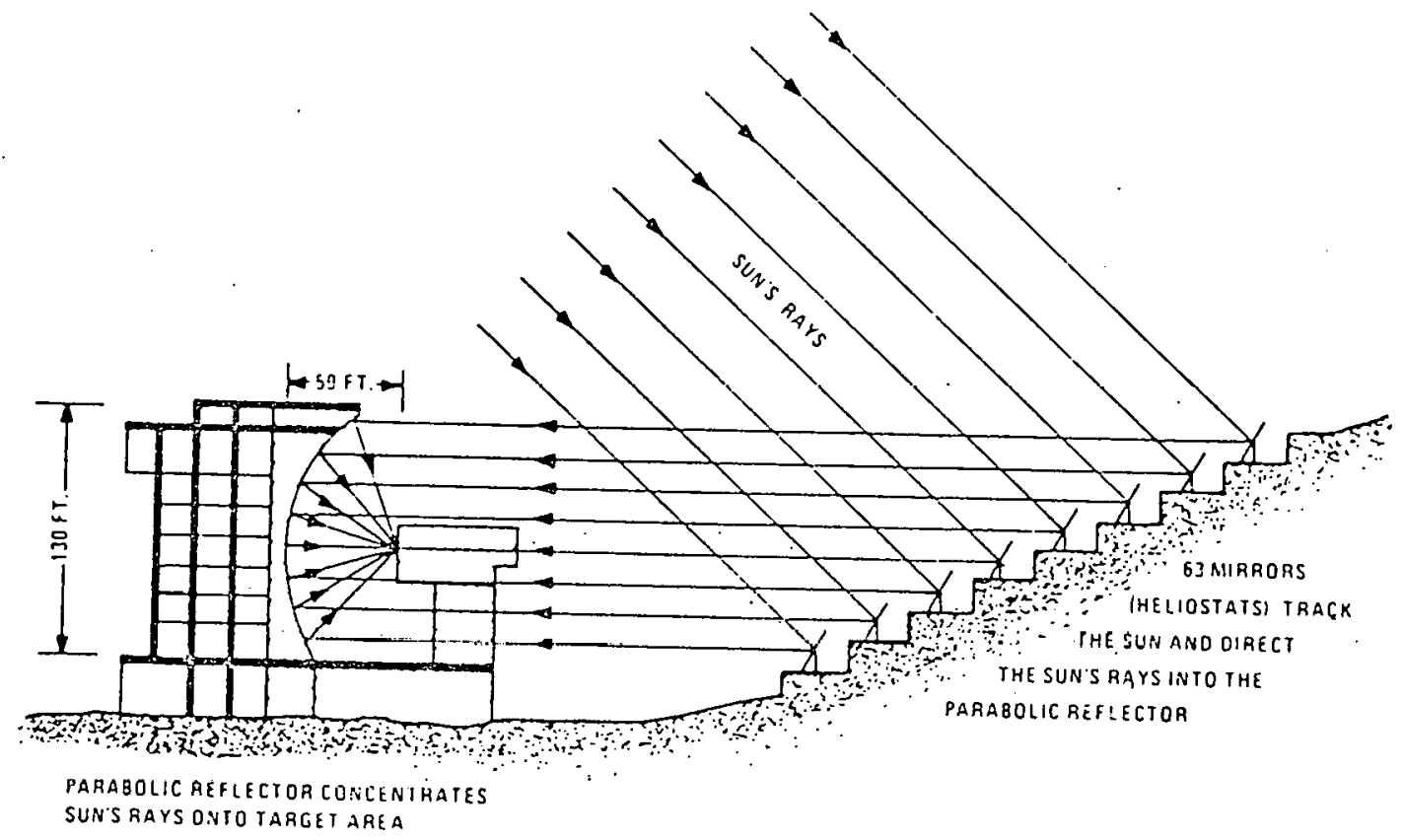

Figure 5. Schematic of $1000 \mathrm{kw}$ Solar Furnace
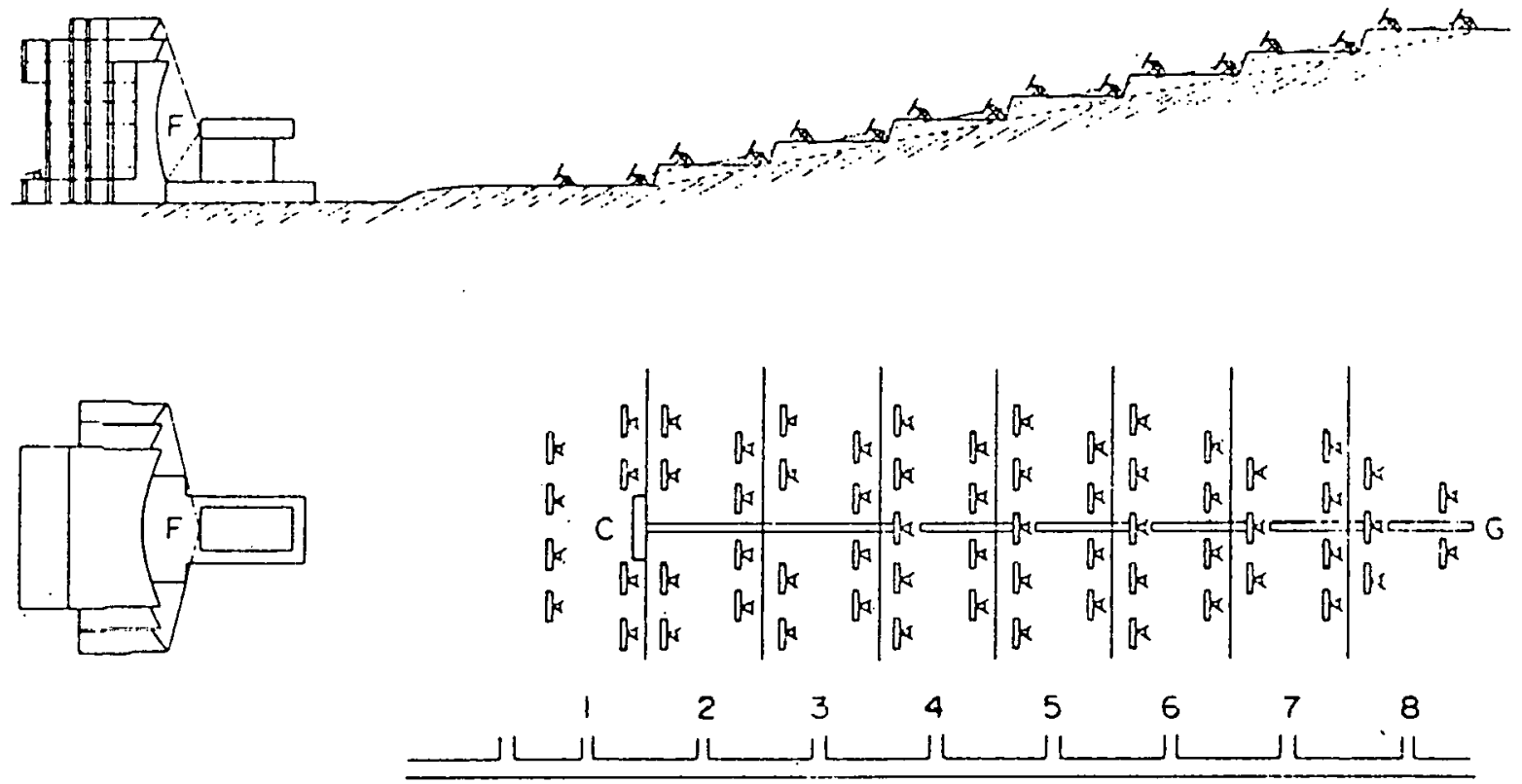

Figure 6. Solar Furnace Scheme 


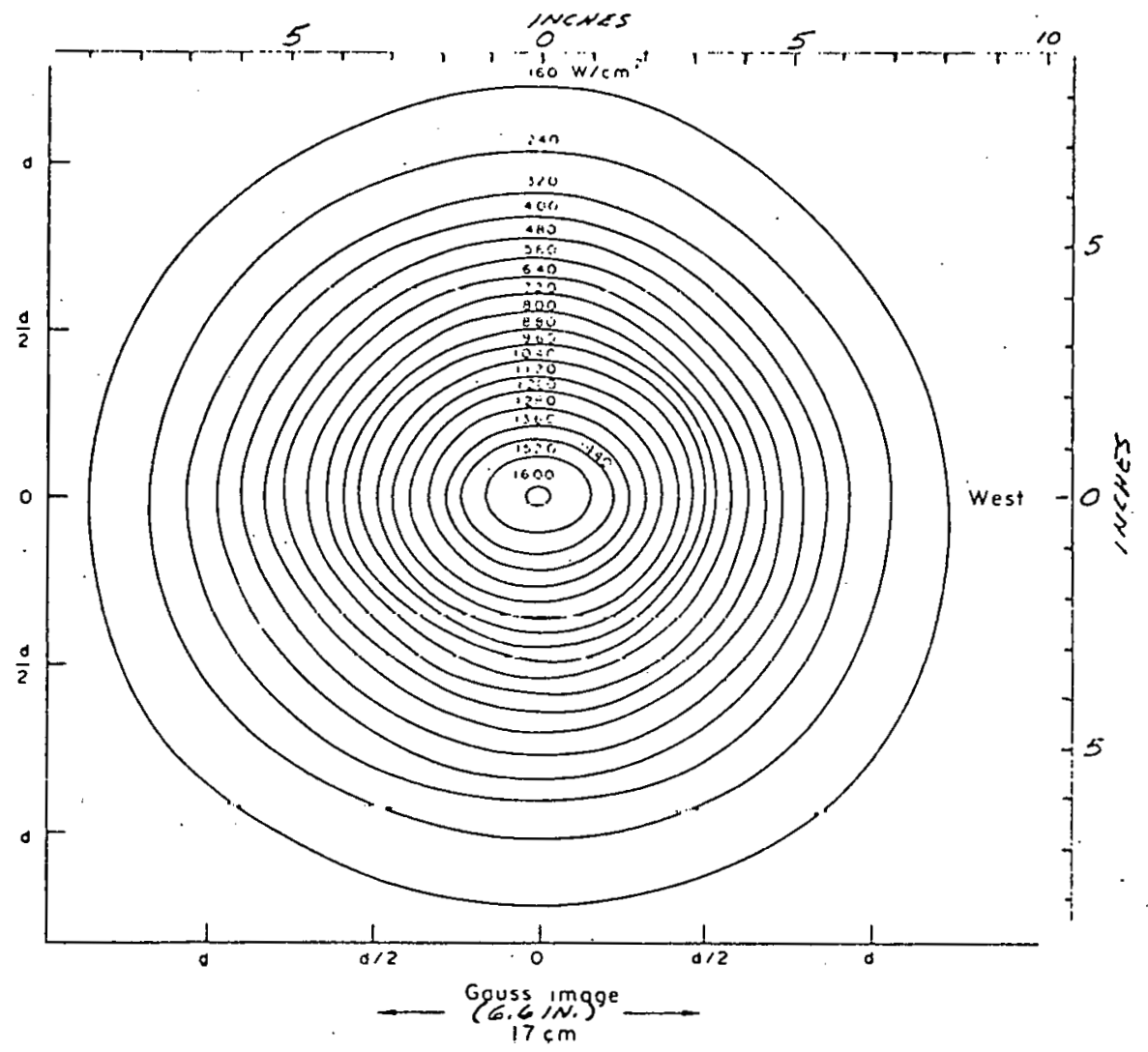

Figure 7. Distribution of Heat Flux Density on a Vertical flane

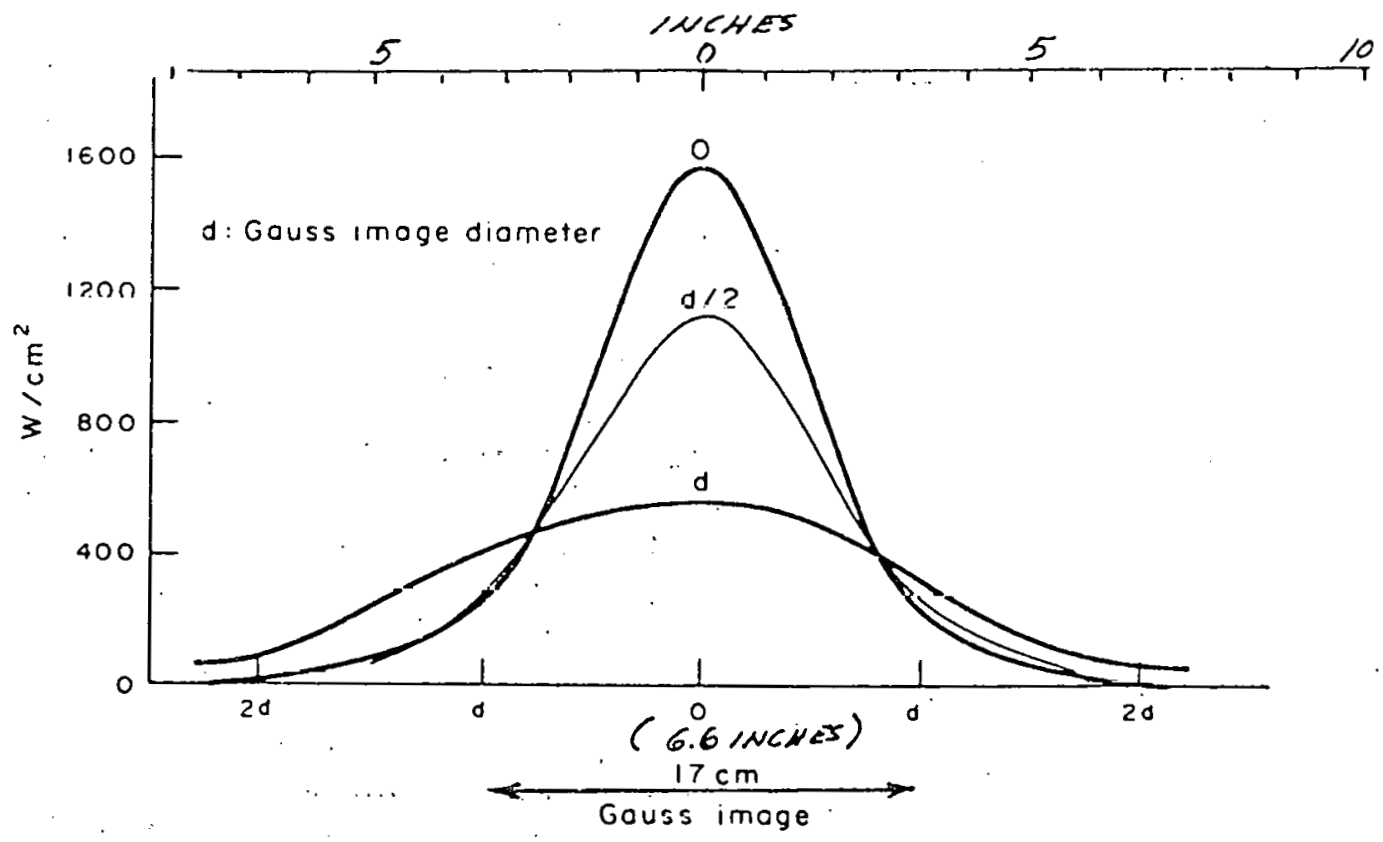

Figure 8. Profile. of Heat Flux. Density 


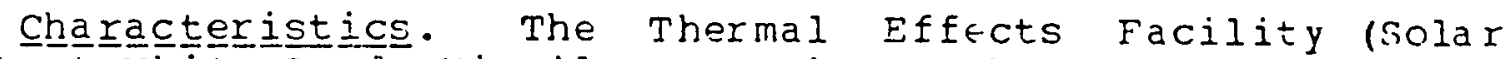
Furnace) at white Sands Missile Fange $i s$ a solar furnace of thr. focusing type which utilizes an effective aperture to focal length ratio of less than one. It consists of four main components: the heliostat, the attenuator, the concentrator, and the control and test chamber. The heliostat consists of 356 mirrors, each 2 feet by 2 feet mounted on a steel frame 40 feet wide and 36 feet high. In operation, it reflects the sun's rays to the concentrator. The concentrator consists of 180 sphrical mirrors, each affroximately 2 feet by 2 feet and mounted on a steel frame. 30 feet by 30 feet and 10 cated 96 feet south of the heliostat. Each mirror comprising the concentrator is individually focused to concentrate the sun's rays at the same point on the focal plane, which is located inside the test and control chamber. The attenuator which is located between the $t \in s t$ and control chamber and the concentrator consists of a louver structure whose blades can he a juster to regulate the amount of sunlight reaching the concentrator. The test chamber which is eight feet by eight feet in cross-section normal to tho parallel sunrays from the heliostat and 16 feet in length. contains the controls for the heliostat and the attenuator. The control chamber also contains the controls for the exposure shutter for exposures as short as 0.1 second and for the slow water-cooled shutter designed to protect the exposure shutter until just before the exposure is made.

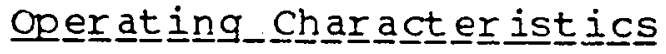

Flux levele . The thermal flux at the focal plane of tho solar furnace depends primarily on the amount of reflected sunlight reaching the concentrator. This quantity is controlled by the attentuator. The attenuator is operated from the control chamber. The image of the sun at the focal plane is a fproximately four inches in diameter. The maximum flux ottainable at the center of the image is $100 \mathrm{cal} / \mathrm{sq} \mathrm{cm}$ per second (approximate].y $420 \mathrm{~W} / \mathrm{sq} \mathrm{cm}$ ) at the focal plane. Larger exposuro areas can be obtained, but at lower flux levels by defccusing; i.e., moving away from the focal plane.

Pullse widith. The solar radiation pulse at the focal plane is determined by the exposure shutter. The length of tims the exposure shutter stays open is preselected by the oferator at the control console. In addition to the fast shutter, a pulso shaper can be swung into position in the converging beam about 40 inches in front of the focal plane. The pulse shaper consists of an array of 16 radial vanes, each $1-1 / 2$ feet long. These vanes are driven at variable speed by a specially constructed cam controlling the irradiance at the target. It modifies an otherwise rectangular pulse at the focal plane into shaped thermal pulses corresponding to the range of nuclear weapons from $25 \mathrm{kt}$ to the megaton range. There is some variation in shape over this range because of the acceleration of the vanes necessary to produce this shape. 


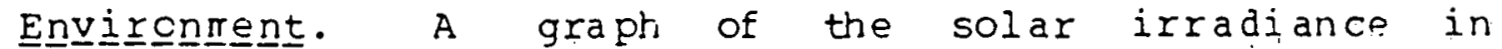
calories/sq cm per second as a function of distance from thr image center at the focal plane is shown in Figure 9. This araph was obtained using a radiometer at the solar furnace's former location at Natick. Massachusetts.

Size of Experiments. Because of the small exposur? vclume of the test chamber, the dimension of the test item along the focal plane of the solar furnace cannot be greater than a fproximately four feet. Instrumentation cables may be brought out of the test chamber through conduits provided for that purpose.

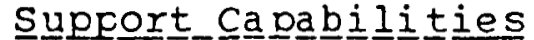

Staffe. The primary purpose of the white sands Thermal Facility is to frovide a source of radiation for experiments designed to investigate radiation effects on materials and components of interest to the Department of Defense. Facility personnel will operate the solar furnace and provide full operational support. The on-site professional staff is readily available to the experimenter for consultation.

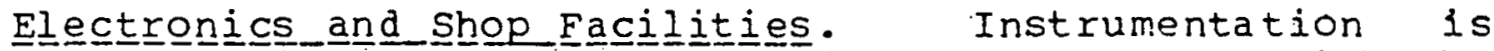
a vailable to experimenters through previous arrangements with the technical coordinator. Also, a machine shop and the services of a machinist are available for needs that may arise during the course of the experiment or through previous arrangement.

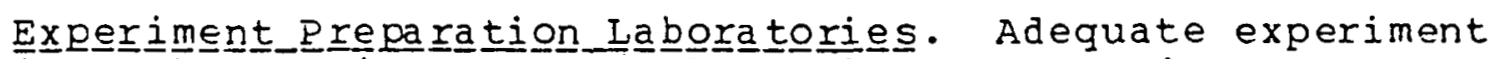
preparation labcratories, personnel offices, security storage, radioactive storage, radiation chemistry laboratories, and conference rooms are available at the site. 


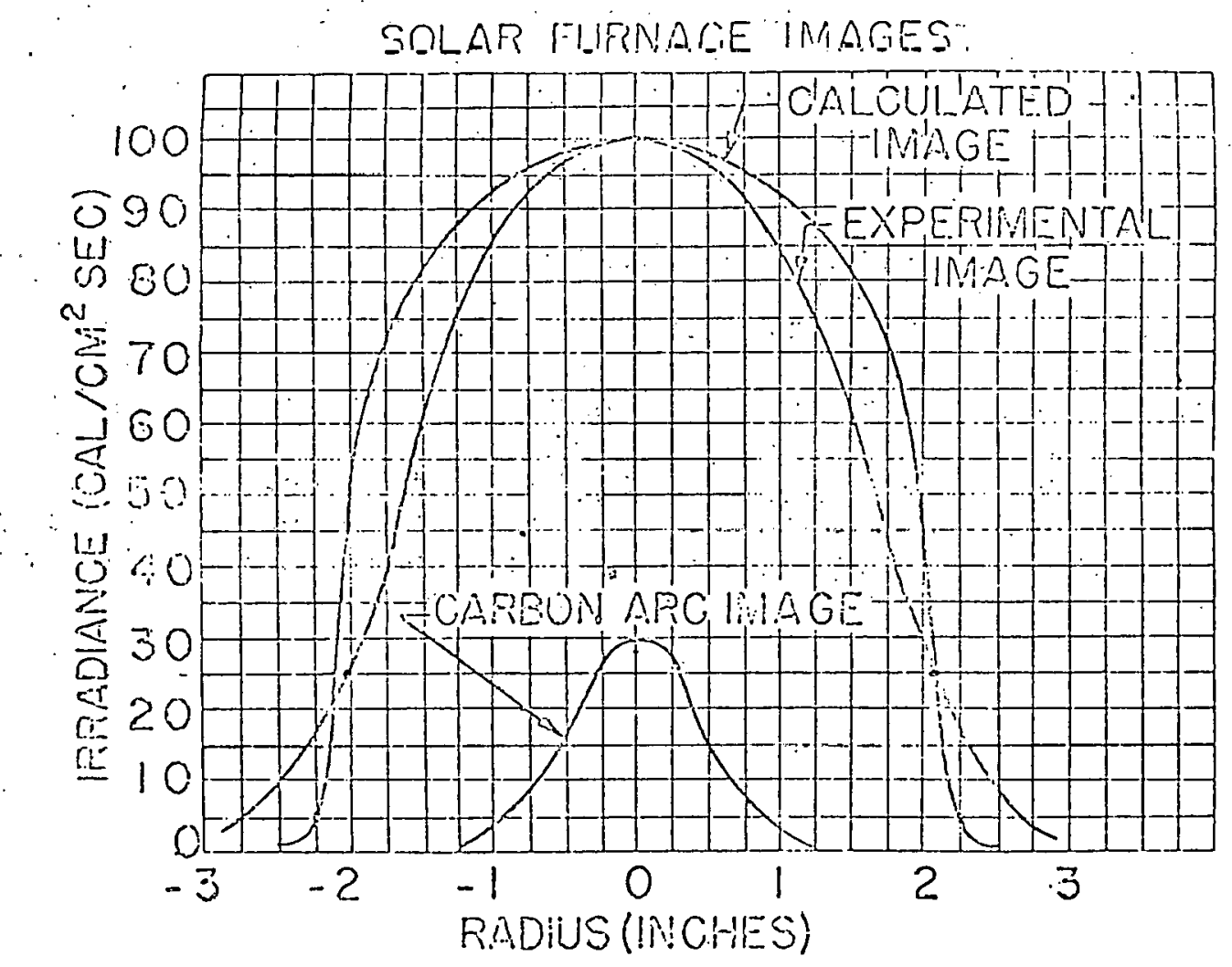

Figure 9. Irradiance Profiles at Eest Image Position 
AEDC has several solar simulators. The one of some. interest to the receiver test experiments is a 140 KWr device with an efficiency of approximately $40 \%$, delivering approximately 54 kWth to the test surface. This simulator could froduce, through an optical concentration system, approximately 20 solar concentrations at best. The other simulators do not have the concentrating capability even though the largest is of approximately 800 kwe which produces low flux levels (1-2 solar concentrations).

The solar simulator is an off-axis, integrator system producing a well collimated and uniform beam over an 8-ft-diam by 8-ft-high test volume. The intensity within the tost volume is one solar csristant with a uniformity of \pm 5 percent and a decolilimation of $\pm 1.8 \mathrm{deg}$. The energy spectrum is typical of the 20-kw xenon short-arc lainp, seven of which are located in thr source array. This spectrum is very similar to that of the sun except for an excess of energy in the near infrared. The simulator spectrum can be adjusted to more closely match the solar spectrum by filtering and by addition of $5-k w$ mercury-xenon lamps to the source array.

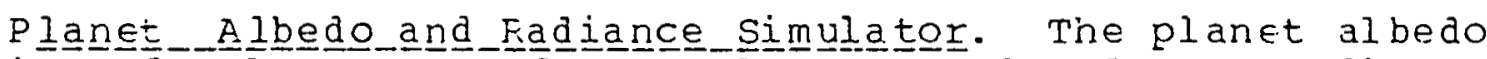
(reflection of solar energy from a planet) and flanet radiance are simulated by one system with as many as 1500 T-3 guartzenvelope tungsten filament lamps mounted in individual reflectors which may be spaced around the test article to irradiate it to the desired amount.

Each lamp has an output continuously adjustable from 0 to approximately $24 \mathrm{w} / \mathrm{sg}$ ft at a aistance of $30 \mathrm{in}$. in front of the lamp reflector unit. This output is to within \pm 5 percent and extends approximately \pm 40 deg. to each side of the output centerline, The lamp units may be installed in multiples to further increase the level of the radiant enfrgy. The lamps may be grouped in banks, each with its individual control circuit, so that the desired distribution of energy can be achieved cn the vehicle surface. There are 50 channels of control circuits, each capable of delivering up to $15 \mathrm{~kW}$.

The simulator units are attached to a birdcage arrangement surrounding the test vehicle. The birdcage is supported by the article handing system and is adjusted and tailored to adapt to different test article shapes, sizes, and $r \in q u i r e m e n t s$. 


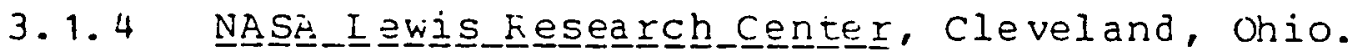

NASA LEwis has both a solar simulator and a thermal simulator. The solar simulator is housed in the space power facility chamber, $120 \mathrm{ft}$. high and $100 \mathrm{ft}$. in diameter (se? Figure 10_) and is capable of radiating a.450 sq. ft. area with approximately the flux of one sun. By employing a focusing mirror, the flux level of approximately 10 suns can be achieved. other focusing devices would have to be obtained to reach the 500 to 1000 times solar flux desired. With a nominal output level of approximately $50 \mathrm{KWth}$, the resulting test area would be about $1 / 2$ sq. ft. if the radiation were uniformly distributed. The thermal simulator has about 7 Mwe input power for $1 \mathrm{~kW}$ tungsten 1 amps mounted in aluminum. This unit was configured in a $16 \mathrm{ft}$. diameter by $57 \mathrm{ft}$. high, can be altered for various shapes, but is currently non-operational with little hope that it would be available.

Figure 10. Space Power Facility Solar Simulator 


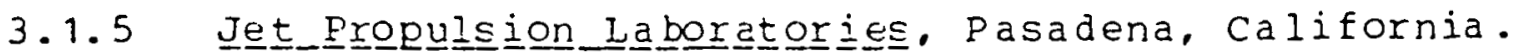

JPL has a solar simulator using 37-30 KWe xenon lamps. The radiation is directed through an optical "mixor" to 20 inches in diameter. producing approximately 11 solar concentration. Details and description of this facility were not available a. the time of publication of this documert. 
The major comfonent of the Space Environment Simulation Laboratory is the 54 -feet high by 32 -feet diameter solar-thermalvacuum chamber. Capable of accommodating complete spacecraft up to 21 feet in diameter weighing as much as 44.000 counds, thr space chamber frovides vacuum conditions from 10 to the minus 6 to. 10 to the minus 9 Torr and the cold black characteristics of space. The interior surfaces of the solar-thermal-vacuum chamber are maintained at extremely low temperatures to simulate the low energy, completely absorbing characteristics of stace. A system of black cooling fanels is employed through which jiquid nitrogen is circulated. (See Figure 11 and Table VII).

All surfaces facing a test vehicle have an emissivity of 0.95 or higher. The cyrogenic panels are arrayed as shown in the schematic diagrain and are covered with a thref-quarter inch thick hone ycomb. The baffle effect of the finned array combined with the multiple bounce path of the honeycomb produces the high emissivity. The off-axis design of the collimator affords simulation of the "cold, black, sface" characteristics.

Energy radiated from a test spacecraft to the collimating mirror is reflected to the cold chamber walls rather than reradiated back tc the spacecraft.

Radiation of about 30 solar constants occurs at the leris which covers a 16 inch diameter. Conceivably this can be reimaged to achieve 100 solar constants on an 8 inch diameter area.

The GE Solar Simulator uses Xencn compact arc lamps as the source of radiant energy. Xenon, traditionally, is used as the best practical source for solar simulation. A comparison of the irradiance cf the Xenon simulation and the air mass 2 sun is tabulated below:

$$
\begin{aligned}
& \text { Wavelength Band }
\end{aligned}
$$

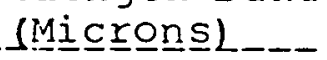

$$
\begin{aligned}
& 0.25-0.40 \\
& 0.40-0.70 \\
& 0.70-1.10 \\
& 1.10-1.50 \\
& \text { 1. } 50 \text { - }
\end{aligned}
$$

Air Mass Two

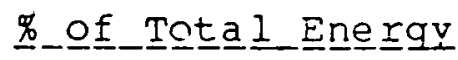

$$
\begin{array}{r}
2.67 \\
44.30 \\
36.15 \\
9.55 \\
-10 \frac{7}{10} \div \frac{3}{3} \frac{3}{0 \%}
\end{array}
$$

G.E. Simulator

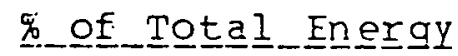

5.3

30.8

41.7

11.5

$-\frac{10}{10} \frac{0}{0} \cdot \frac{5}{0}$ 


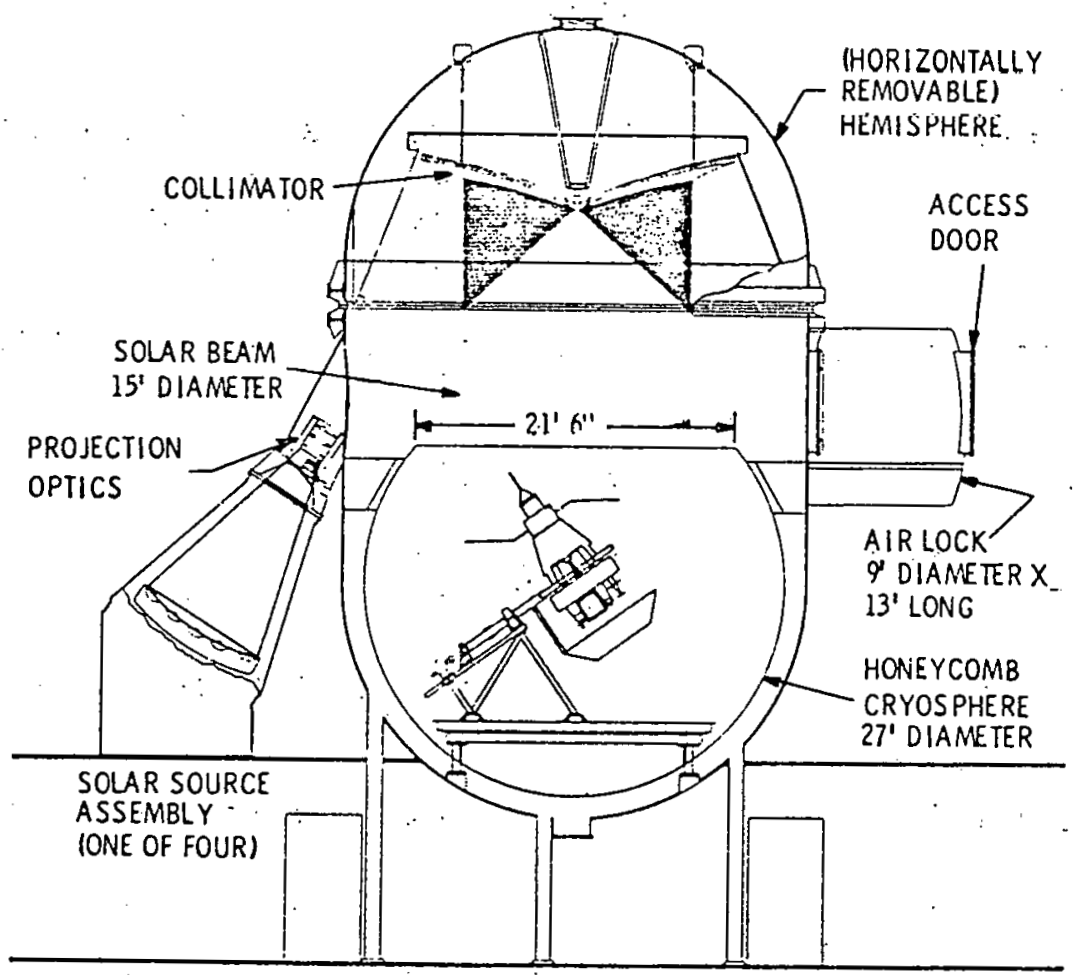

FIG. 11. Space Environment Simulation Laboratory 
TABLE VII

SOLAR-THEFMAL-VA.CUU: CHAMBEF

\section{CHARA}

VACUUM CHAMBEF

Si ze

Cylinder. $32 \mathrm{ft}$. diameter by $54 \mathrm{ft}$. high

Access

Upfer hemisphere removable - door in side. 40 in. by 84 in.

Material

$304 \mathrm{~L}$ stainless steel $3 / 4$ in. thick

Vacuum

10 to the minus 5 to 10 to the minus 9 Torr

VACUUM FUMPING

Cryogenic

100 degrees $K$ condensables (LN2)

$3.4 \times 10$ to the eighth 1 iters/ second

20 degrees $k$ condensables (GHe)

$2.3 \times 10$ to the sixth 1 iters/second

Oil Diffusion

Non-condensables (He, H2, Ne)

20,000 . liters/ second

WALL EMISSIVITY

$0.90-0.95$

SCLAK SIMULATION

15-ft. diameter

Source

$1485 \mathrm{kw}$ xenon arc lamps

collimator

off-axis quadrisected glass mosaic faraboloid

collimation

+3 degrees to +5 hegreps

Intensity

120 watts/sq. ft. (feedback control)

Uniformity

$\pm 15 \%$ (volume and plane)

Mainten ance

Lamps replaceable during operation

TEST CAPABILITY

Size

21-ft. diameter by $30 \mathrm{ft}$. high

We ight

44,000 pounds

OFERATING TIME

startup

7 hours to 10 to the minus 7 Torr

Shutdown and warmup 20-24 hours

INSTRUMENTATION

800 channels for thermocouples 


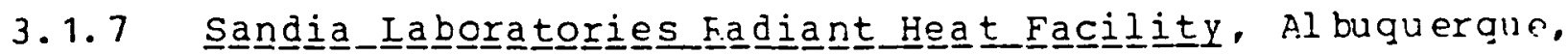
New Mexico.

The Sandia Radiant Heat Facility is part of a hightemperature testing complex located in the sandia Laboratories Remote Test Area. The facility was built to provide laboratory simulation of high-temperature environments on large assemblies. $A$ wide range of thermal envirsnments has been simulated: from high-level, short-duration programs simulating the thermal energy from a nuclear burst or launch pad abort fire; to intermediatelevel and long-duration programs simulating transfortation accident fires; to low-level, intermediate-duration programs simulating aerodynamic heating. The name, Radiant Heat facility. comes from the fact that the radiant thermal energy is used as the primary mode of heat transfer. In the simulation of aerodynamic heating, no attempt is made to reproduce the mass flow effects.

The facility has eight channels of programmable, threephase power controllers. Long-duration programs can be operated at a sustained level of $5 \mathrm{MW}$. Peak power level is afproximately $20 \mathrm{MW}$ for 40 seconds, twice an hour.

Thermal input is produced with either high-power lamps or graphite-resistance heaters. The radiant spectrum produced by these heat sources is shifted towards the infrared as compared to the solar spectrum.

Test items up to $17 \mathrm{ft}$. high can be accommodated inside the facility; an outdoor test pad is also available. The facility is lccated in a remote test area with widely separated facilities; thus, adequate safety precautions can be made for testing hazardous systems such as high-pressure steam generators.

Test data acquisition and reduction is accomplished on a dedicated, computerized data system located in the test complex.

Additional services which are available in the complex are: (1) a closed-loop cooling water system with a 300,000-gallon storage tank, (2) a 4,200,000 Btwhir cooling tower, (3) a boiler capable of producing up to $50,000 \mathrm{lb} / \mathrm{hr}$ of steam at 175 psig, and (4) high-pressure, large-volume nitrogen, oxygon, and argon gas storage tanks.

Testing programs which could be handled include:

1. Evaluation of sections of full-scale items at rated heat flux levels.

2. Evaluation of scale models.

3. Evaluation of engineering design problems such as flow stability and thermal stress effects.

Figure 12 shows the location of the Fadiant Heat Facility (Eldg. 6530) and the remote facility control point (located in 
Bldg. 6540). relative to other facilities in sandia's Environmental Test Area III. Figures 13 and 14 show the floor plan and elevation of the test bay of the Radiant Heat Facility.

\section{POKEP CONTROI APFARATUS}

Control modules of the Radiant Heat Facility (RH-1) consist of eight channels of three-phase electrical pulsers designed to control alternating current pulses to electrical heaters. Electromechanical servo systems program and control each channel of the facility to effect temperature-time heating. heat flux contrcl as a function of time, and simulation of aerodynamic heating.

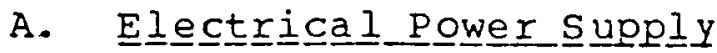

The Radiant Heat Facility (RH-1) is supplied by a 44,000-volt transmission line which is separate from the transmission line used by all other facilities in Area III. voltage to the ignitron controllers of the $\mathrm{RH}-1$ facility is reduced to $2400 / 4160$ grounded wye in a 5000-kVA transformer.

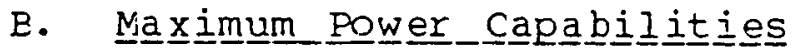

The maximum power output capability of the eight channels of the RH-1 facility is based on 95 percent of full-wave conduction of the ignitron tubes with a 2.4-kilovolt supply. The original specifications of the facility called for thermally rating the individual phase transformers to be suitable for one $t \in s t$ of 40 seccnds duration per hour to a maximum of 2.4 megawatts for each of the control channels, or a total of 19.2 megawatts for the eight control. channels. Several years of ocerating experience has proven the original rating to

be conservative. No apparent degradaticn of the transfcrmers has been observed as a result of two tests per hour at the specification thermal rating.

Higher current ratings are available in larger ignitron tubes which could increase the maximum power rating to 3.0 megawatts per channel; however, only one three-phase transformer bank is presently installed through which this power could be utilized.

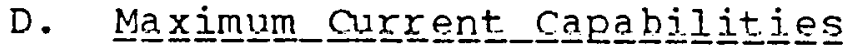

Maximum current capability of the RH-1 facility is based on 95 percent of full-wave conduction of the ignitron tubes and is ruled by a number of thermal and electrical characteristics inherent in the ignitron tubes. Table VIII is a tabulation of operating maximums of the eight control channels.

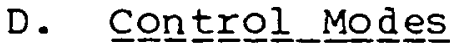

Four basic modes of programming and feedback control are available in the $\mathrm{RH}-1$ facility. These are: 


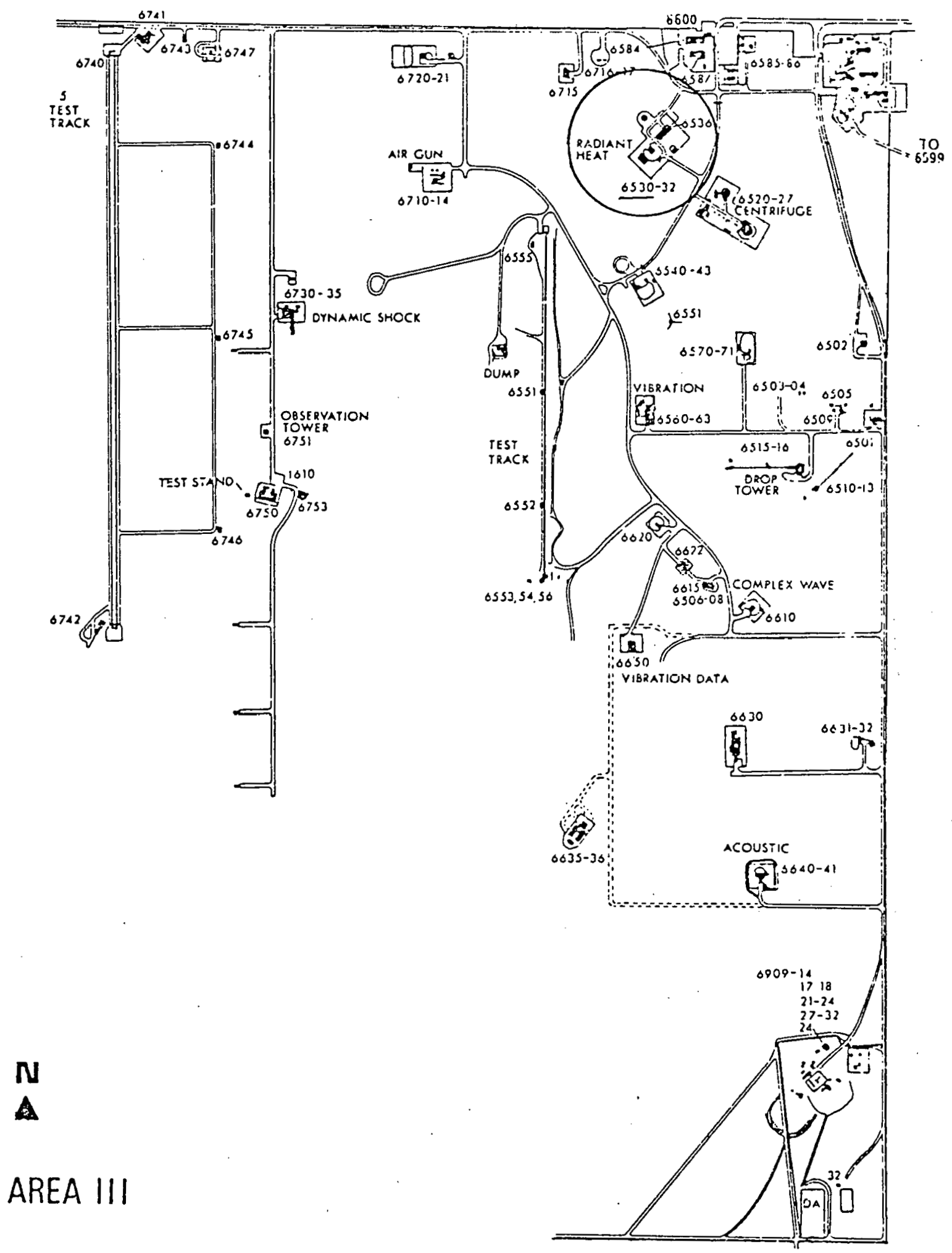

Figure 12. Location of Radiant heat Facility 


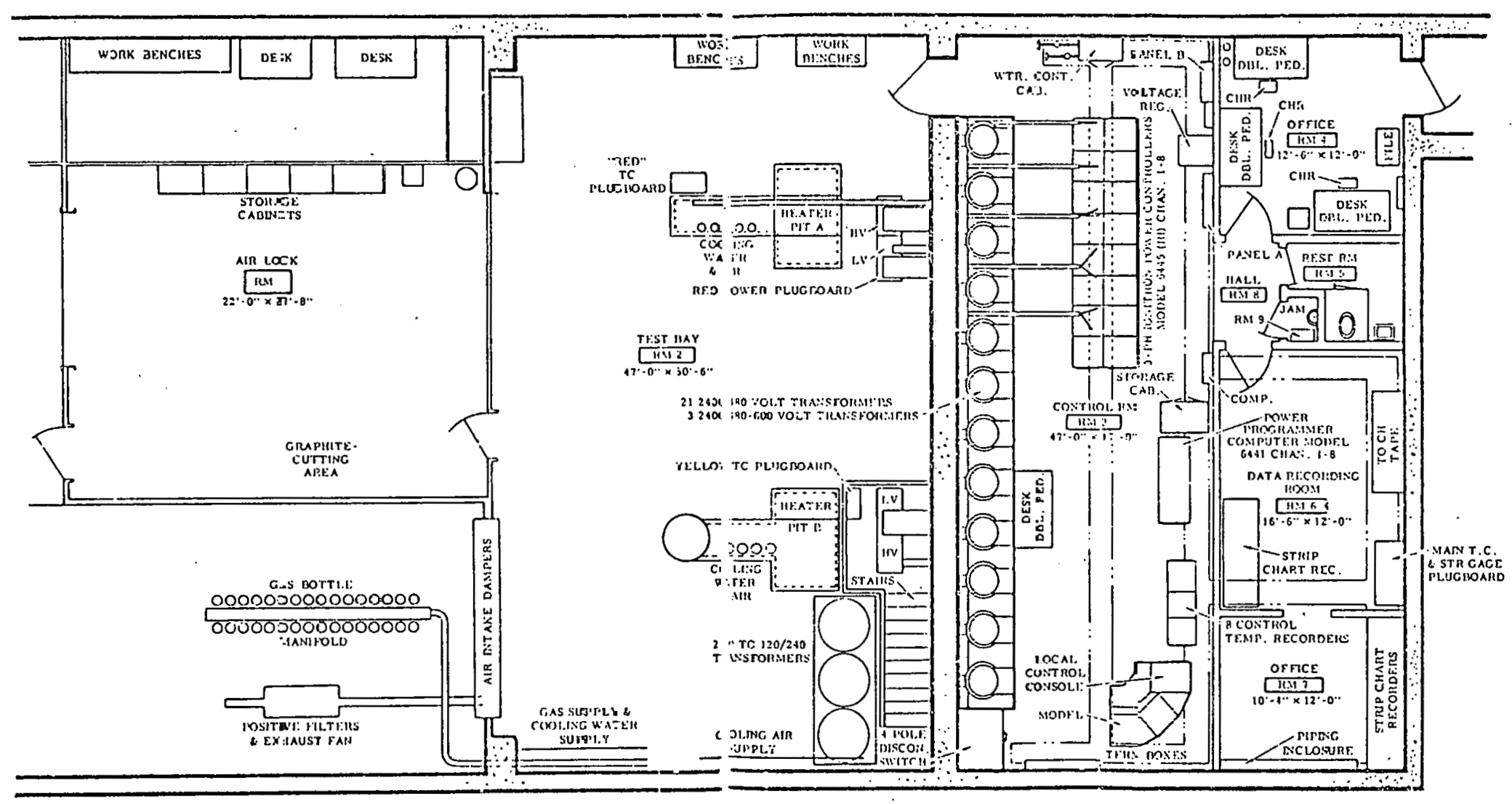

Figure 13. Floor Plan of Radiant Heat Facility 
1. Heat Flux as a function of time (QT)

a. by power feedback,

b. by heat rate sensor feedback, and

c. by optical pyrometer feedback.

2. Temperature-Time $(T-T)$

a. by thermocouple feedback, and

b. by optical pyrometer feedback.

3. Simulation of Aerodynamic Heating (EI) by

a. thermocouple and power feedback.

4. Constant Temperature (Soak)

a. by thermocouple feedback.

The methods of feedback most readily available and most commonly used are "power feedback" in the Heat Flux as a function of time (QT) mode; "thermocouple feedback" in the Temperature-Time ( $T-T)$ mode; and in the simulation of Aercdynamic (EI) mode, both "thermocouple" and "power" feedback are required.

Thermccouple feedback is required in the constant Tomporature (Soak) mnîa.

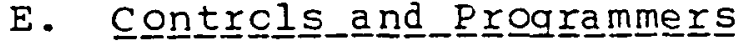

controlling and programming the facility may be done by either manual procedures or by automatic procedures. Each three-phase channel consists of one master phase and two slave phases; the two slave phases respond to the master phase by equalization of the load voltage. The channel Number 1 master phase can control subsequent channel master phases by the same load voltage equalization. Master-slave control is available in either manual or automatic operation.

The RH-1 program console consists of eight drums for programming $q$ (heat $f l u x$ ). TD (temperature), and $h$ (heat transfer coefficient) and two arums for programming Taw (adiabatic wall temperature). Drum rotation is accomplished by a DC positional servo-mechanism so that all drums rotate at the same rate, continuously variable from 10 to 3000 seconds for full rotation.

Automatic programming of $g, T D, h$, and $T a w$ command functions is accomplished by cutting the desired curve shape on aluminized graph paper and fitting the graph paper to an a epropriate program drum. The command functions are generated as voltage analogs from multiturn potentiometers, which are positioned by electrical servo-mechanisms driven by the curve followers. Skew rate (maximum probe follow rate) of the follower mechanism is approximately 5 inches per second; maximum travel from zero to full scale is 7 inches which makes the programmer faster in response than most commonly used heater loads. 


\begin{tabular}{|c|c|c|c|c|c|}
\hline$\underline{\text { Chan }} \underline{\underline{1}}$ & neㅌ﹎. №. & $\begin{array}{l}\operatorname{Max} \\
\text { FMS } \\
\underline{\text { Vol }} \underline{\underline{t}} \underline{\underline{S}}\end{array}$ & $\begin{array}{l}\text { Max. RMS } \\
\text { Current/ } \\
\text { Amps }\end{array}$ & $\begin{array}{c}\text { RMS } \\
3 \text { Sigma Power } \\
\text { JMegawatts }\end{array}$ & $\begin{array}{c}\text { Filectrical } \\
\text { Connections to } \\
\text { Heater_Load }\end{array}$ \\
\hline & 1 & 480 & 1660 & 2.4 & Open or closed delta \\
\hline & 2 & 480 & 1660 & 2.4 & Y \\
\hline & 3 & 480 & 1660 & 2.4 & Isolated phases \\
\hline & 4 & 480 & 1660 & 2.4 & open or closed delta \\
\hline & 5 & $\begin{aligned} 480 \varepsilon \\
600\end{aligned}$ & $\begin{array}{l}16008 \\
1340\end{array}$ & 2.4 & Upen or closed delta \\
\hline & 6 & 480 & $1 \in \epsilon 0$ & 2.4 & open or closed delta \\
\hline & 7 & 480 & 1660 & 2.4 & open or closed delta \\
\hline & 8 & 2400 & 400 (est.) & 3.0 & $\begin{array}{l}\text { Not controlled } \\
\text { through ignitron } \\
\text { tubes }\end{array}$ \\
\hline & 8 & 480 & 1660 & 2.4 & open or closed delta \\
\hline Any & channel & $\begin{array}{l}120 / \\
240\end{array}$ & $\begin{array}{l}\epsilon \in 00 / \\
3300\end{array}$ & 2.4 & $\begin{array}{l}\text { Y, delta or isolated } \\
\text { phases }\end{array}$ \\
\hline Any & channel & $\begin{array}{l}240 / \\
480\end{array}$ & $\begin{array}{l}1240 / \\
620\end{array}$ & 0.9 & $\begin{array}{l}\text { Y, delta or isolated } \\
\text { phases }\end{array}$ \\
\hline Any & channel & 480 & 1660 & 2.4 & $\begin{array}{l}\text { Y, delta or isolated } \\
\text { phases }\end{array}$ \\
\hline
\end{tabular}

NOTE: All channels may readily be reconnected to open or closed delta configuration.

\section{QUARTE IIJERARED LNMPS}

\section{A. Lamp Characteristics}

A large amount of the testing at the Radiant Heat Facility involves heat fluxes in the range from 10 to $200 \mathrm{Btu} / \mathrm{sq}$ ft-sec. These low-to-medium-level heat fluxes are normally provided by heater arrays equipped with $\mathrm{T}-3$ tubular quartz 
infrared lamps. The $T-3$ quartz lamp consists of a tungsten filament sealed in an inert gas-filled quartz tube $3 / 8$ inch in diameter. The normal sizes used are 10, 16, and 25 inch, which corresponds to the heated length of the filament. Also, 5 and 38-inch lamps are available for special uses.

\section{Heat_Concentratations}

The normal heat concentration of the quartz lamp is 100 watts per linear inch of heated filament. The 10- and 16inch lamps are available with heat concentrations of 200 watts $p \in r$ linear inch, while the 10-inch lamp is also available with a heat concentratisn of 360 watts per linear inch of heated filament. The 100-watt per inch lamps have either a clear or translucent quartz tube. The translucent tube is desirable when a small number of lamps are being used and an even heat distribution is needed to avoid hot spots. The high output lamps are available with clear quartz tubes only. The T-3 quartz lamp offers the highest heat concentration of any infrared source of this type.

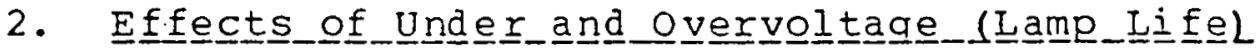

One of the features of the $T-3$ lamps is their ability to handle cvervoltages for short times. The normal lifo of the lamp is 5000 hours when operated at rated voltage, which is 240 volts for the 10 -inch lamp as ar example. When operated at 225 percent of rated voltage, the limp life drofs to 5 or 6 minutes at most; however, at this overvoltage, the power output of the lamp increases to more than trree times the rated power output. This allows the T-3 lamp to be used when very high peak heat fluxes with short duration are required which could not be obtained at the normal rated voltages. Figure 15 gives the power and color temperature output of a typical quartz lamp when operated above and below. normal rated voltages.

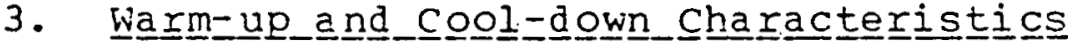

The $T-3$ quartz lamp has a small thermal mass, thus allowing very rapid heat-up and cool-down rates. When the rated voltage is applied to the lamp as a step increase, the output will reach 70 percent of the rated output in 2 to 3 seconds. The lamp will cool down to 20 percent of rated cutput in 2 to 3 . seconds after power is shut off.

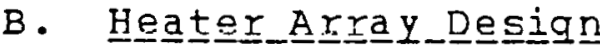

To take advantage of the features of the quartz infrared lamp, it is necessary to install it in a heater array which will direct the radiant energy from the lamp toward tho test item. The heater array then serves as a support for the lamps, by holding them in the desired arrangement, while 


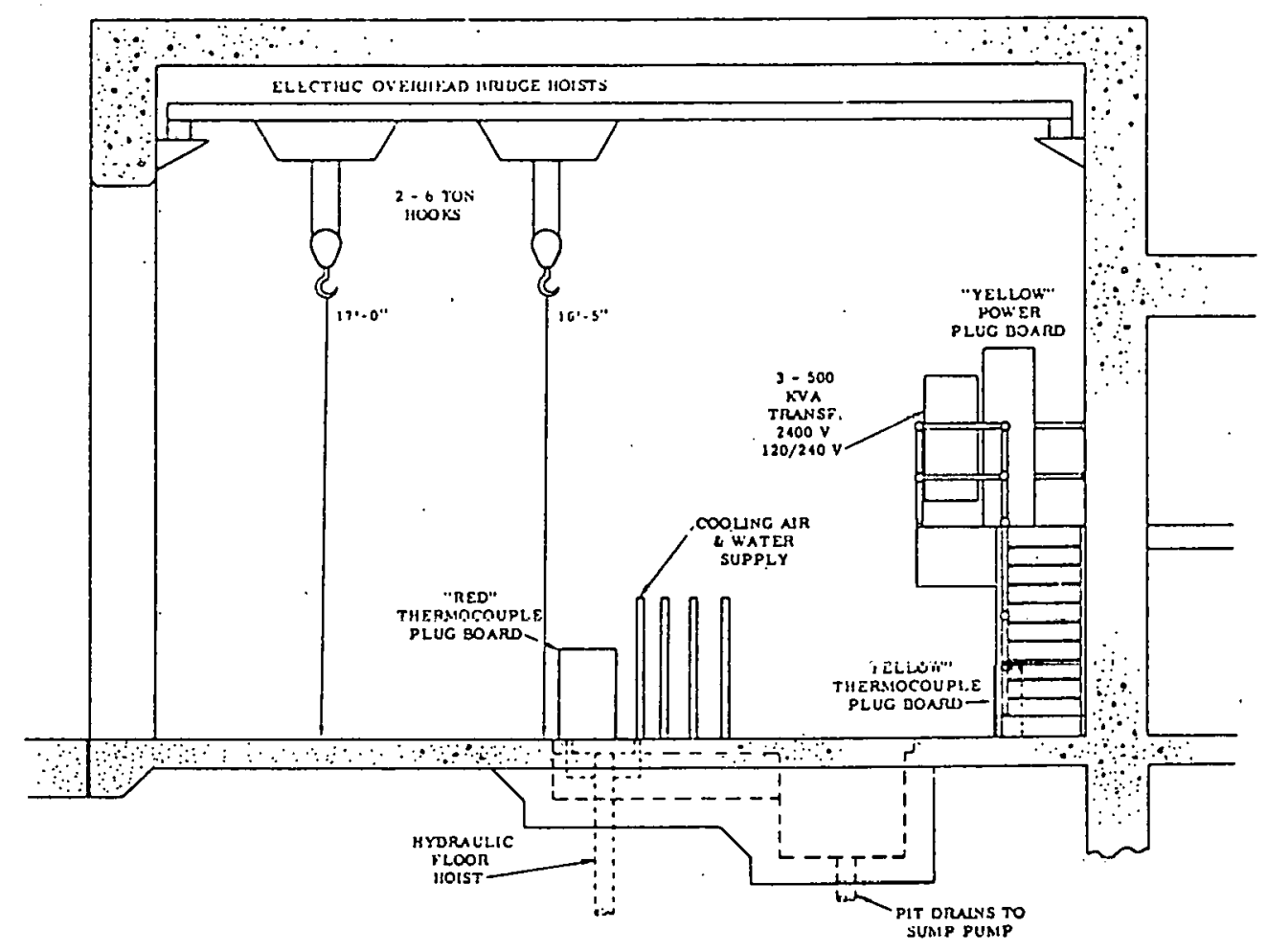

Figure 14. South Elevation of Test Bay

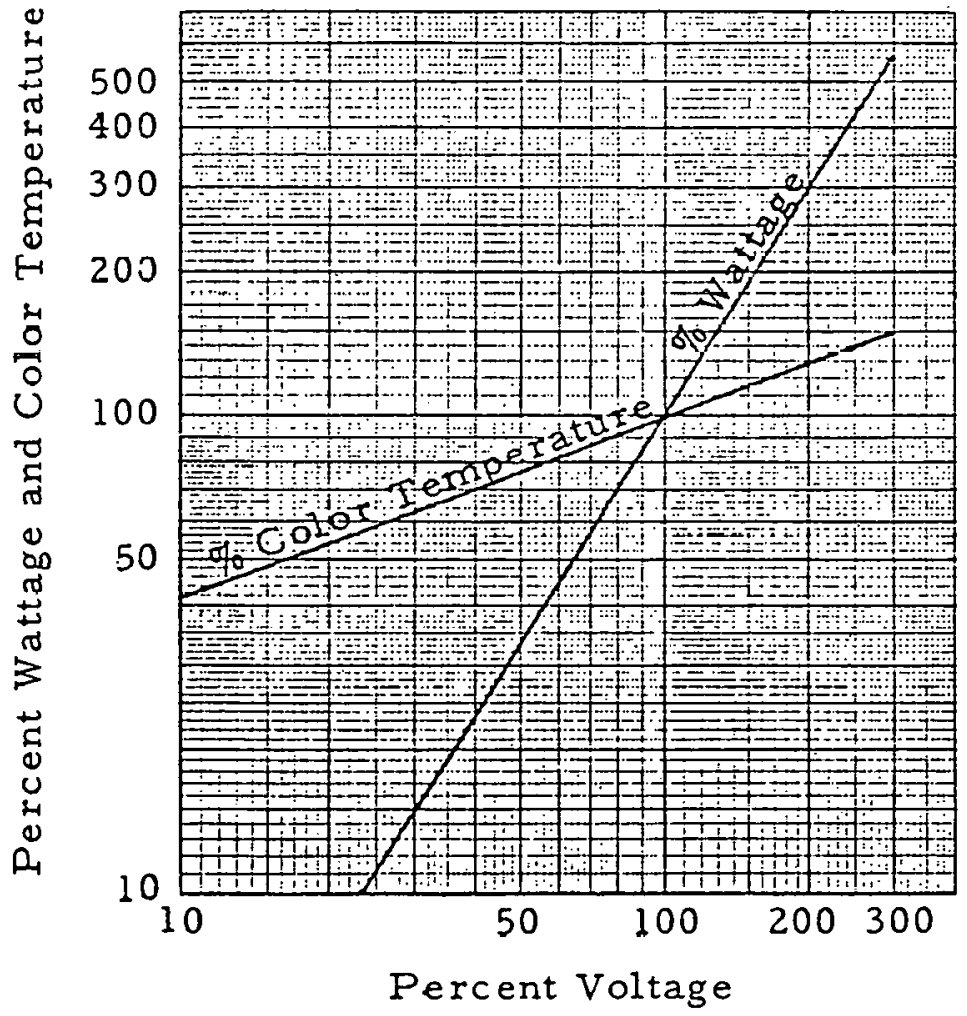

NOTE: Color Temperature $2500^{\circ} \mathrm{K}$. at $100 \%$ Voltage

Figure 15. Voltage characteristics of $T-3$ Quartz Iamps 
providing a reflector behind the lamps, which is normally aold plated. It is also necessary to provide cooling for the lamp seals and the quartz tube. The end seals are normaliy cocled by water cooling the lamp holders, although it is sometimes possible to merely air cool the seals when low level tests are required. The quartz tubes are cooled by blowing air over the tube surface either radially or axially as the design permits. In some tosts, where the higher heat fluxes are required, it becomes necessary to water cool the reflector in order to avoid destroying the heater array.

\section{GRAPHITE RESISTOR HEATING}

Graphite resistor heating is used to simulate such environments as launch pad abort fires or the thermal energy from nuclear bursts. It is also used for heat shield or other types of material studies.

Programmed pulses of. various shapes, flux levels, and pulse durations can be obtained using the automatic control equi pment.

The type of flat graphite resistor normally used is shown in Figure 16. The thickness of the resistor used is either 0.375 inch or 0.750 inch; however, the other dimensions are the same as shown.

One, two, or three resistors are used depending upon the size of the test specimen and the flux rate required. With the resistors run horizontally, support rods have to be used to prevent the resistor from sagging and closing the gafs, thereby shorting out sections. When the resistors are mounted vertically, no supports are necessary. Electrical arcing across the resistor slots is reduced by blowing inert gas across the graphites from a manifold.

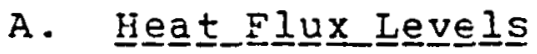

The incident flux levels obtainable will range from the maximum flux level obtainable from the quartz lamp up to aboct 420 Btu/sq $f t-s e c$ incident. The maximum level attainable on any test specimen depends upon the shape and size of the item and whether or not it can be mounted in a test fixture that has a high reflectivity.

Ali of the higher flux levels have been obtained. using a shutter in front of the test it $\mathrm{em}$ so that the graphite resistors can be brought up to temperature before the test item is exposed to the heat flux. Refrasil cloth is used to cover the shutter to help protect it from the high exposure temperatures.

\section{B. Pul $\underline{\text { se }}$ Characteristics}

\section{Pul se Types}




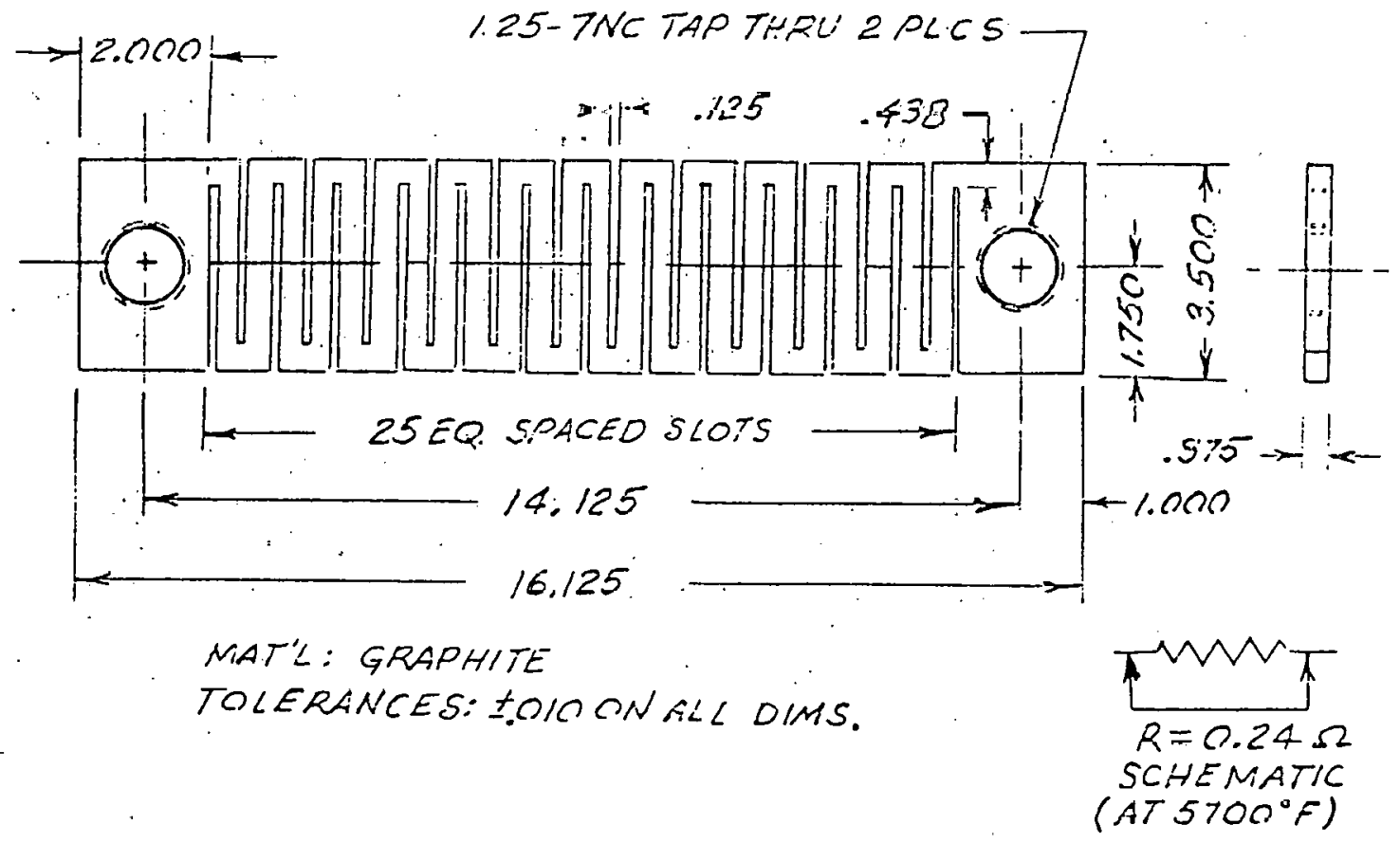

Figure 16. Straight Resistor 
There are three main parts of the heat pulse that can be varied. These are the rise and fall time with their associated shapes and the duration of time at the peak.

\section{2. $\underline{\text { Rise }}$}

There are several methods of controlling the ris: time of the heat flux pulse. One method is to use the natural rise in temperature of the graphite resistor which runs about 20 seconds for a temperature required to reach $350 \mathrm{Btu} / \mathrm{sq} \mathrm{ft}-\mathrm{sec}$. A slower rise time than the above method can be obtained by Frogramming power to the resistors at a slower rate. Another method is to use a shutter between the graphite resistors and the test item. The resistors are brought up to the required temperature, the shutter is opened, and the rise time is practically instantaneous.

\section{FaIㅣ Time}

The fall off due to the natural cooling of the graphite resistcrs to 20 percent of max flux occurs in a fproximately 10 seconds. The heat flux can be cut off near the end of the pulse by the use of the shutter which causes a sudden drop of the flux to zero. The heat flux can also be cut off at maximum heat flux by the use of a shutter.

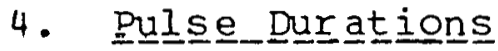

The pulse duration is dependent upon the peak power input level. In general, the higher the flux level, the shorter the pulse duration that can be obtained. A level of 350 Btwsq ft-sec can be maintained for approximately 30 seconds if a good reflective surface is used to hold the test specimen.

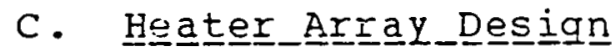

Most tests are run using the graphite resistor heater arrays with a water cooled and gold plated reflector behind the graphite resistors to reflect as much of the radiant energy as possible. Other arrays may be designed to follow the contour of various shapes. These would then be backed by a water-cooled, gold-plated reflector which would also support the electrcde rods screwed into the resistors. 

Facility," Edwards Air Force Base, Calif.

\section{Intro duction}

The NASA Hign TEmferature Loads Calibration Labcratory at the Flight Research Center, Edwards, California, has tho capability of testing structural components and complete vehicles under the combined effects of loads and temperatures, and calibrating and evaluating flight loads instrumentation under conditions expected in flight. The laboratory provides close support of flight-to-flight program planning by structuralintegrity testing, instrumentation calibrations, ana analysis of unexpected problems encountered in the course of exploratory flights.

\section{Gener $\underline{\text { al }}$ DES $\underline{\text { cription }}$}

The laburatury is a liandyr-type structure with a small shop and office area attached to one end to accommodate the operations staff. It is located adjacent to Rogers Dry lake and is connected to the dry lake and the Edwards Air force Base runways by a ramp and taxiway.

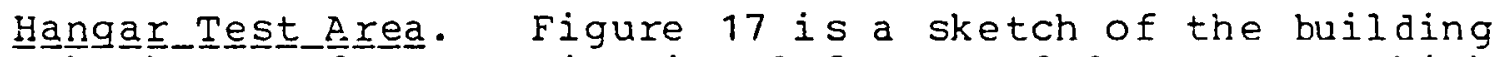
layout. The hangar-door opening is 40 feet $(12.2$ meters) high and 136 feet (41. 6 meters) wide. Additional access to the test area from the exterior is provided by personnel dcors and an equipment door. Access to the test area from the shop area is provided by two equipment doors. The unobstructed test area is 150 feet ( 45.7 meters) long by 120 feet ( 36.6 meters) wide by 40 feet (12.1 meters) high. There are 16 tiedown slots spaced $t$ feet ( 1.8 meters) apart. 7 instrument wire trenches, 7 electrical power trenches, and 5 mechanical trenches.

The cross-sectional dimensions of inches (25.4 centimeters) by 12 inches (30.5 rechanical trenches distribute hydraulic the trenches are 10 centimeters). The power, water, and compressed air to the test area. The maximum load capability of the tiedown slcts is 15,000 pounds ( $\epsilon 7,000$ newtons) uplift $\in v e r y$ 2 feet $(0.6$ meter). Figure 18 shows a sketch of a typical tiedown slot. A 5-ton (44,000-newton) overhead crane services the entire hangar test area. 
Control rocom.

The

control

room

for the heatina equipment, loading equipment, and data-acquisition system is on the second floor. Two observation windows, 11 feet ( 3.4 meters) wide by 4 feet (1.2 meters) high, and a closed-circuit television system are provided for monitoring the test area. The telovision system has several cameras which can be positioned in tho haraar test area; one can be controlled remotely from the control room for tilt, fan, elevation, focus, and zoom. A two-channel intercommunication system is provided between the control room and the twelve acquisition sites of the data-acquisition system in the hangar test area. Audio and video tape machines provide voice communication and visual recording of the test.

Power Distribution. Twenty megawatts of 480-volt, threephase, 60-cycle power are available for distribution to 512 solid state SCR, or 2.3 megawatts to 24 ignitron power requlators. Hydraulic power consists of a 4.5 gallon per minute 1284 cubic centimeter fer second) supply operated at 3000 pounds per square inch (20.7 meganewtons per square meter). compressed air is supplied by a 125-hcrsepower (93,250-watt) compressor capable of delivering 845 cubic feet per minute $(0.398$ cubic meter per second) at 60 pounds per square inch $(413.7$ kilonewtons per square meter).

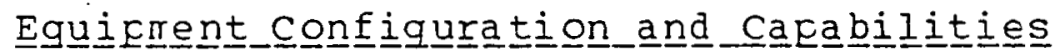

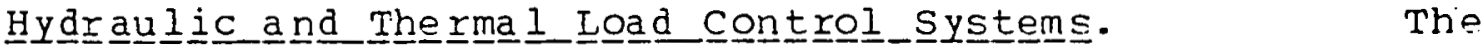
hydraulic and thermal load control systems have the capability of loading and heating test specimens simultaneously by fcllowing programs of load and temperature. The hydraulic and thermal load control systems are programmed by the same type of function generator and by similar controllers. Both the function generators and the hydraulic and thermal load contrcllers are digital devices.

Two manually operated air-hydraulic pumes are also available for manual loading of structures with hydraulic jacks. The capacity of each jack is approximately 8.000 pounds (35. $\epsilon$ kilonewtons).

Therma I_Lcading system. The available programmed heating equipment consists of: (1) a 512 channel direct digital control system employing solid stat $E S C R$ pow $E$ regulators capable of a total of 20 megawatts available for a single test, or (2) 24 analog channels using ignitron power regulators, each with a Fower capacity of 100 kilowatts. Electrical power is connected to the power control channels from the transformers with bus bars. Connecticn of electrical power to the lamps is by flexible cable with high-temperature insulation. Cables to the lamps are routed through floor trenches.

The primary protective or fail-safe capability used with the heating equikment is a voltage-limiting system which enables the operator to limit the voltage applied to the heat lamps for each channel control. To use this system effectively it is necessary to know the amount of power needed to achieve the 
heating rates and temperature levels required by the tests. Once this information is know, it is necessary ts limit the powr applied to each channel to avoid exceeding these values.

Heat is applied to the specimen through the use of infrared quartz lamps which are available in various lengths from a 5-inch (12.7-centimeter) lighted length to a 32-inch (81.3centimeter) lighted length. Feflector arrangements are readily adaptable to individual requirements for heating rates in the range of 0 to $i 00 \mathrm{Btu} / \mathrm{sq} \mathrm{ft}-\mathrm{sec}(1.13 \mathrm{Mh} / \mathrm{sq} \mathrm{m})$ and temperatures uf to 3000 degrees $F(1922$ degrees $K)$.

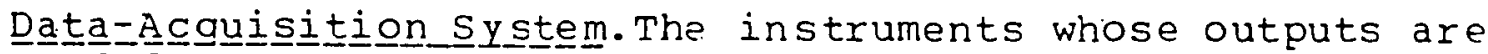
to be recorded are connected to acquisition "sites" near the test setup. Each acquisition site can accommodate up to 100 channels of any instrumentation mix. Twelve acquisition sites are available, so that the system can handle up to twelve hundred channels, The sites contain signal conditioning and strain-gagebridge balancing equipment. They also convert data from analog to digital form for transmission to the control room. This configuration minimizes effects of electrical noise generated by the thermal loading system. Each site has its own airconditioning unit to improve the reliability of its performance in the changing thermal environment.

The data acquired by the acqui sition sites are routed to the control console, which is the interface between the tost conductor and the data-acquisieion system. The console contains a number of displays which keep the test conductor informed about the progress cf the test. The control console, in turn, communicates with a high-speed digital computer which acts as a command and ccntrol device for the data-acquisition system. Under stored program control, it commands the channel sampling sequence and the sensitivity at which each channel is measured. Data are formatted in the computer for output magnetic-tape units. Information is recorded on magnetic tape in IBM 3609 track format. Data are reduced on the NASA Flight Research center system 360 general-purpose computer.

Numeric disflays of test time and data from any one channel (reduced to engineering units if desirea) and a bar graph displaying analog lines whose lengths are proportional to data from any 32 selected channels ar $\epsilon$ available at the control console. Also, three strip-chart recorders are connected to tho control console to provide quick-look analog time histories of up to 24 channels cf information. If desired, an $X-Y$ plotter can be connected to two strip-chart channels to produce, in real time, a plot of one variable versus a nother. Twenty alarm lights are available to indicate noteworthy or hazardous conditions. The lights can also be used for a utomatic test shutdown. To observe the test, the test conductor sits in front of a large window overlooking the test area. For more detailed, close-up viewing. closed-circuit television is provided. The control room, which is remote from the test area, can be connected by an intercommunication system to any acquisition site. 
Instrumentation. The transducers available for use in the facility include strain gages, thermocouples, load colls, and position-transducers.

A strain-gage laboratory within the facility provides th. capability for installing and testing strain gages under environmental conditions of heat and load. Various types of strain gages, including those requiring welded and flame-spray attachments, can be installed. Thermocouples can also be installed in the strain-gage laboratory. The thermocouples used are typically spot-welded chromel-alumel.

Forty-eight potentiometric displacement transducers are available with the following specifications:

\begin{tabular}{|c|c|c|c|c|c|c|c|c|c|}
\hline & & $R$ & & & Ressol & i으므 & Cable 1 e & nㅗ호으 & Quantity \\
\hline & & $i \underline{n}=-$ & & ćm & in & $-\underline{\mathrm{mm}}$ & 으므. & $-N_{-}$ & \\
\hline & to & 1 & 0 & 2.54 & \pm .002 & 0.05 & 9 & 2.5 & 4 \\
\hline & to & 6 & 0 & to 15.24 & \pm .011 & .28 & 9 & 2.5 & 14 \\
\hline & to & 12 & 0 & to 30.48 & \pm .022 & .56 & 9 & 2.5 & 12 \\
\hline 0 & to & $12(a)$ & 0 & to 30.48 & \pm .017 & .43 & 19 & 5.3 & 4 \\
\hline 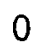 & to & 24 & 0 & to 60.96 & \pm .042 & 1.07 & 14 & $3: 9$ & 14 \\
\hline
\end{tabular}

(a) This transducer has a sefarable cable which permits the cable to release when its $r$ ange is exceeded without damage to the comfonent parts.

Twenty-four dial-gage displacement-measuring devices are also available with ranges varying from $3 / 8$ inch $(0.95$ centimeter) to 4 inches $(10.16$ centimeters). 


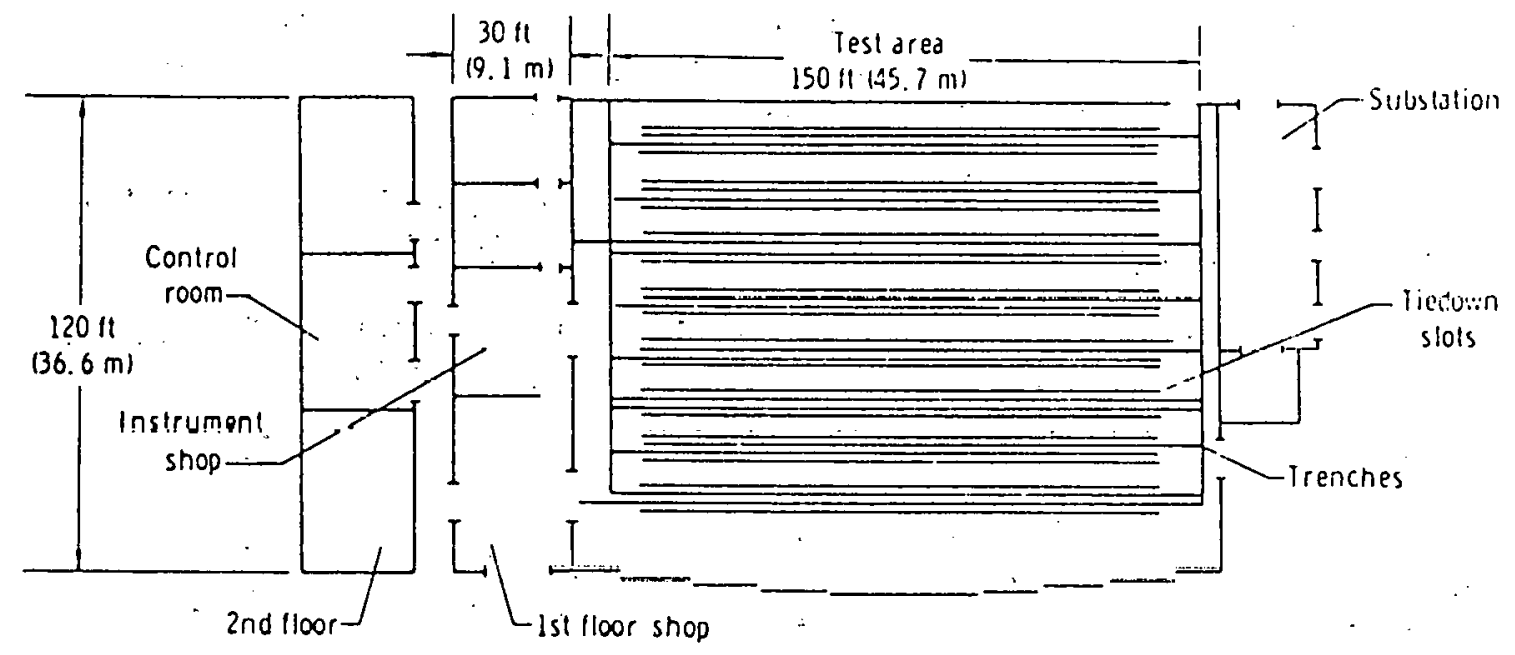

Figure 17. Building Layout of IJASA High Temperature Loads Calibration Laboratory

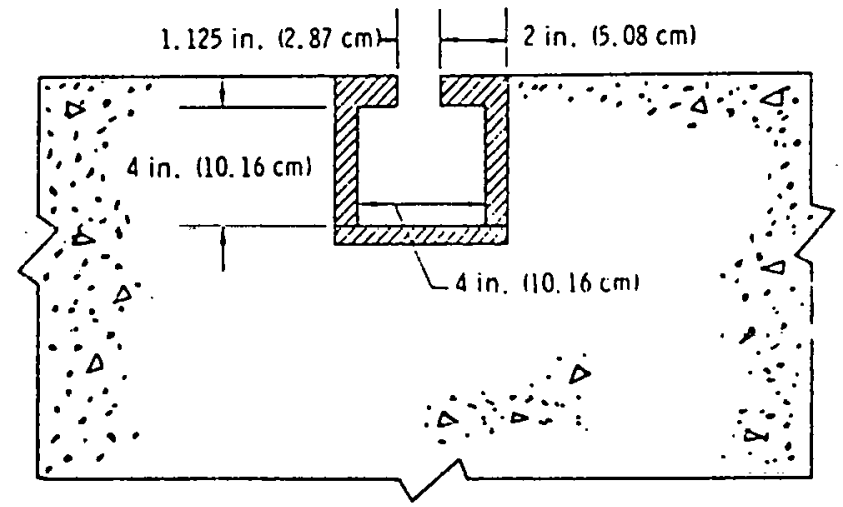

Figure 18. Cross Section of mypical Tiedown slot 


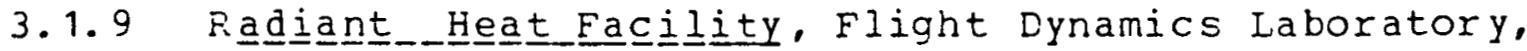
Wright-Patterson Air Force Base, Daytor, Ohio.

The figh Flux, High Temperature facility is in the. Structures Laboratory. Employing quartz lamps and graphite radiant heaters, this facility is capable of flux levels in excess of $100 \mathrm{~W} / \mathrm{sg} \mathrm{cm}$ with a continuous input power of 23 MWe and over 50 MWe for a five minute period. A great deal of nuclear pulse simulation work is being conducted on test panels of up to $\epsilon$ ft by 6 ft. Grid flux control fiexibility can be achieved. Nearly 2,000 data channels are available as is instrumentation. This laboratory is manfower limited for the next year and currently fully scheduled with tests. Availability beyond that time is not certain.

The need for conducting structural test programs at elevated temperature has resulted in the facility as it stands today. $50,000 \mathrm{KW}$ of controlled electrical power is available with the necessary heat controls and switchgear to conduct tests up to 3000 degrees $F$. As an integral part of the facility. a large high speed data acquisition and processing system was included as well as erogrammed loading systems.

A large liguid nitrogen facility, including a 10,000 gallon Dewar, cryogenic pumping, piping test basin, and barrier, is available within the structures Test Facility.

Heating System. Fith 23,000 KVA continous power and a peak powe $r$ of 50,000 KVA available for testing, the $A i r$ Force Flight Dynamics Laboratory structural rest Facility has the capability of testing many large structures while simulating their true thermal environment.

In order to control this large amount of power, two systems are available; the 580 KVA and the $25 / 60$ KVA system. The larger system has 80 channels of $580 \mathrm{KVA}$ each. The contrcllers for this system make. uf what is referred to as the Heat control computer system. The Heat control computer is a magnetic drum, electronic storage computer for calculating the amount of power required to simulate aerodynamic heating or cooling of a given test specimen and to control the flow of electrical energy in accordance with these calculations. The equipment is capable of generating 170 simultaneous functions (time versus other selected parameters) ard six time bases.

The analcg portion of the equipment is capable of controlling test temceratures to 7500 degrees $F$. Function generators are provided for linearization of standard thermocouples and power measuring devices.

The $25 / 60$ KVA system provides 210 - 60 KVA controliers and 550 - 25 KVA controllers. These controllers function in the time versus temferature or preset fower level modes only. Frogram inputs to the controllers are analog signals which come from external function generators. 
Temperatures may be programmed as Heat Flux Density ( $(R)$ or Time Temperature, both on real-time basis. This controlled electrical power feeds special radiant-heat lamps in custom designed reflector assemblies to achieve the thermal simulation. Range of temperature simulation is 150 degrees $F$ to 3000 degrees $F$ on large surface areas, with heat fluxes of $110 \mathrm{Etu} / \mathrm{sq} \mathrm{ft} / \mathrm{sec}$.

Datta﹎. A cguisisition a Acquisition system provides a complete instrumentation capability in support of the structural integrity testing performed on advanced aerospace vehicles. The measurements performed by this system fall into two basic categories: indications of structural response, and environmental control system feedback sensing.

The heart of the instrumentation is the Data Acquisition and Processing system (LAPS) which has 1928 data channels. This system is a time-shared commutated system, with maximum sampling rates of 100 samples per channel per second. All data are ccnverted into digita 1 torm and are both recorded on magnetic tape and entered on-line into a CDC-16048 computer which produces a real-time test data display. Recorded data can be processed later (off-line) by the same computer. The system's hard copy output is both tabular and graphical, on pafer, and/or on microfilm. The real-time continuous monitoring of structural response by advanced computing equipment results in a failureprediction and prevention capability that frecludes catastrophic failure.

The electrical outputs from these transducers are recorded by a variety of instruments, depending on the nature of the particular test. The primary data acquisition device utilized for the majority of tests is the High speed Digital Data Handing system.

It is this rapid response capability which allows meaningful application of limit-alarming and failure indication methods. Failure prediction, together with computer control of test input parameters can form the basis of a completely automated test program. The sensors most utilized in this work are capable of reasuring force, elongation, acceleration, flow, pressure, thermal heat flux, cryogenic and elevated temperature, and unit elongation (strain) over a broad temperature range.

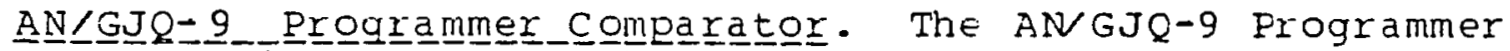
Comparator $(Q-9)$ is a central checkout system that automatically coordinates the activities of several systems in the structures Test Facility.

The $Q-9$ can energize equipment, check its condition, put it into operation, and shut it down. The $Q-9$ also has the capability of recording the performance of a piece of equipment as well as any malfunctions that occur during the process. In the event of a malfunction that cannot be rectified, the Q-9 can be made to substitute alternate equipment and continue the overall plan. 
Since the Q-9 can sense 2000 test points and Ferform another 2000 operations, it is extremely useful in conducting large and complex test proorams where electrical, electronic, bydraulic, pneumatic, and cryogenic systems are involved, thus saving a tremendous amount of manpower and time.

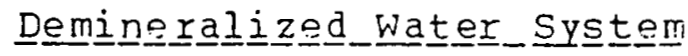

De $\underline{s} \underline{\underline{r}} \underline{\underline{i}} \mathrm{t} \underline{\mathrm{i}} \mathrm{cn}$. The demineralized water system is made up of the kadiant cooling water circulating system, the. P. F. cooling water Circulating system, and the Water Demineralizing flant.

a. Radiant cooling water Circuliting system Maximum water temperature in

system . . . . . . . . 113 degrees F Water circulated...... 600 G.F.M. Volume of water in system. . . 2000 Galions Rate of heat removal .... 4,440,000 Etu/hr

b. R. F. Cooling water circulating system Maximum water temperature in

system ......... . 120 degrees F water circulated . . . . . . 3440 G.P.M. Volume of water in system . . 5600 Gallons Rate of heat $r \in m o v a l . . . .10,000,000 \mathrm{Btu} / \mathrm{hr}$

c. The demineralizing plant is a two bed system consisting of a sand filter, cation unit, vacuum de-aerator, and a strong base anion exchanger. It is designed for continuous operation at 40 GFM and processes 19,200 gallons of raw water betiveen regenerations. 


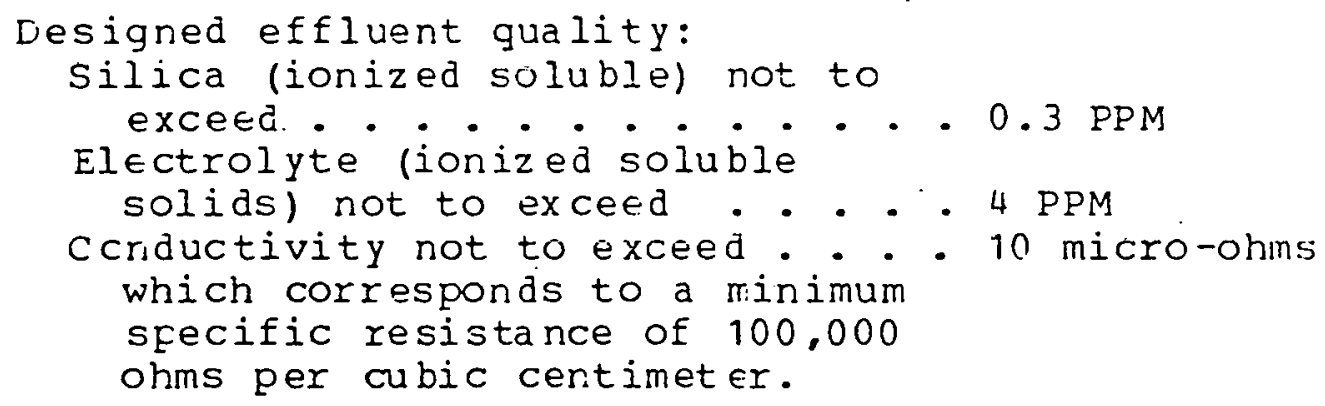

\section{므므모으르.}

(a) The radiant cooling water circulating systein provides $1 \mathrm{cw}$ conductivity water to the 80 ignitron power contrcliers in the elevated temperature test facility.

(b) The RF cooling water circulating system is used almost entirely for reflector cooling in support of elevated temperature test programs. lhe one exceutiun being the ringin induction heating loop on the $4 \mathrm{tl}$ floor.

(c) The water demineralizing plant is used to maintain water quality in the two circulating systems. 


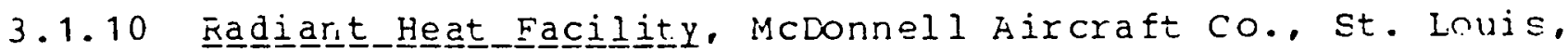
Missouri.

During the past decade, the space simulation and systems laboratories of the licDonnell Aircraft company has built uf a substantial cafability in tre area of high flux and high temperature radiant heaters.

Beginning with quartz lamp banks this capability has grown. with the inception of graphite radiant heaters, such that cold wall heat fluxes approaching $500 \mathrm{Btu} / \mathrm{sq}$ ft-sec and temperatures approaching 5000 degrees $F$ are achieved with test article areas ranging up to 32 square feet.

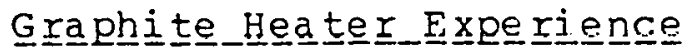

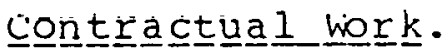

"Design and Fabricate a Graphite Radiant Heater capable of Delivering 100 Etu/sq ft-sec over a 16.5 x 26-inch Area" (Contract No. NAS1-8387). The heater assembly was used by INSAS-IRC for evaluation of hydrogen-cooled panels under simulated hypersonic flight heating conditions.

"Design, Development, Fabricaticn, and Testing of a High Heat Flux Radiant Grafhite Heater system" (Ccntract No. NAS1-8921). The goal of this effort was to develop a radiant heater capable of delivering $250 \mathrm{Btu} / \mathrm{sq}$ ft-sec to a four square foot cooled specimen in a pressure environment between atmospheric and $250 \mathrm{psig.} \mathrm{Figure} 19$ shows the $26 \times 26$-inch graphite radiant heater that was delivered to NASA-LRC at the conclusion of the effort.

"Graphite Radiant Heater Modules" (Contract No. F33(615)-69-C-0074). This contract, with the AFFDI-WPAFE, was to design and fabricate six graphite radiant heater modules to ufgrade the AFFDI heat flux cafability. These modules were ncminally 4 × 12 inches and operated from conventional ignitron power supplies.

"Design and Eabrication of a High Temperature Heating Array" (Contract No. NAS9-13091). A 26 x 30-inch graphite radiant heater was delivered to the structures Test section of NASA-JSC for use in testing space shuttle TPS.

"Design and Fabrication of a High Temperature Leading Edge Heating Array" (Phase I, Contract No. NAS9-13091; Fhase Ia, contract No. NAS9-13544). The requirement of this contract was to develop a graphite radiant heate $x$ array capable of heating a 60-inch section of full-scale shuttle leading edge to 3500 degrees $F$ in a Fressure environment ranging from atmospheric down to 0.5 torx. A $36 \times 5$ inch prototype heater was fabricated and used to evaluate design concepts and performance predictions. Presented in Figure 20 is a pictorial view of the 72-inch ccllapsible heater module whose detail design was completed as a part of this contract. This heater, in the 72-inch configuration, is used in the leading edge heating array while in 
tre 48-inch ccnfiguration (center section removed and shorter heater elements installed) it is used in the $48 \times 96$-inch flat heating array shown in Figure 21.

In_

An early graphite radiant heater was used in a company funded regeneratively-cooled engine inlet study. This heater was capable of delivering $120 \mathrm{Btu} / \mathrm{sq}$ ft-sec over a $4.5 \times 72-i n c h$ a rea.

A cylindrical, three-phase graphite heater system was designed and fabricated for testing the microwave properties of antenna windows during simulated entry heating conditions. This heater was capable of applying over 500 Btu/sq ft-sec to the antenna window located at the bottom of the cylinder while simultaneously allowing the passage of microwaves up through the hollow center.

A fcrerunner of the Shuttle TPS Heating Array built for NASA-JSC, was fabricated for use in the MDC Iaboratory for Snuttle TPS investigations. This heater, covered with a coated columbium reradiating susceftor plate to allow the specimen to be exposed to an oxidizing atmosphere while the heater oferates in an inert envircnment, is capable of heating a $24 \times 24$-inch insulating panel to 2500 degrees $F$. OVEr 1000 thermal cycle tests have been successfully run with this apparatus.

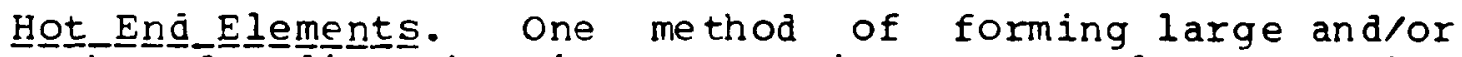
irregular shaped radiant heating arrays is ts use a large number of small heater modules stacked end-to-end and side-to-side. Advantages of this scrt of arrangement are: (1) utilization of "standard" heater units. (2) the possibility of infinite expansion to any size array, and (3) a large number of individual control zones for applying a spatial beat flux profile. One of the problems in a multi-modular array is the spatial uniformity of the delivered heat flux. across the inevitable gaps that exist between the modules. Side-to-side stacking presents no uniformity problem because the inter-modular gap can be made the same as the inter-strip gap. However, the problem becomes severe in the end-to-end configuration because of the necessity of froviding thickened ends on each strip for electrical connection and current turnaround. These thickened ends run substantially cooler than the active area of the heater strif so that when the are co-planar with the strips, a wide "cold stripe" is formed between the ends of adjacent heaters. This croblem was solved at the MDC Laboratcry by the invertion of the unique hot end element. (U.S. Patent No. 3.573.429). The hot end element has the thickened ends of each strip "tucked under" the strip. thereby allowing the active heating portion of the strip to extend all tre way to the end. These elements were originally installed on the $4 \times 12$ inch modules, but recent investigations have shown their feasibility in lengths up to at least 36 inches. An experimental 36 inch hot end element was successfully operated in the previously described Leading Edge frototype heater. 


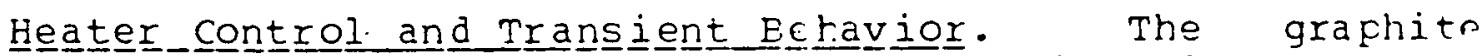
radiant heaters that have been designea and built in the MDC Laboratory have been operated at voltages varying from 14 to 480 volts, depending upon the application. This power is supfied, with or without a step-down transformer, from standard ignitron power controllers in various size ranging all the way uf to the largest available ("E" size, 2000 amf at 480 volts). For most development work it is sufficiert and desirable to manually control the ignitrcn, but for a number of tests controlled power was supplied to the heater by means of either set-point control or feedback control utilizing both thermocouple and heat flux sensor outputs as the feedback signal.

The transient behavior of a graphite heater is much like any other type cf heater inasmuch as the response is largely dependent upon the test specimen being heated. This is particularly true in the cooling case when a hot insulating test article will re-radiate energy to the heater elements causing a relatively slow cooldcwn, whereas with an actively cooled specimen the cooling rate of the heater assembly is sfectacularly rapid. Since graphite has no undesirable thermal stock properties, full power can be applied to a heater instantaneously with a typical response like that shown in Figure 22.

Heat Exchanger

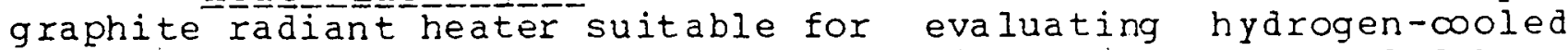
panels required the design and fabrication of a water-cooled heat exchanger to simulate the test article. The design criteria for this heat exchanger included absorption of 250 Btu/sq ft-sec without local vacorization which could cause total failure from the tube burnout. The design selected consisted of a bank of 0.25 -inch diameter $x .030$ inch wall copper tubes arranged one immediitely next to the other to form a solid wall of tubes not unlike the "water walls" often seen in high performance steam boilers. This heat exchanger is composed of eight secticns of thirteen tubes $\in a c h$ and $i s$ connected so that the water flow is down one section and back on an alternate section. This arrangement is able to generate a large heat transfer film coefficient with a modest pressure drop and relatively low flow rates all of which contributes to the efficient use of the water available. 


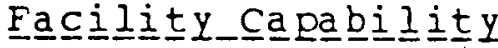

\section{Pow $\underline{\text { eq }}$.}

Total available steady state electrical power $7.5 \mathrm{MW}$. Peak transient power $34.5 \mathrm{~N} W$ for 60 sec (time determined by transformer temperature, less than 90 degrees $\mathrm{Cl}$. Thermal fower deliverable to test article $4.5 \mathrm{NW}$. Power contrsliers

3 channels of "E" Ignitron (2000 amp, 480 volts each) 54 channels of "P" Ignitron (200 amp, 480 volts each)

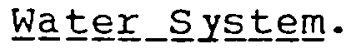

$300 \mathrm{gpm}$ at $80 \mathrm{psi}$

120 gen: at 1000 fsi

\section{Dața﹎.}

400 channel Central Data Acquisition System.

100 channel Dymec digital magnetic tape system.

50 channel mini-data digital magnetic tape system.

Quick-10ck printers.

Computer processing for overnight availability of graphical or tabular data in engineering units.

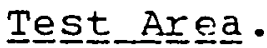

Indoor 50-ft high bay area.

Structural test jig with reinforced floor.

High fressure test cell, 50-ft high bay. 
Figure 19. Graphite Radiant Heater

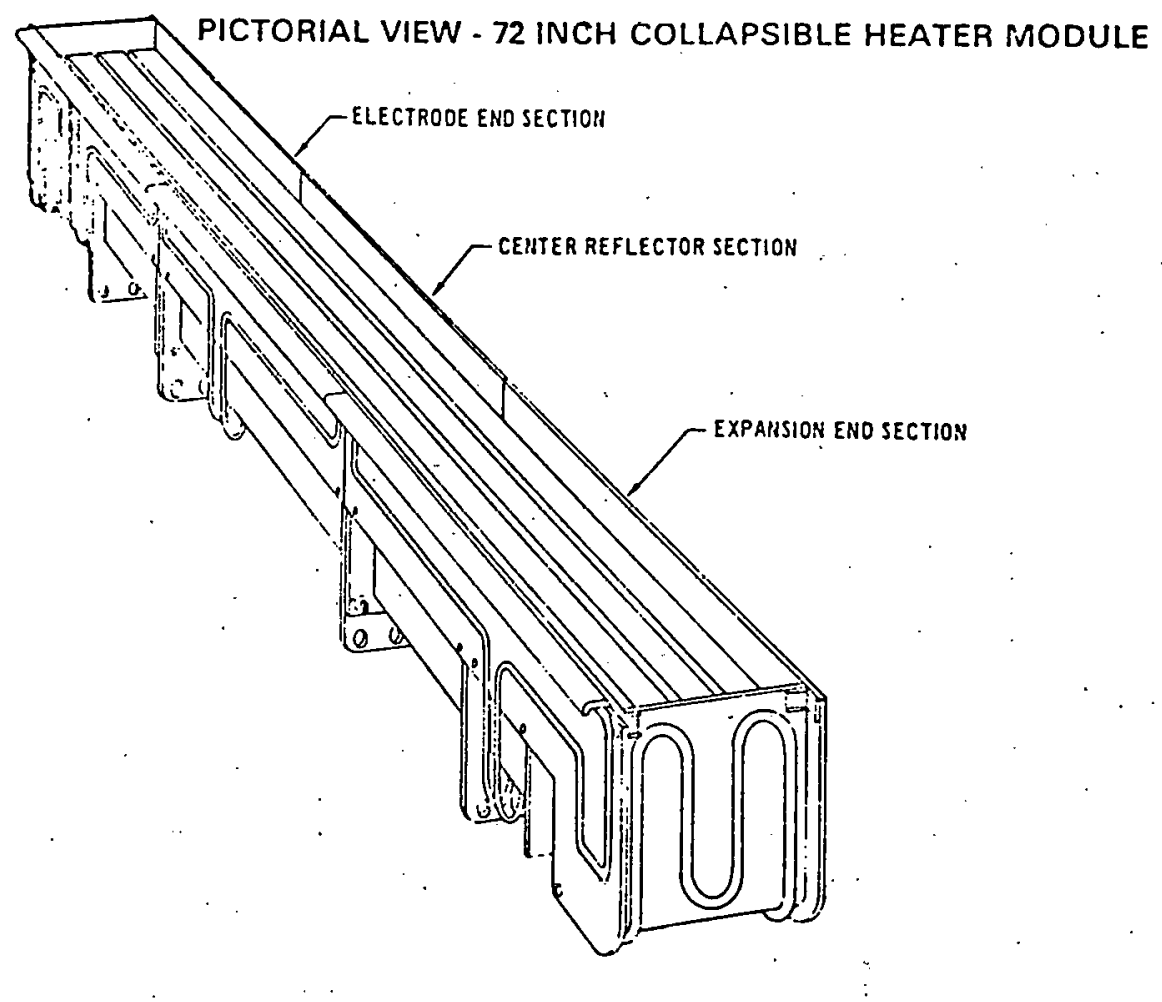

Figure 20. Heater Module 


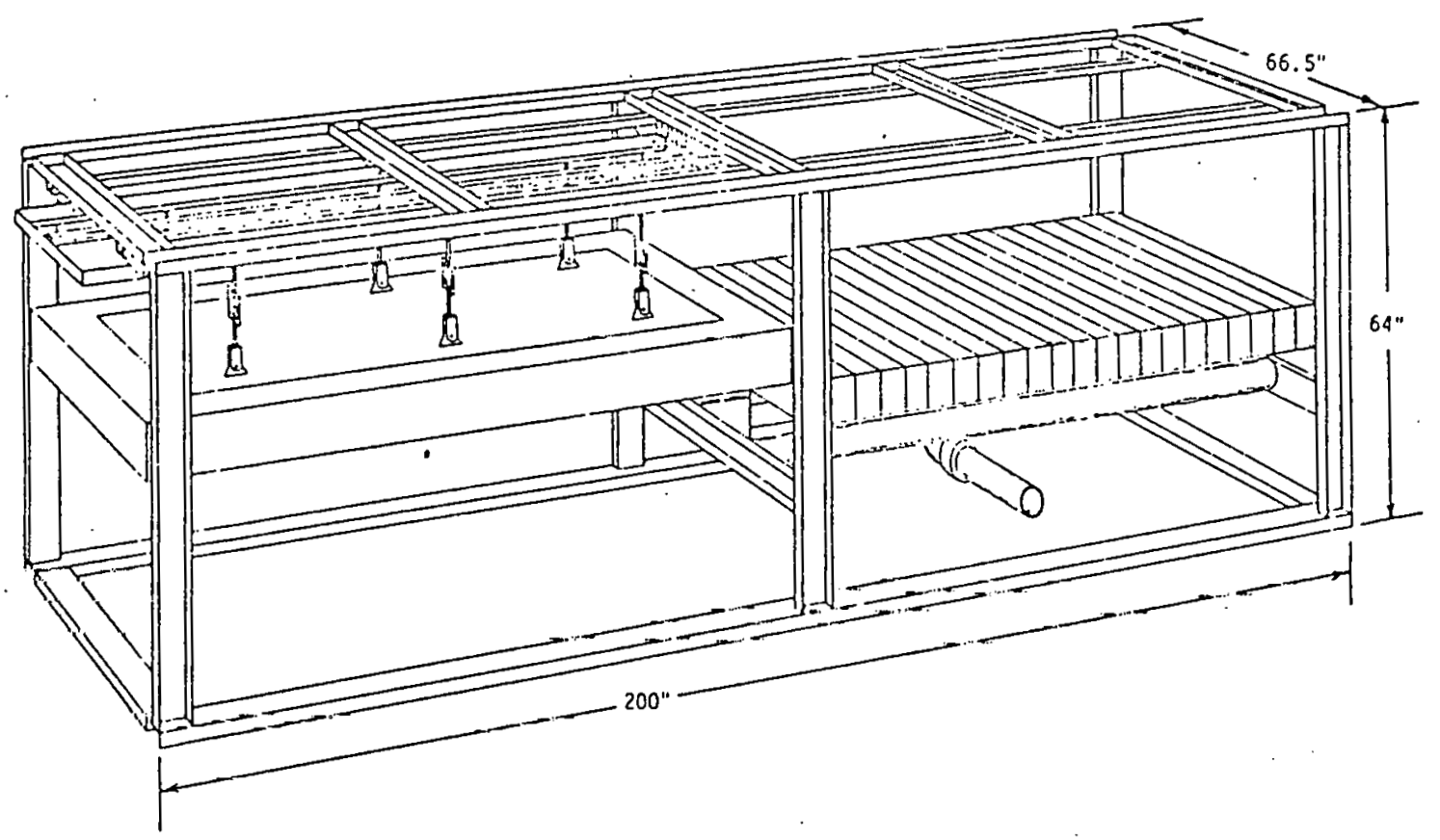

Figure 21. Flat Heater Array

\section{Transient Test}
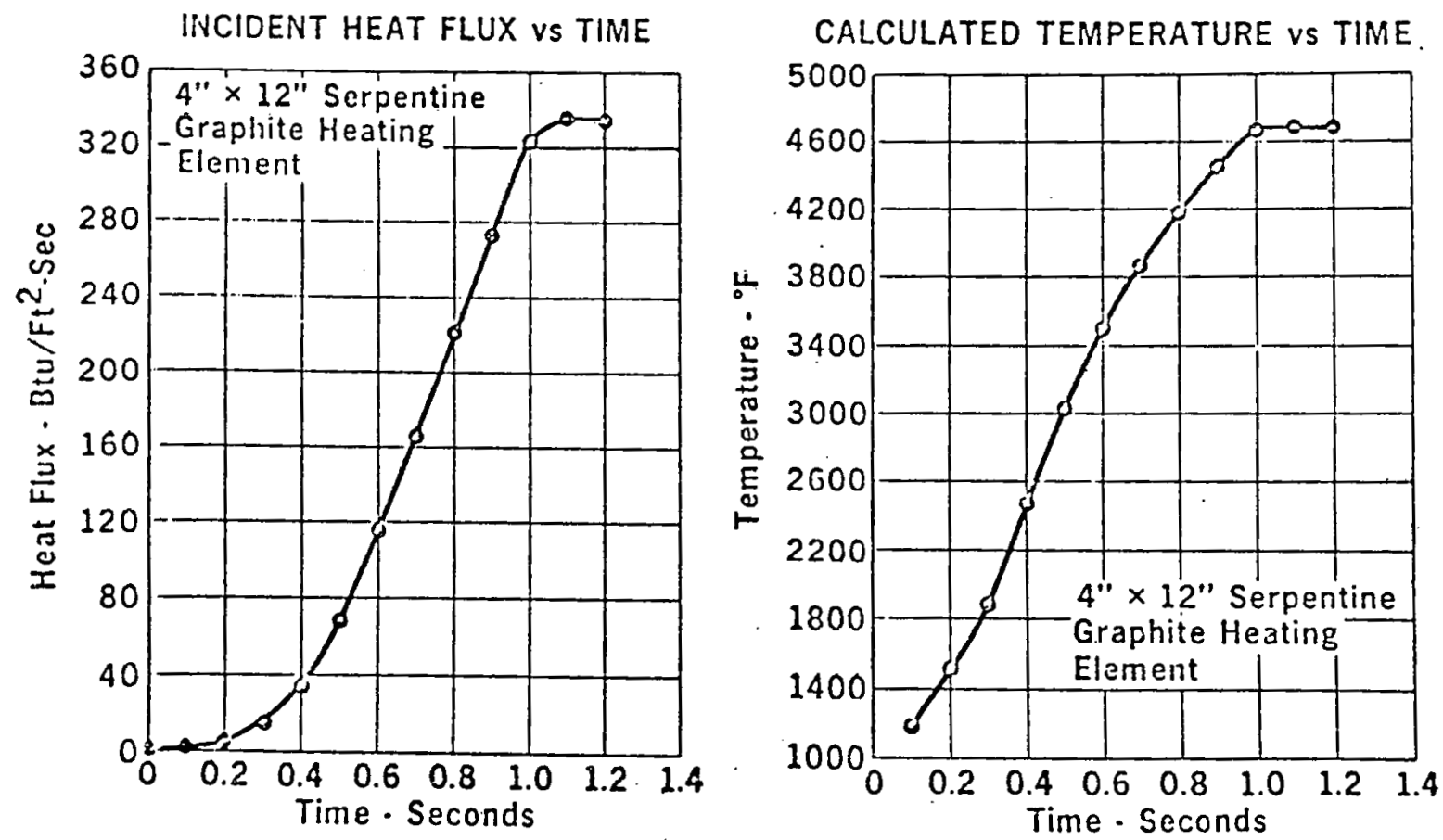

Figure 22. Typical Response 


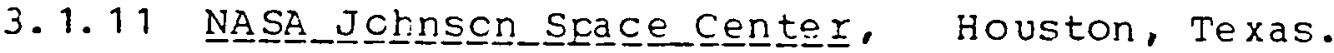

A 5 Mie radiant heat facility is being developed at the INASA J.S.C. to facilitate the heavy test commitment cf the space shuttle program. The Erimary objective for these tests, and therefore the configuration of the facility, is to simulate: the reentry conditicns for the space shuttle vehicle relative to pressure and temperature. Details and descriptions were not available at publication time for these facilities. However, the heating units and controls are being fabricated by McDonnell Douglas (see section 3.1.10). This facility is heavily committed to the space shuttle program with testing scheduled thrcugh Nov. - Dec. 1975. It might then be available on an "as available" Lasis. 


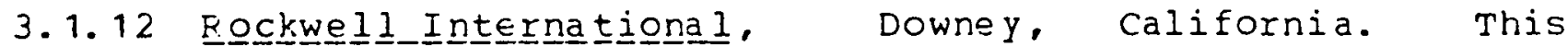
facility of $5 \mathrm{Mh}$ capacity, is owned by NASA J. S. C. and is also neavily committed to the space shuttle program and wculd be available on an "as available" basis upon NASP approval. Det ails and description of this facility were not available at publication time. 


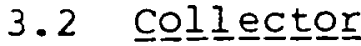

There does not seem to be any unique facility requirements for the engineering and develogment testing for the collector subsystem. In general, participating contractors will have adequate facilities for conducting tests employing an optical bench, laser grid, or Foucault tests as well as those tests for the structure and tracking mechanisms. is the sun is the Frototype energy source, there is little reason to employ any other except for optical bench tests on the reflective surfaces. There are a variety of techniques in the literature which can be used to measure mirror surface accuracy. Generally, no exotic testing facility is required. Where long distances are needed, any unobstructed line of sight may be usable.

The following facilities are identified to illustrate the general capabilities for flat or long focal length mirrcrs. 


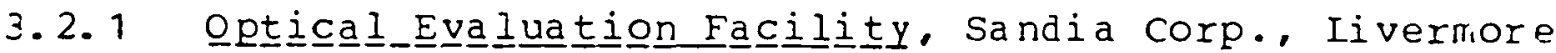

This facility consists of two basic units: (1) the optical bench, ccnsisting of a laser/grid setup, and (2) a fullgimbaled mount, constructed to test tracking and contrcl systems and to evaluate mirrors. Figure 23 schematically represents the laser/grid test setup. A laser is used to project a grid pattern on the mirror being tested and the reflected image is photographed. Eigures 24 and 25 show images produced by the pcint loading technique and the spin casting process (parabolic). The full-gimbaled mount is shown in Figure 26 .

closese locop sensor. A simple but effective sensor is available which consists cf a tube that sits in the reflected solar radiation and is aligned with the aperture of the cavity. $A$ pin hole or lens at the low end of the tube directs or fccuses the reflected image of the sun onto four photocells located at the upper end of the tube. Figure 27 shows this quad photocell configuration.

Photocells 1 and 3 operate together into a differential operational amplifier to provide a vertical error signal. Photocelis 2 and 4 operate similarly to froduce a horizontal error signal. The error signals drive the respective axis of the mirror until the reflected image falls onto the center of the guad photocell. As long as the sensor tube is correctly aligned. the reflected radiation will be froperly redirected.

Either photovoltaic or photoresistive cells work equally well. Photoresistive cells presently are aboct five times less expensive, however. When a signal is generated on one of the photovoltaic cells, it is amplified and drives the servo mechanism on the affropriate axis. If photoresistive cells are used, the pairs operate as a balanced bridge. As the resistance goes down on the cell with the most light, a signal is sent to change the corresponding mirror axis.

An in-line sensor with both a wide angle acquisition and a precision tracking sensor incorporated into a single tube has been built and tested. A hole is located in the center of the wide angle quad photocell so that as the image of the sun moves in on the wide angle sensor, it eventually goes through the hole and falls onto the second quad photocell which allows precise mirror adjustment. The two quad photocells operate electrically in parallel.

Testing. To test tracking accuracy, a gimbaled mount was built on which a 6-foot diameter mirror can be mounted. The axes of the mount are driven by AC motors running through a 75,000:1 gear ratio. Tracking accuracy was monitored using a target made of 48 adjustable photocells located in a cross pattern. Preliminary testing indicates the mount tracks within \pm 2 minutes.

Contact: Mr. Tom D. Erumleve (415) 455-2941 MI. Alen Skinrood (415) 455-2501

Reference: SAND 74-8017 "Status REFort on High Temcerature sclar Energy system", sept 1974 


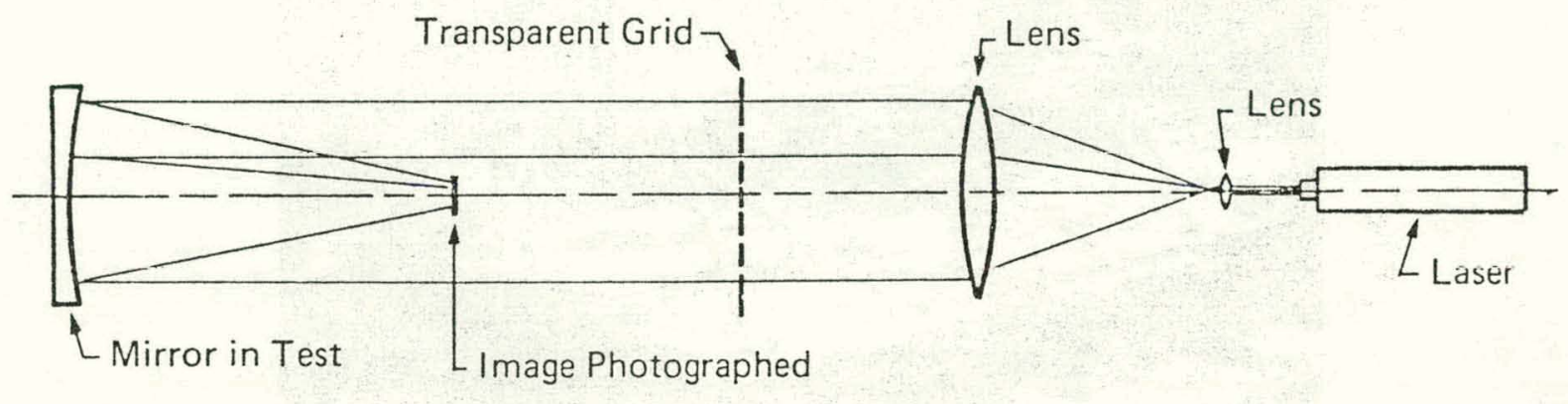

Figure 23. Mirror Test Setup

$\begin{array}{lll}\text { Figure 24. } & \begin{array}{l}\text { Image of point- Figure 25. } \\ \text { Loaded Mirror }\end{array} & \text { Image of centrifuqally } \\ \text { Cast Epoxy Mirror }\end{array}$ 


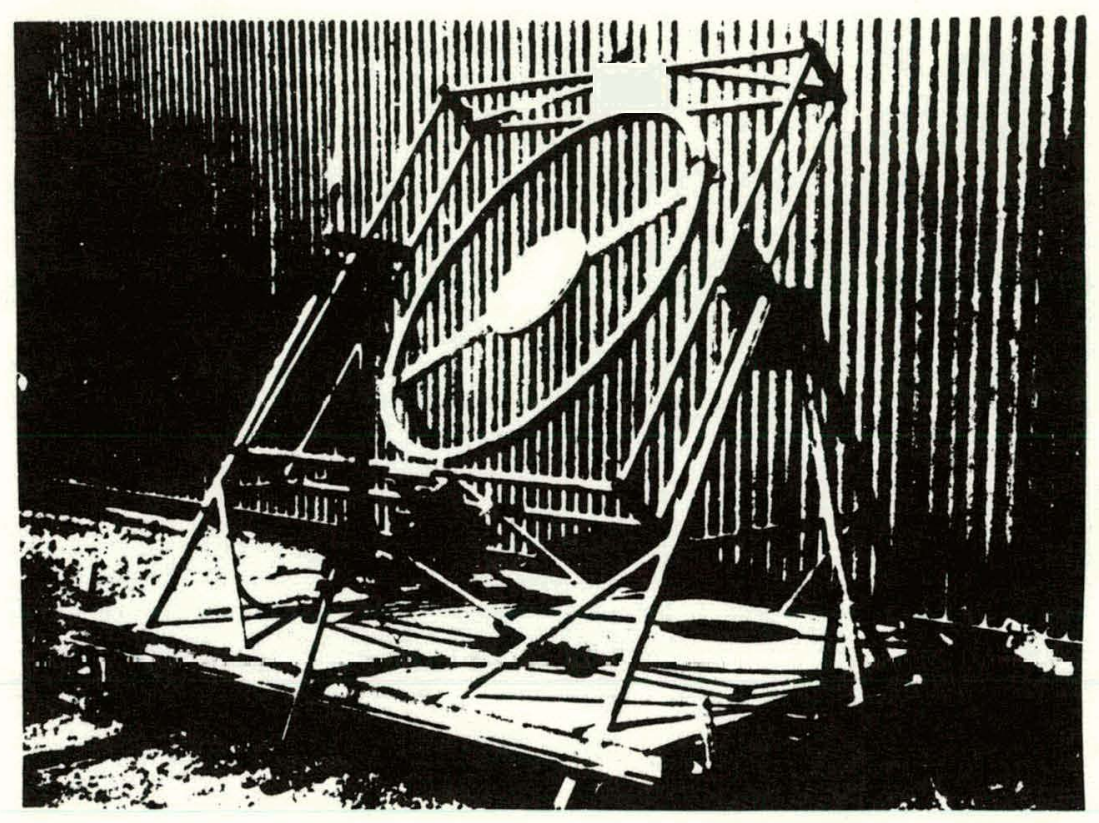

Figure 26. Full Gimbaled Nount

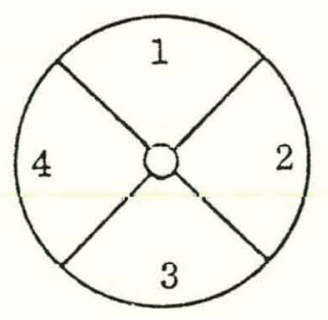

Figure 27. Quad Photocell configuration 


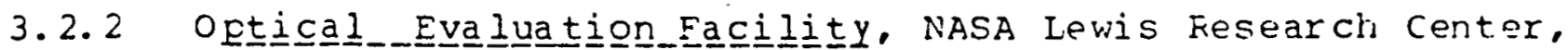
cleveland, Ohio.

The unique feature of this facility is their solar concentrator insfection device. This device is particularly useful in inspecting relatively short focal length mirrcrs such as their 20 ft diameter, 9 ft focal length parabolic concentrator. When testing the surface accuracy cf their collimator mirrcrs of 61 meter radius, Foucault tests were conducted. The solar concentrator inspection device does not seem to be applicable to the measurement of long focal length or flat mirrors such as are being considered for the ccllector subsystem heliostats. No other unique equipment or tests were identified at this facility which would be of particular use for testing the ccllector subsystem components.

Contact: Mr. John L. Pollock (216) 433-4000 x354

Reference: Report 20-Foot Solar Concentrator Inspection NASA TMX-68042 "400 Kilowatt Argon ArC Lamp for Solar Simulation", pp $4 \varepsilon 5$. 


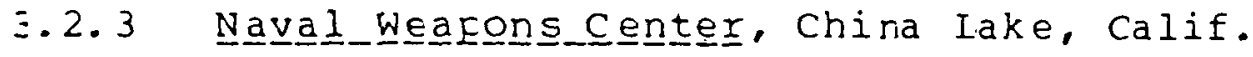

OPTICAL_E EVEIUA instruments to measure non-normal incidence transmittance, normal and non-normal incidence reflectance, attenuated total $r \in f l e c t i o n$, and scattering from mirrors and windows.

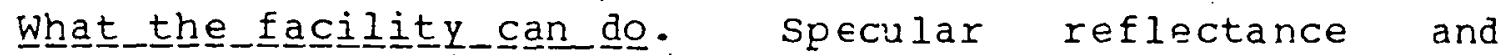
transmittance at normal incidence can be measured from the vacuum ultraviolet to the intermediate infrared. Specular reflectance can be measured as a function of angle of incidence in the ultraviolet and visible spectral regions, and attenuated total $r \in f l e c t i o n$ can be measured in the visible and infrared. Scattering from optical surfaces can be measured as a function of scattering angle or as total hemispherical scattering from the ultraviolet to the infrared; the roughness of a surface can be calculated from the scattering measurements. The accuracy of all measurements is at least 10 times better than is possible with ccmmercially available instruments.

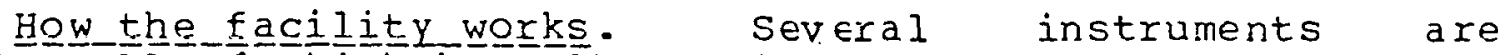
a vailable, all of which have been built at Michelson Laboratory. freedom from systematic errors. In all types of measurements light of a single wavelength falls on the sample, and the amount reflected, transmitted, or scattered is determined. (Figure 28).

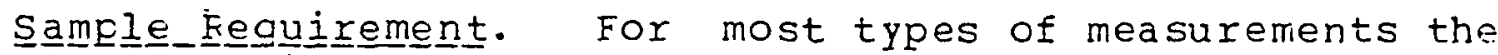
samples should be in the form of disks 1.520 inches in diameter and 0.25 to 0.375 inch thick, with one surface flat to within a wavelength of light and polished to a mirror finish. For scme of the reflectance and scattering measurements, the samples can be actual mirrors up to 40 centimeters in diameter with radii of curvature larger than 11.5 centimeters.

Processing $T$ ime. Processing time is variable, depending on the type of measurement desired. In most cases measurements take about 15 minutes per data foint after the initial adjustments have been made.

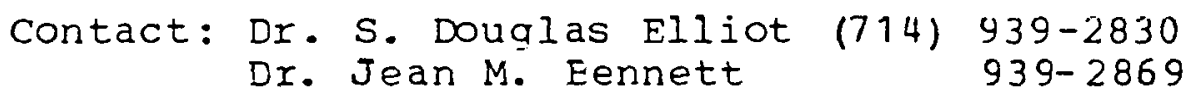




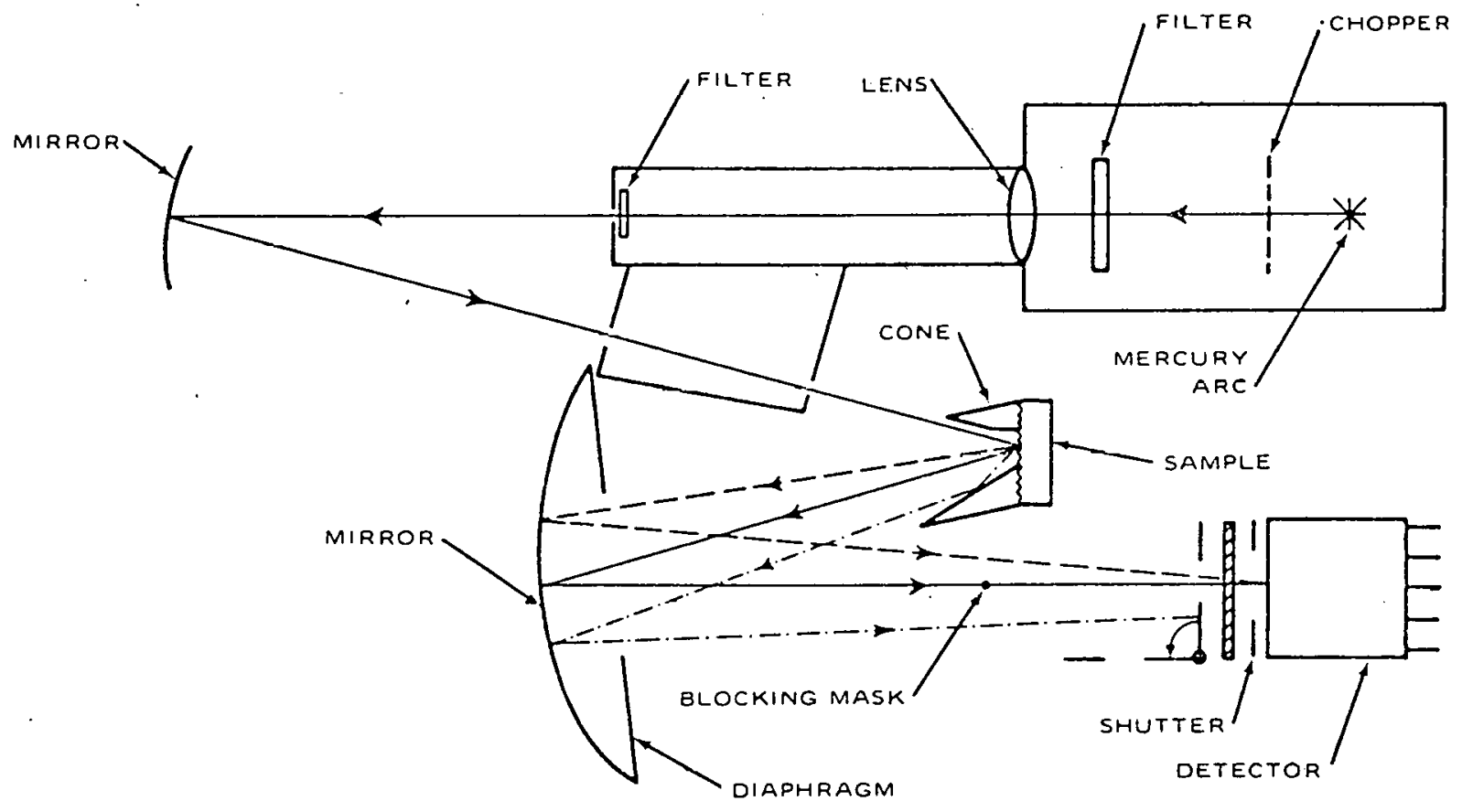

Figure 28. Schematic Diagram of an Apparatus to Measure scattering from a Sample

(The specularly reflected beam follows the solid line and the scattered light is represented by the dashed lines.) 
3.3 Thermal_stçrage. Due to the unique requirements for Thermal storage for the proposed Solar Thermal central Feceiver I'ower system, only the exsisting facilities at the sandia labcratories, Livermore have been described as these descriptions were readily available. Other facilities may or may not be available to meet the needs of specific subsystem concepts. These facilities are being developed as a result of prior interests of the A. E. C. in this field of research. 


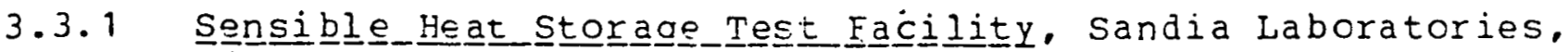
Iivermore, Calif.

The sensible Heat storage Test Facility is made up of the following three circuits:

(1) Heater or collector simulator systems.

(2) Storage systems.

(3) Load simulator systems.

Instrumentation is included to obtain data at critical points throughout the system. This will allow measurement of the efficiency of the system and verification of the proper operation of specific components. In addition, control eguipment is included for autcratic operation of the system.

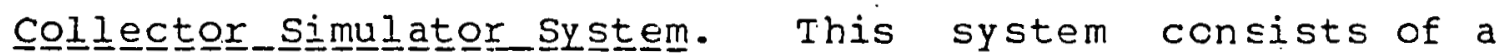
heater with pump, heat exchanger and normal safety equipment. The heat transfer fluid, Monsanto Therminal 66, can be used at temperatures up tc $\in 50$ degrees $F$. A temperature control valve regulates a heat by-pass system. In addition, there are flow meters and a number of visual and recording instrumenes for temperature and pressure.

Stograge_-system. The storage system consists of the heat exchanger, a stcrage tank, two fumps, and an evaporator tank. This system also has the reguired safety features. At present it $i s$ designed to use (1) water at 450 degrees $F$ and 450 Fsi. (2) Therminal $E \epsilon$ at 550 degrees $F$ for the storage fluid. This system has two temperature control valves which control two heat bypass circuits. There are also flow meters and visual and $r \in$ cording temperature and Fressure indicators. In addition, the storage tanks can use the thermocline principal and has $2 \epsilon$ thermocouples fCr recording the storage temperature at different heights from the bottom of the tank. Two diffusers are used for supplying and $r \in m c v i n g$ fluid from the tank without disturbing the thermocline. The instrumentation in this system is sufficient to $x \in$ cord the amcunt of energy at critical points plus the capability of monitoring the operation of the diffusers. (See Figures 29 and 30 ).

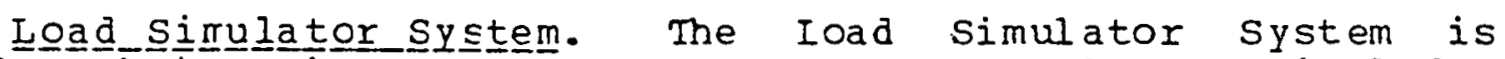
designed to bring city water to an evaporator tank. It includes instrumentation to measure the efficiency of the heat transfer and the changing of cold water to steam. This system will have programmed loads that will call for output from the storage tank.

General ${ }_{\text {- }}$ comments. This facility is now being assembled and will be operational in the spring of 1975. If desired, the Fresent storage system can be replaced with other storage systems for test and evaluation. Maximum operating temperatures and materials and fluid compatibility would have to be examined.

components in the system are:

Healer: Fulton Fultemp Thermal fluid Heater No. $10 \mathrm{~T}$ output $\quad=326,000$ Btu/hr 
Opr. Temp - 600 degrees $F \max$

Opr. Press - 75 psi

Fuel - No. 2 Fuel Oil

Heater Pumf:

Power $-7.5 \mathrm{HP}$
Capacity $-10 \mathrm{GPM}$

Heat Exchanger:

Cross Flow construction

Q - $330,000 \mathrm{Btu} / \mathrm{hr}$

Heat Transfer Oil - 550 to 450 degrees $F$

Storage water - 350 to 450 degrees $F$

Storage Tank:

Volume - 1775 galions

working fressure - 450 psi

Wall thickness - 1 inch

Heat capacity $\quad-1,250,000$ Btu at 100 deg.

Insulation - (1) wall, super insulation and vacuum

(2) top and bottom glass wool klanket

Storage Pumps:

(2) RSE Centrifugal Type CFK 300

Power - $3 \mathrm{HP}$

Capacity - 10 GPM

Evaporator Tank:

Cross Flcw construction

$Q \quad-160,000$ Btu/hr

Storage water -450 to 350 degrees $F$

supply water - 55 to 220 degrees F

contact: Mr. A. C. Skinrood (415) 455-2501

Mr. T. D. Erumleve (415) 455-2941

Reference: Sandia Laboratories Memc Jan 7, 1975

R. A. Milby to A. C. Skinrood

"Sensible Heat storage Test Facility"

SLL- 73-0.263

"Sensible Heat Storage in Iiquids"

T. D. Rrumleve, July 1974 


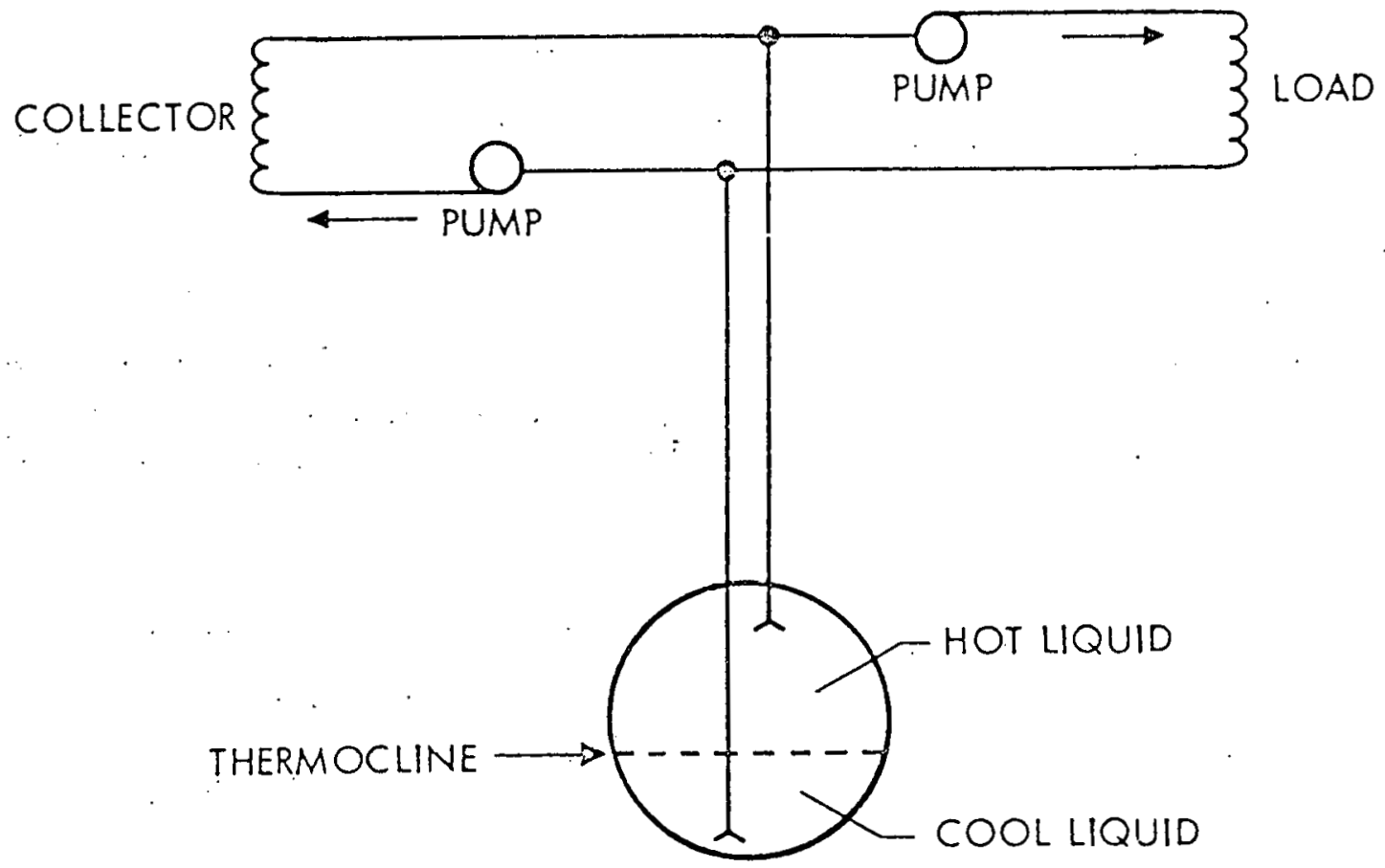

Figure 29. Sensible Heat Energy Storage system Schematic

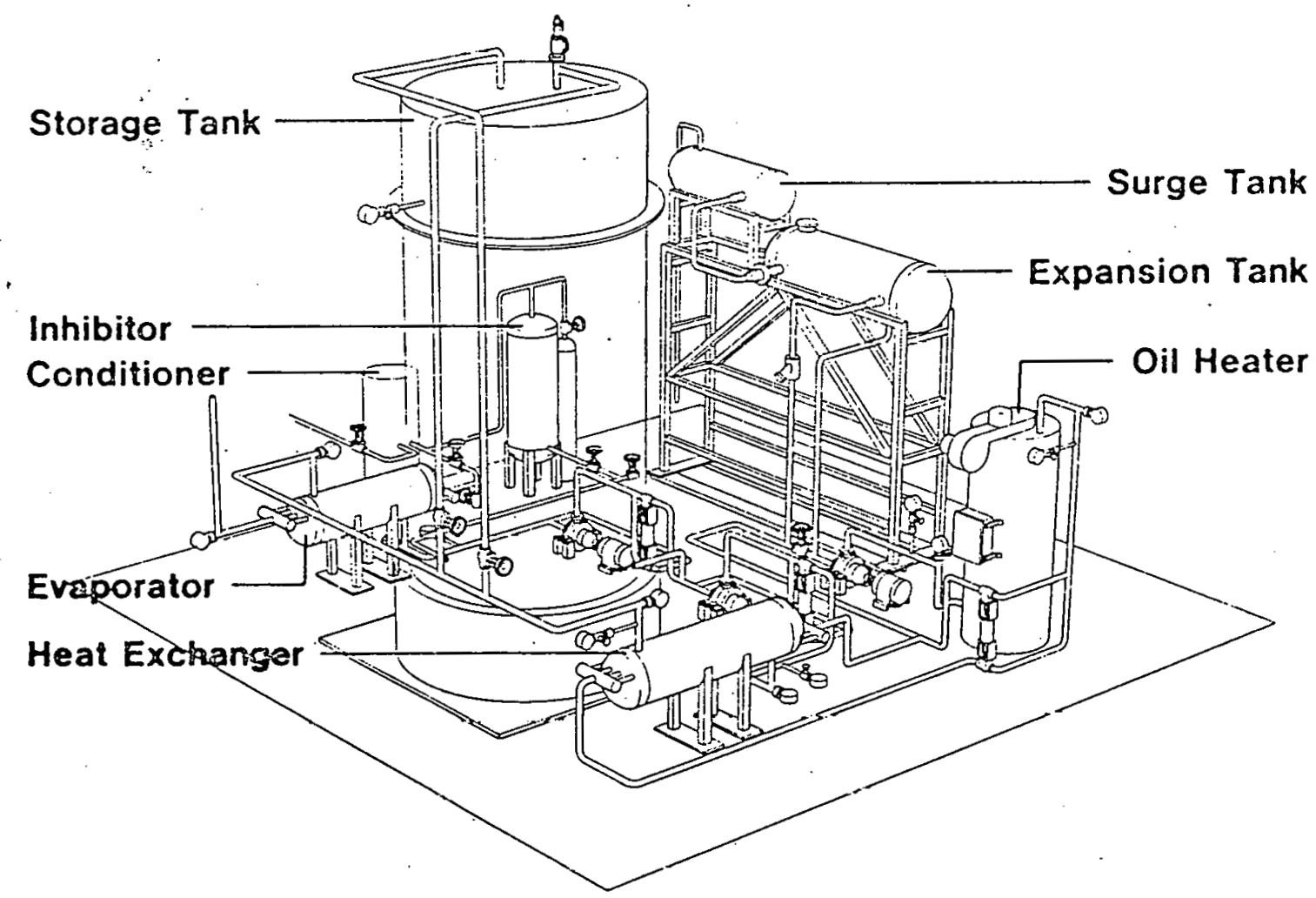

Figure 30. Experimental Test Facility sensible Heat storage of Iiquids 


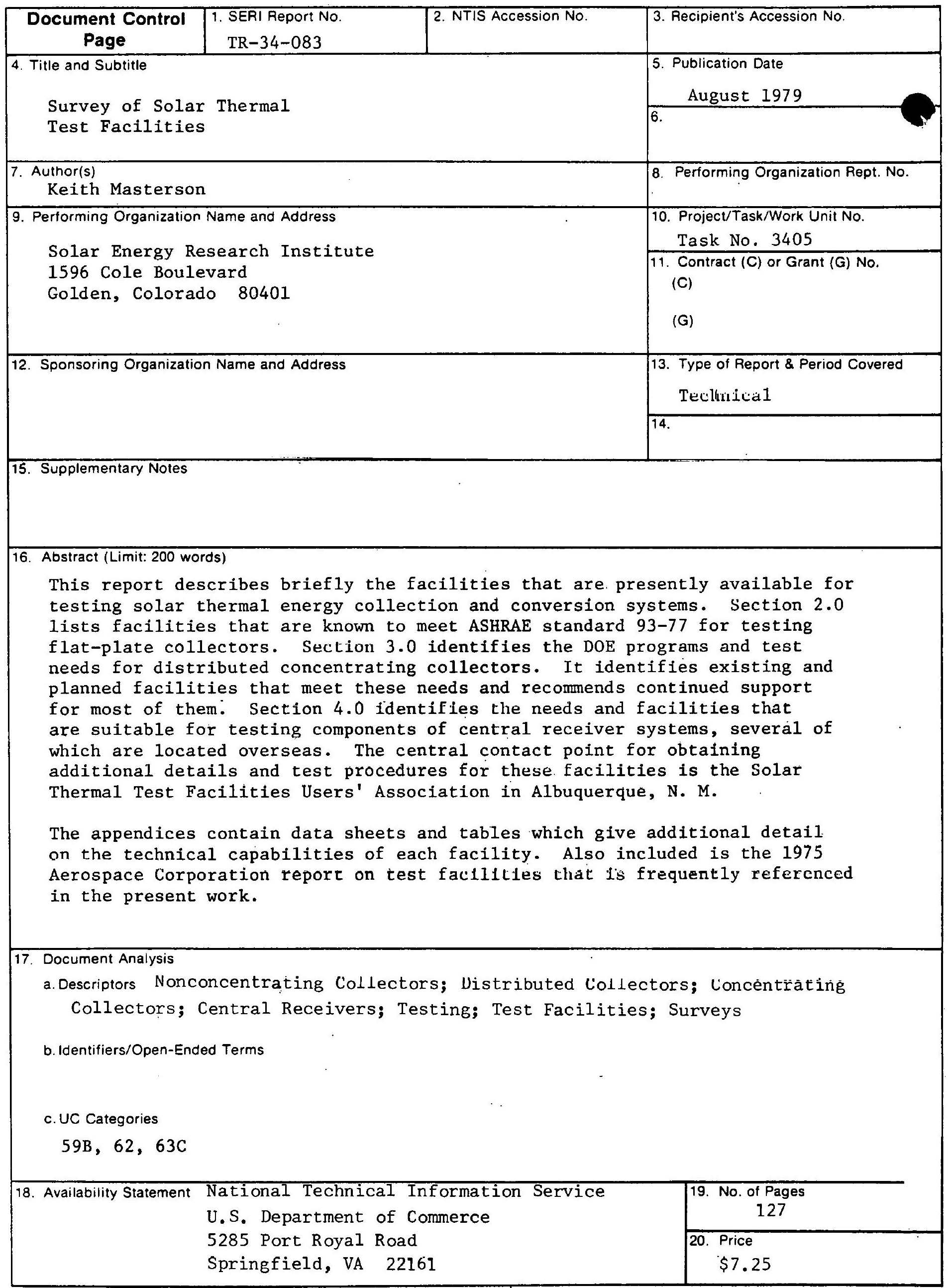

